University of Louisville

ThinkIR: The University of Louisville's Institutional Repository

Electronic Theses and Dissertations

1934

\title{
Diplomacy at the outbreak of the World War.
}

Earl Robertson Martin 1890-1984

University of Louisville

Follow this and additional works at: https://ir.library.louisville.edu/etd

Part of the Diplomatic History Commons, and the European History Commons

\section{Recommended Citation}

Martin, Earl Robertson 1890-1984, "Diplomacy at the outbreak of the World War." (1934). Electronic Theses and Dissertations. Paper 1832.

https://doi.org/10.18297/etd/1832

This Master's Thesis is brought to you for free and open access by ThinkIR: The University of Louisville's Institutional Repository. It has been accepted for inclusion in Electronic Theses and Dissertations by an authorized administrator of ThinkIR: The University of Louisville's Institutional Repository. This title appears here courtesy of the author, who has retained all other copyrights. For more information, please contact thinkir@louisville.edu. 


\title{
unIvengix or zoorsving
}

\author{
DtPromex \\ AT The oowbrank \\ OF THE WORED WAR.
}

\author{
A Dlesertation \\ suludted to the rachet

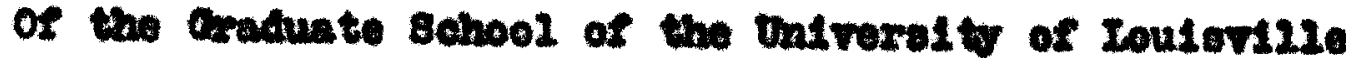 \\ In Partial Mariziment of the \\ Bequlromente Sar the Degree \\ Or raeter of Ante
}

Departwent of Aletory

4.

Dave Robarteon Iartin

Toar

2084 
A Polltioal mirder.

\section{Chapter II}

Mrgo-slav Jationazlan. .....................7

\section{Chapter III}

The Dual Jonarohy Indangered.................16

Gerble napter IT

Sorbla mut de Destroyed........................24

\section{Chapter $\mathbf{Y}$}

The Austrian ontimatum to serbia.................30

The oltime tum vorks....................

Chapter VI

The fusetan Hoblz1zetion.....................53

Onapter VII

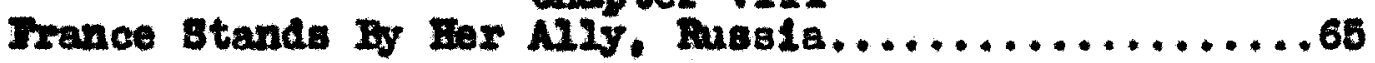

Onapter IX

Diplomacy Fal1s..........................75

Chapter $x$

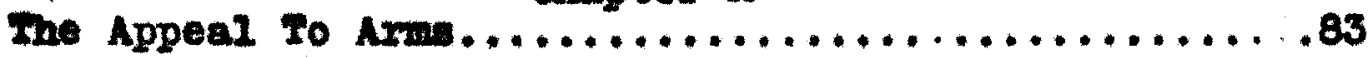

Chapter $\mathbf{x}$

Ingland and Belgium Inter The Vorld Var...........92

Japan supporte Ingland.

Chapter XII

self Interest Loade Italy To JoIn intente............27

Chapter XIV

Gapter $x I v \ldots \ldots \ldots \ldots \ldots \ldots 142$ 
Enapter 1

A Polftleal rurdar 


\section{anter I}

\section{A Polltear Invier}

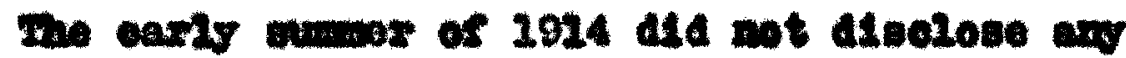

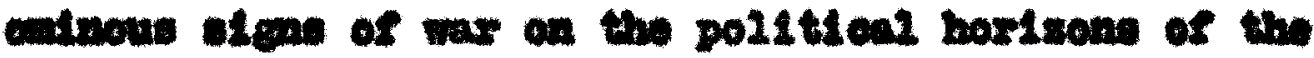

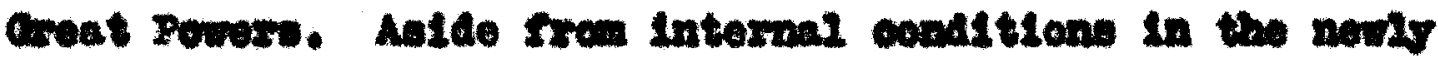

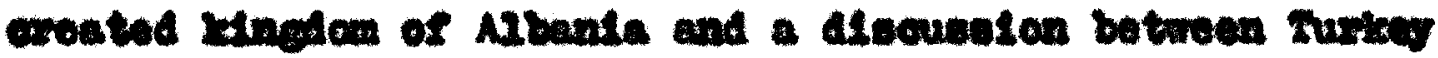

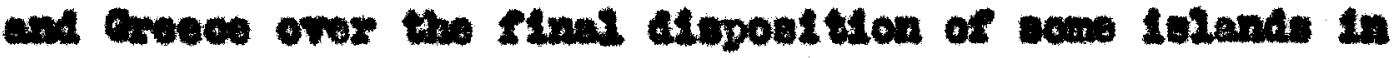
the Aogean, therre wore no stoxn ozoude that encgeated the tarnedo-21le epproach of var.

However, In the aldet of oumarative pesoe, tro bhote were flred that waxe hourd areund the worla". Oas kl12d Aroblulso Franots Berdinand, holr apparent to the throne of Anstria-nungasy: the other fatally Injurod his Wte. Bophie Caotok. Bophte, Bophe, do not die", satd

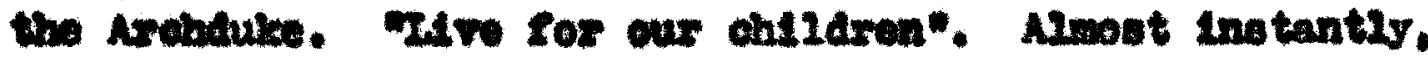
howerver, weth died. The apoaseln, Prinolp, was taken away to sal. 1

The oft of serrjero, Doenta, was the Loeation of the under. Etroe 1908 Anstriempunary had been in comple to coater 2 of the provinoe of Bomia. It wae cundar

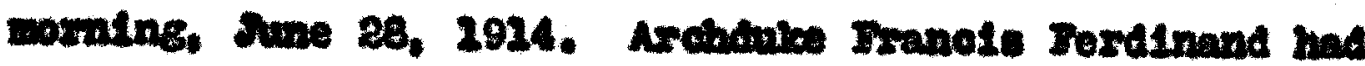
owa in an offictal capacity on an inopeotion tour to

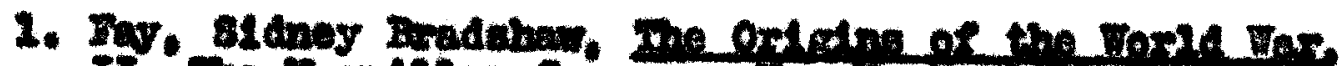
II. The Tachilian Coman, wow rork, 1030, D.126, oueting conrad, IV pp, 19-22.

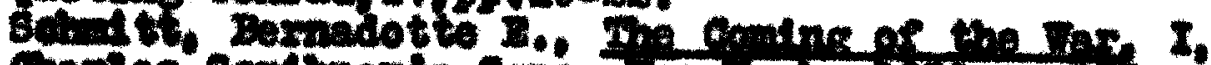

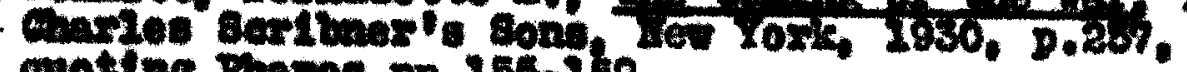
quotine Pansos, pp,165-269.

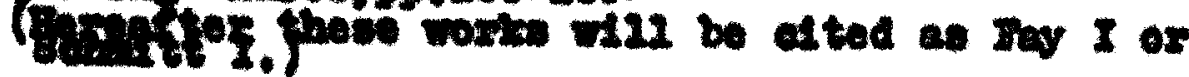


attend oertain milltary maocurres. A minoteon yoar old Doentan of theen of regoter extraction k11204 htm.

The studeat of hotory in 1924 could correothy

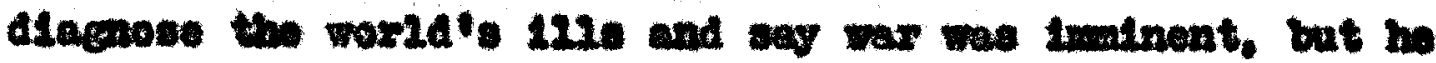
knew not when nor where it would begin. Dat the two shoto were the torches that set moat of Burope ablasen for at thin four welk a declaration of war ma been sent, follomed up ahortiy at other cealarstions, until the zareest part of the world had jolnod the sray.

Prinolp had never wot Franote Fordinand, but the latter was ooton of the Hajeburge. The faot that rravole Jordimand wa a Bapoburg was sufflotent; therofore, Princtp ale $\mathrm{hin}$.

Wahingten and Coxmallie wero not pexsonal enenter, but they fought each other to a riniah in the Revolutlonary War. The one cestred freedon from Eneland; the other mated eleser ralations with the srolre. In a way the coloniots and the serblane had glentlar motives. Rovolutionary sentinont in Bosnla favored separation of thelr prowinoe frow Austria; the Arehalke reprevented a eovermment that wented to koep Bosita at all hasards.

macmuch as Iranols Mordinand ropresented und ty

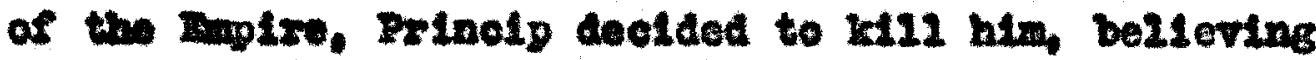
that so doing the indepondence of his oountry would be foatered, The asmasetn, too, had been Infuenced by thove veom be constdered martors to the cause of Jugoelar freedom. Oas of those was zherajitch, a Nersegovinian. In 1910 the Iatter anot eive time at the covernor and then opeodi2y oonstited mulotde. Ine covernor went untouched, 
but bo otrued the Jagoviave to the depthe wan be kloked

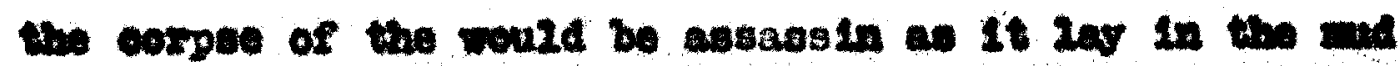

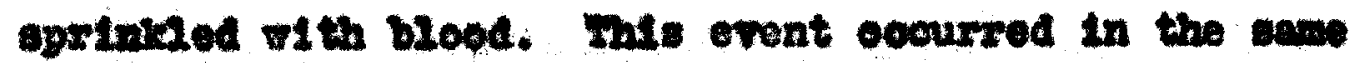
tom whare the two chote of 111 fated meary vere later 81red. The youth were eapeolaliy inflamed by the corodnorts

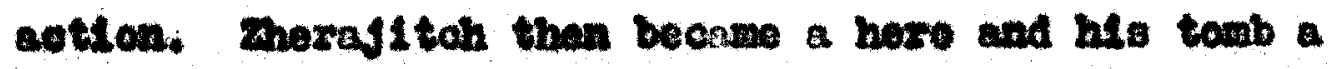

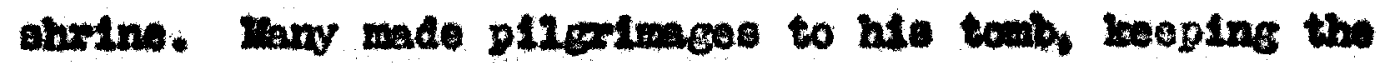

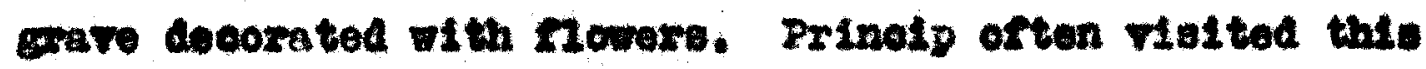
towb for reflection and Inepiration. It is wate that wen the day before be fired the fatal ohote that ho decorated the erave and owore by it that his band hould whoet true the noxt day." ${ }^{2}$ It wa not otrnnge, perhape, that a mo

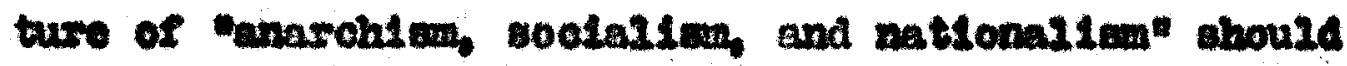
Influence minds of acwe younk won. Suoh a marty as Theragltoh would have a tremondoub infinenoe, poycholog $10 a 2 y .3$

No coubt the authorities in Bomis were norvous. Between 2909 and 2924, 266 persons were trled for hith oximes acalnst the tate. Of these, the majorlty were round oul2ty. Hay Bosnians thought, it vecused, that mrancis Ferdinand was etrondy opposed to Jeoslar nationallam." Woreover, sane of the youths wibhed to be heroes. Coneequenthy. they were on the lookout for possibliltiee of klline any of the hicher coverment offiolalo of Voma. The aebassins were also cestrous of revenge.

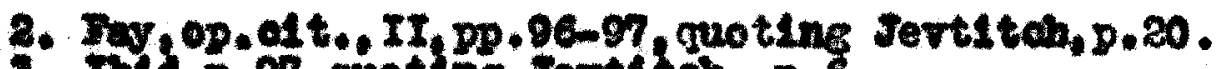

3. ma, p.97, quoting sertitah, D.6.

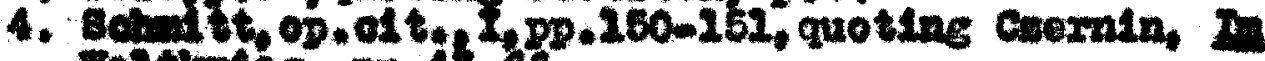
thathe pD.4366. 


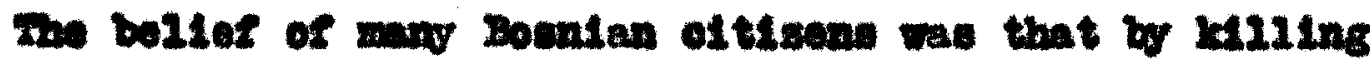
the Ialr to the Furene thay wovid get renceanoe and aleo

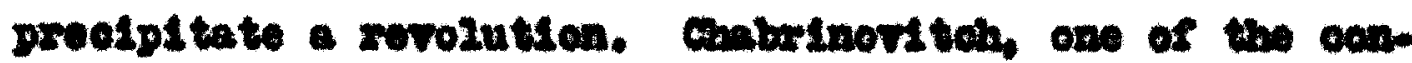

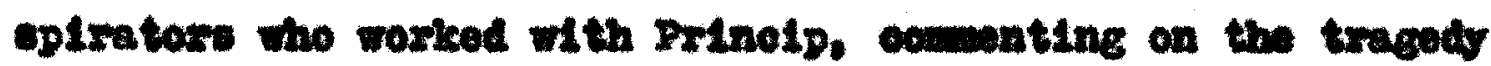
easd, I megardod sevenge as a holy cuty of a moral ot thILed man and I. thexefore, planned to tate pengeanes.....".

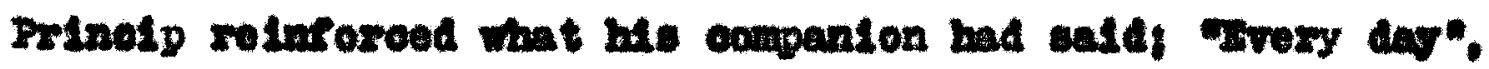
protented the maxderex, of hich treacon trial. Irery dey 18 went worwe with our people. I li2lod hin and I an not sorxy". He ceolared that Mrenole Iexdlnand wa Interested In wion and to prevont it man 11 ves met be secrifleod. For Frinolp was afraid thet the Bils to the morose would attempt to estabiloh a tripartite union anong the Hagrere of mungary and the Jugontave of Bosnia and Herseronis. When anced if be favored this tripartite union.

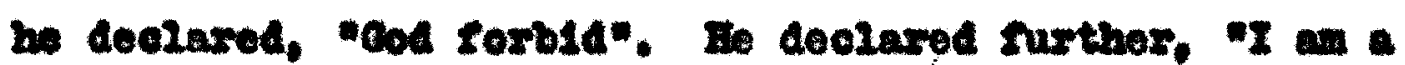
natlonallet". Whe far as serbla is oonoerned, it is hor enty to free uo as Italy rreed hor Itallens".

Twis the assaselne hoped to remove the Indivicuad whon they besleved to be the koy man to tholr 1dea of progrees, Fith him out of the way. they ceolded they could

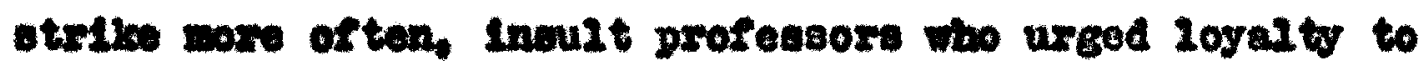
the Implxe, stir up dieturbances at the playlne of the Iational Anthen, and hurl Imvectives at those who bad chop elons witten in cexmen.

As the Hatr Procusptive and his rife went through

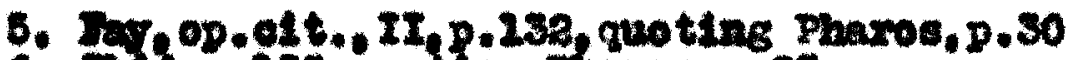

6. ISt, p.23s, quoting Fharoo, p.23. 


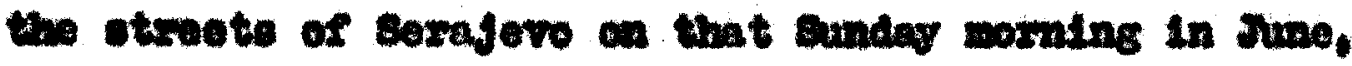
2024, etren ooneplratos analted him with bembe or pletols. It dees not secu etronge that the rist tore ald not egoape. As the oar bearing the perty peased by the point where

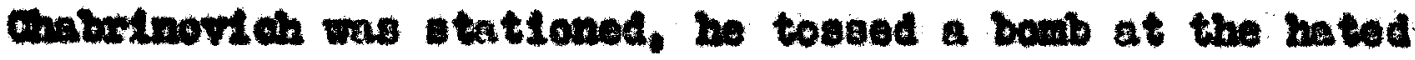
palx. The obatrfour we the instrubent of death coning and pat on epeed. The boub elthor hit on the rear of the car and bounced off or was thrown back of the ear by 1 to would bo riotln. At any zate the bowb oxploded, wounded a Leutement-colonel in the seoond oar, and injured seroral

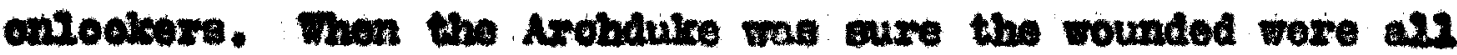

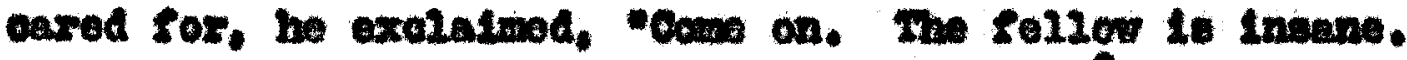
centhem, 2ot we prooced with our progras".

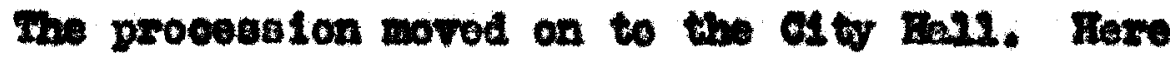

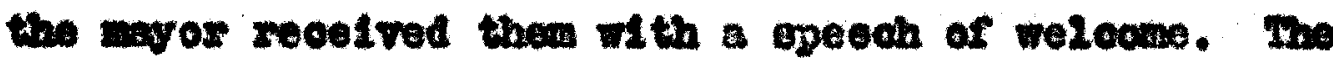

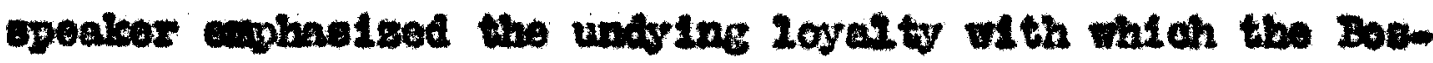
Alene ereated hin. Thereupon, the Helx deolarod, Hough of that". What! I malce you a ristt and you reeetve wo

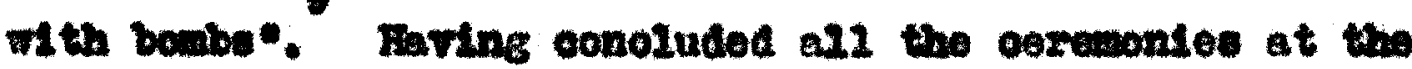
64 EnI2. the procesetion moved on. It was reported to Franole Fexdinand that the bowb thrower had been apprebondod. At this, the Helr eald, Thane hin as soon as you cen os Vempe wII aond him a decoration". 10 atounder- tanding about the route to be taken caused the Arohurite 8 car to slow up at the fatal corner. It was 21,30 A,II. when

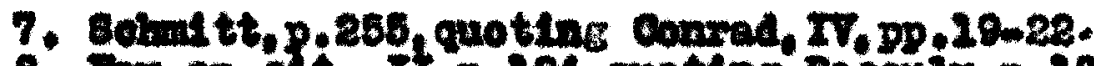

8. $74.00 .016 .$, It, p.224, quoting Regouly. D. 283 .

9. Ibla p.226, quotine Reogaly, D.184.

20. scinft, op,att., $, 0,266$. 
the plot was excouted. Frinolp flred two ahote as the chanffeur, monentarily oonfueed about his direotlond, broucht his ear to a stop.

\section{2}

A woprage that sam dey from serajero to a

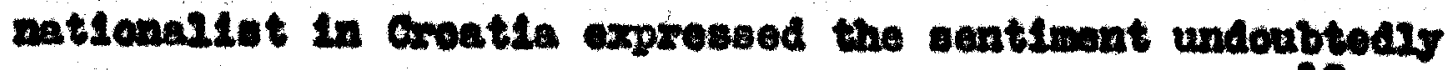
of way southolavet Woth hoxes well Alopesed of".

Iong after those evente had oceurred, the paseera-by at the cormer of XIng Peter street and the oua wotlced wormen riveting a bronse tablet to the warl of a atore. Ht thie plooe". they read, Cavell Prinolp prealained Itberty swe $28,1914 *$.

Prodalmed Ilbertot" Fol2 could orents similar to the aseaseination inoplre the terse expresalon, ILberty. what oxtwes are ocunittod in thy namol".

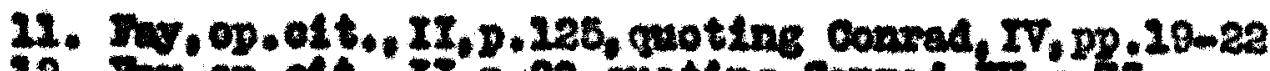

22. Jav, OD, aft, II, D,80, geioting conxad $T, 0.75$

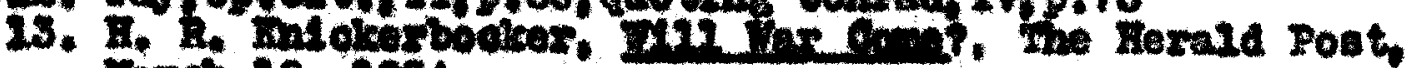
Eroh 22, 2934 
Chapter II

Jugo-SLev Nationalism 


\section{Gapter II \\ Tugo-8Lar IntLonalle}

The vave of natfoandism that had swept over Europe enguled the 8outh-elavs too. Bomale and Barzecorthe wose imbabltants were Iargely slatio wented to bo a part of a Jugo-nar natlon. Berbla, too, was interestod In comblning all the peoplo of the seme raolal characterLetios into one natlon. Sezbla, moreover, did not hate an outlet to the bea. In order to get comerce on a larger bests, and be able adeguately to protoot herself from attacies frum the sea, Serbla mes most dealrous of getting accese to the Adrlatio. Iot only did sorbla want the torritory of the Bognians and Herzegovintane beoause of the erographieal ralue of these torritorles, but also because the people thowase zres were kinomen and friendy.

Fowever. Anetrlamfingary had coelent on the same Iand and the same peoples, and naturaily wanted the Adriatle Sea so har own epectel property. Obriougly tho was Intereated in abeiking the ambitions of hox slavio nolghbor to the south of her.

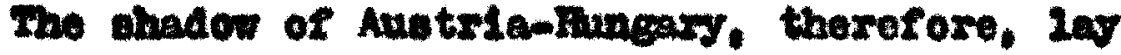

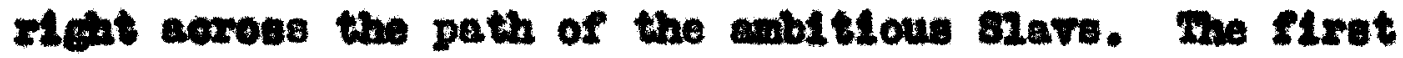
blow to Bexblan nationalien oave in 2878 whon Austria-nungary was Invited by the Powers of surope "to ocoupl" the provinces of Bosule and Beraecorina in order that the peace of Burope aldet be malntalnod. The Coneress of Berlin st this sano 
the set serbla free from all control by the Porte. In another thirty years (2908), the weoond blow 9011 to the advantage of Austrla-mungary whoh, at that time, actually annexed the provinces of Bosnla and Herzegorina. The shadow had become a reall ty and Serbla"s dream was ahattered. Sexbla however did not deepeir. She turned to Russia, her protector at other times, but this power was wholly unprepared for a Huropean war in 1908, having juet previously completed the disastrous Ausso-Japanese war. So Cuohor. one of the leaders of the Fussian Duma, advised Serbla that when Russla had completely reorganized her armo then she would have her check up with Austria-hungary. "Do not begin any wax now". sald the Duma member, "for this would be your oulo1de; conceal your purposes, and make ready; the day of your joy w111 come".

The Czar a few day later relterated the mentiment of the Duma member when he sald, "the serbian sicy was orerming with black clouds". He declared that the defeat of Russla would zuin "slardom".

The discussion with Russia, however, was not the only card in Serbla's hand. For Inmedlately after the annexation by the Dual Monarchy of the Slavic provinces an organization was effected in Belgrade whlch meant mioh to Serbla, Austria-hungary, and the peace of the world. This

1. Hazen, Charles Downer, Hurope Since 1815, Henry Holt and Company, Wew Tork, 1910, D. 626.

2. Fay, op. o1t.. I, pp. 384-385, quoting report of Kasutitoh in Deuteghland sohnidig, p. 112.

3. Tb1d., pp. 385, quoting Bogltoheritoh, pp. 150-151. 
was the organization of Harodine Odbrans or Yational Defense. Maturally, branches were eatablished in Bosnia and Berzegovina, the discontented slav territorsee of Austria-Iungary. Other branches were established throughout Serbla. Frovided the olty or diatriot was oufflolentiy 1arge, a commlttee was appolnted to serve as connective Iinks with the Belgrade headquarters. If the population was emall, a confidential man was appointed to keep in contact 1 th the headquarters of the organlation. Hore than 400 committees existed.

The Farodne odbrana opposed to the annexation of the slav provinces Austria-mungary. It did not hesitate to axy that Austria-mungary was the ereatest onewy of Berbia. It preached serbian 1deallam, fostered education, and farored Improved conditions of byglene and temperance. since war with the Hapsburg monarchy seemed ineritable, the organization trained the young men to be able to thror bombs effectively in order that bridges and raliways could be quickly and effectively cemolished. Jaturally it was easy for propaganda of any nature to be broadcast through the medium of spies that oould easily be sent through countries inhabited by 82avio peoples.

The "Onderground Ra11road" stem, utilized somewhat effectively in the United Statea before the Civ1l War. was perhaps not more effective in assisting slaves to the

4. Schmett, op.01t.. I, p. 181, quoting Union or Death

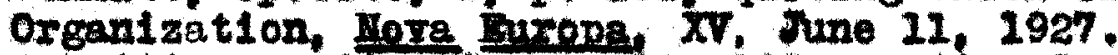

5. Sohnt tt, op.c1t., $1, \mathrm{pp} \cdot 182-183$, quoting surkotion,

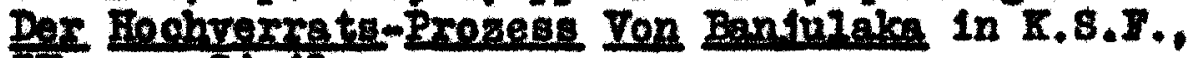
IX, pp. 34-4I. 


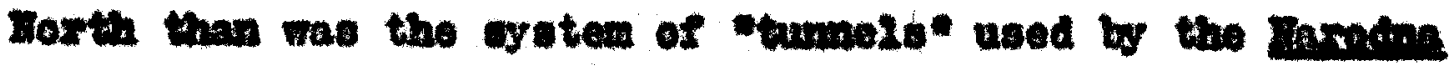
2ativen in sending books, nowopaper olippinge, and other propagands Into Downi. For the cake of broad and room, for the saice of the fundemental oenentlala of culture and trade, the freelng of the conquered serblan territorteo and thotr untion with serbla are necessary to contlomen, trademon, and peavents altre*.

Frofessor solmitt declares that a member of the

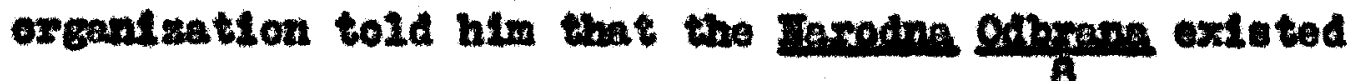
largely on paper and that ilttie was done.

In oplte of the deciaration that $11 t t 10$ was done. Prinetp, the murderer of Mranole Derdinand, deolared at he trial that he had been a momber of the ratlonal Defonwe woolety and as wou had been elven woney.

oust three years arter the forming of the aroch

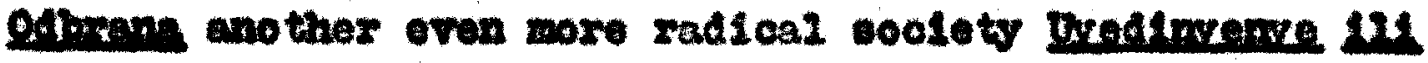
But Dnton ox Dasth was organlzed. It was uoualy reforred

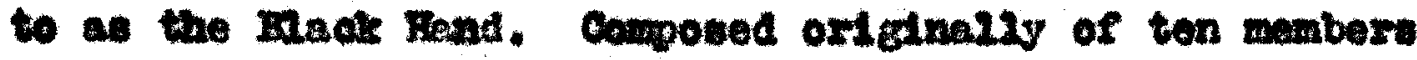
thic soolety had ite beedquarters in Belgrede. Ito alm vas to unt te all Serbe (Art. I) preferring terrolst we thode to Intelleotual propacanda". (Art. 2) It plamed to organise revolutlonary moverents in all territories where Berbo 21red. It w121 wee eroxy meane arallable to combat the adverearles of the natlonal 1doa". (Art. 4)

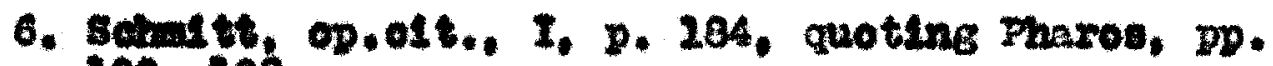
200, 208.

7. Solind to, op, o1t, I, 9.82.

8. Iotd. D. 281, gootmote, D. 293.

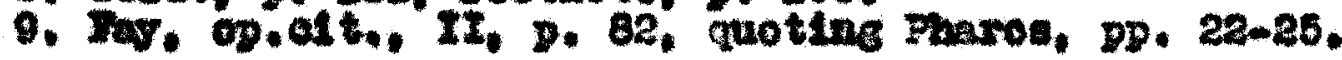


Onky a courageous Indivioual would joln the Dnton or Dasth. He realy aurrenhered bie "persenalsty" (Art. 30); was bound to absoluto obedience to the

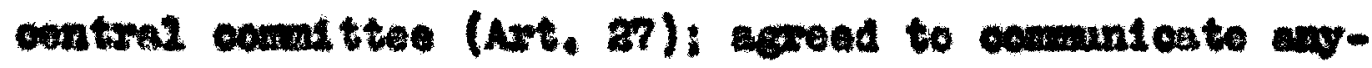
thing of interest to hadquarters (Art. 20): and pleded he ow $21 f 0$ for the preper conduct of ans nomber he witht recowmand (Art, 24). To add to the mettedera the mambere had wubers and wore unlanorn to each other poreonally (Art. 25). ${ }^{10}$ It if no wonder that the deolazation was

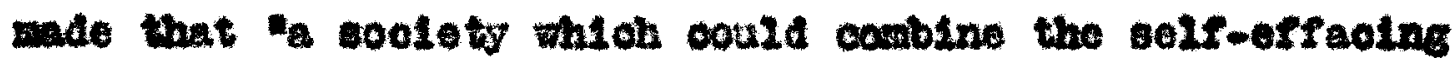
20yelty of the Jesulte, the suthieas opirit of the Buesien

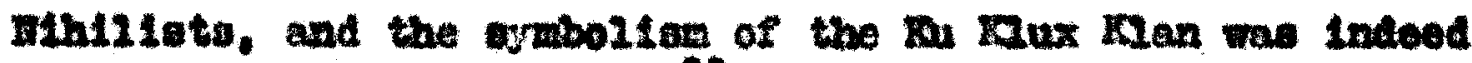
a noteworthy organization."

Bereral cross-ourrents existed in Boenla and Herregovina, not the least of whloh was that of religlon. About 625,000 Greak Orthodost, 1argely 3erbo; 612,000 Whamedans Alvided cans sorbe and Murke; and 442,000 Rowan Catholles, Iargely Grodtb. Wexe in the provinees. Tith a grimalne of Jows, Protestants, and erpeies, the total mulver approximated $I_{, 200,000}$ in population. In a 2arge weasure the Creok Orthodox poyulation I1kod the serbians; the Romen Oathollo loyartles were Alvided botween thesr relations of th cultural Austrie on the one hand and tholf dealre for Berblan Nationalien on the other. The Eohanedano were for the wost part favorable to Franels

20. 8elat tt, 09, 04t, I, p. 101, guoting Poportoh,

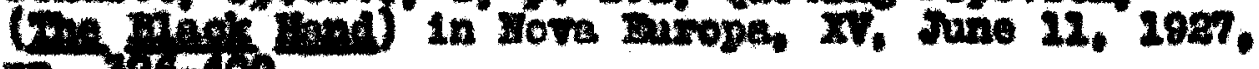
DP. 3060100 .

11. Selnt tt, op.ett., p. 293 . 
Joseph.

\section{2}

Other currents running against the barrier of Austro-Hungarian force were; those of the youth of Bosula who were opposed to Hapsburg treatment; the hope for unity anong the Jugo-slavs; the writings of anarchists, and the propaganda introduced from serbia.

Daturally the young Bosntans looked to Berbia as a source of supply for their energles and activities. Hany of them frequent2y went to Belerade where they breathed the free air so different from the atmosphere of the Fapiburgs. Three of the youths who were in the plot to k11I the helr apparent to the Hapsburg throne had visited in the serbian capital.

Another leader apeaks, wakes people up, and agaln disappears 11ke a shedor as if he were swallowed up by the carth feeling himself followed by the footfells of Austrian agents anong whom were some serblans also". "Then the Zagreb Erbobran publ1shed the news in Jarch 1914 that Irancis Jerdinand would visit serajevo on June 28 , it stirred the passions of the Slars. For this was a day of national mourning due to the fact that at the battle of Kogsovo in 1389 the Serbian state had been overthrown. It appeared to some of the revolutionary group as if the Arohduke's Fisit were deeigned as an insult. Without knowing that Prinoip and others had already declded to

12. Fay, op.o1t.. II, p. 93, quoting Augtro-Bungarlen Consua of 1910.

13. 19, 0p.01t.. Ir, p. 100, quoting Pharos, pp. 22-24.

14. Jay, op,clt.. II, p. 97, quoting Jertitah, p. 6. 
I11 the nelr-apparent they sert the nomepaper olipplne to Chabrinovich, one of the revolntioniets in Beigrade. whout cownont save the word "greoting".

Imediately Cobrinovion began the diseneston of the wrier with Prinolp. Crabesh, another revolutiondet, read the elfppling. Hoetling his two friende, he oxpresed His Indigration at the propoeed riest of the Arohalice. The three dected to to the deed. They were not long in gotting ald. All preoticed shooting for somo the.

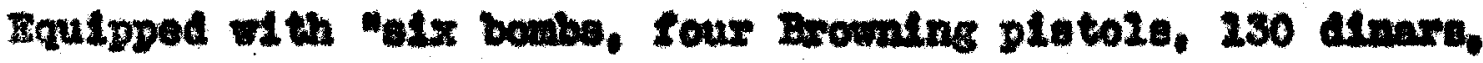
a road map of Bominta". ane poloon, and a note to the offietale at the frontier. they oot out in lay to barajero. The toumer" worited perseotiy. Princtp oent telogran to ono of tho Hack Hand" 20adors, "The marrlage W12 tale place suncay. send funds".

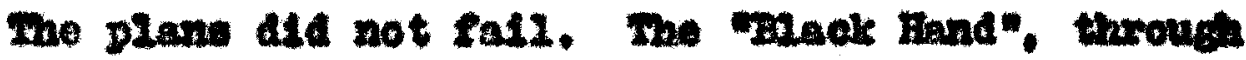
1te Internetional oporation, sddod another axime to ito 110t. Those menbers folt that tho Powere had not atven then s square deal at tho Congress of Berisn. Bubsis had told Bexble to wat 4111 a moxe conventent sencon. Dut the rovoluthonlata were undling to walt. Mathonallem had owept through thatr ranke as wind weope a pratrite $21 \times 0$. To the revelutiontate, necassity lnow no lam". It was a guestion of tunt te or alo\%. they thought. Mo in 2878 nusicey arrenderod torritory for the oreanination of sarble.

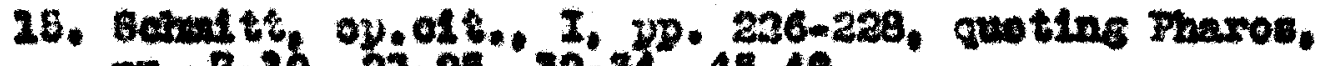
PQ. 7-10, 23-25, 32-34, $45-48$.

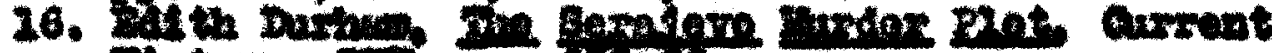

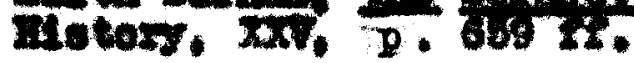




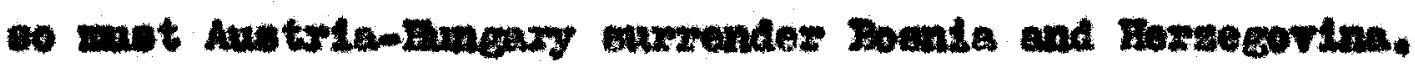

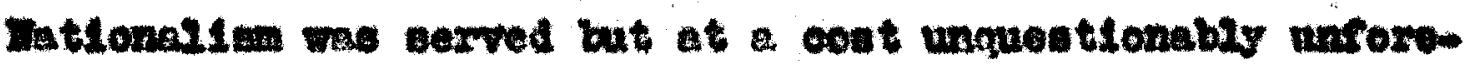
ceen by the Back Band, Serrita, and Mutatemangary. 
Chapter III

The Dual Ionarely Indangered 


\section{Chapter III}

The Dual Ionarahy Findangered

When the new of the death of Irancle Ferdinand was dellvered to Branols Joseph, he uttered these words, "Was I not to be apared even thia?" How upon blow had descended upon the aged monarch. Many tragedies had boset the relgns of the Hapsburgs. Francls Joseph's brother, Haximilian, had, against the advioe of some, gone to Mexico to be Muperor in the land of the Hontezumas. Ho had been shot by the Lexlcans, and his wifo became Insane. His son fudolph, so rumor bas it, aled from aulolde. Hla nephew beoame ingane and kl11ed his guardian. An anarohlat near the end of the nineteenth century k1120d the Bnprese IIzabeth. Otto, another brother, added to the gorrow of the Imperor when he began to lead an Immoral I1fe.

When Francls Ferdinand in the early nineties used to rialt at the home of the Archduke Irederlok and the Archduchess Isabella at Pressburg, the Archducal pair had Flolons of their daughter as the Impress. An accident revealed that they were deluded. One summer day after a tennis match, Franois Ferdinand had forgotten to take his watch when he changed clothes. The watch was brought to the Archduchess by a servant. She could not resist opening the 2ocket, expeoting to see the ploture of her daughter.

2. Jay, op.olt., II, p. 29, quoting Margutt1, p. 239.

2. Ib1d., $I$, p. 29, quoting Kareutt1, p. 139 . 
Instead she the 21keness of Bophle Chotek one of her 2adles-in-7ralting. It mattered not that sophle Chotek wa a countegs in her own right, belonging to a czech fancy of long tradtion. Irabella's areams orashed Imediate2y, and almost as quickly the countess was ordered from the house. Irancis Ferdinand declared he would warry sophle, and the mperor declared he would not. A coupromise was effected, however, by Francis Joseph granting his nephew the right to contraot a morganatio marrlage.

W1 th this as a background, it was emell wonder that there was not much emotion in eridence when the bodles of the Berajevo assessination arrived at Vienna. It is eren the more eas12y understood why the head of the Dual Honerohy wondered why he "was not spared" that indignity. The honors to the dead were ferf, and the last rites were not those befitting a position which Francls Ferdinand had ocoupled. For the moperor did not I1ke the helr preanumtIve, and the court would not tolerate the Puahess of Hohenberg whom they I1ked to call Sophie Chotek. The body of the nephew wes in a plain casket with the full insignia, however, of his rank about him. On the casket that held the body of his wife, a pals of glores and a black fan were placed indieating the past rank of the Duchess. The noperor sent no flowers, and Imvited very few people to the funeral. He even excluded the children of the Archduke

3. Fay, op.cit., II, pp. 28-30, quoting IIk1 tsoh-Boulies, $p .26 \mathrm{ft}$. 
from attending the funeral of their parents. Only 150 exeat nobles attended.

Even the German ralser did not come, for he had been advised by the German consul at Serajevo that assassins wight be present in Vienna. The Kaiser sent a personal note to the puperor saying that he wel giving up his journey "with a heary heart and deep grief. Tor the benefit of the pubi1c, information was given out that the Talser wa 212 from lumbago. The Britibh Ambassedor thought the brevity of the services for the dead, which lasted only flfteen minutes, was out of consideration for the age of the Homer. Hich discussion about the apparent slight to the ceparted ovidently occurred. For the goverment deemed it necessary to explain that a precedent had already been established in the cases of the arrival at night of the bodies of the mapress Elizabeth and Archduke Rudolph, and that as much military display had been given to the late Arohduke as to the former cases.

4. Schnitt, op.c1t.. I, pp. 280-28I, quoting steed, I, pp. 402-403.

5. Outibreak of The Dorla Max (Kautsky Documents). German Documents coliected by Karl Kauteks, oxford UnIvera1ty Prees, Iew York, 1924, telegram, July I, 1914, \#o. 6A, p. 59. Hereafter referred to as Santisy Documents or $\mathrm{K}$. Z.

6. Tbid.. p. 60, telegram 107, July 2, 1914.

7. Cooch and Temperley. British Doguments On the ortetps of the Far. Vo1. M i ihe orbreak of var king Stationery office, tondon, 1926, 10. 26, p. 18. Herearter referred to as Bxitioh Dommentis or E. D.

8. Ibid.. Io. 34, p. 26 .

9. Ibld., עo. 37, p. 29. 
Frencls Joseph was among the last of his age. How changed conditions were in 1830 when he was born! In that year a wave of revolutions awept over Burope menaolng the absolute govermments of the world. In 1914 the aged monarch was among the last of the near absolute rulers. Maturaliy, ho was determined to maintain his Huplre for hls ouccossors. It was a diffeult task. mumerous peoples lited within the contines of hts mupire and the nationalities apread out on a map of Austria-hungary resembled the patches of a crawy quilt. The tendency for pooples of the same race, hablts, and customs to live under the ame Nag and govern themBelres had been growing. Both Italy and cermany had each united their peoples under their reapective flags. But Francls Joseph could not accept that sort of polltical philosophy. He was opposed to nationallam because, onoe ho accepted that polloy, his mpire would fall apart into a number of pleces. Had he accepted a nationalistio pollcy. Boania, Herzegovina, and Croatla would most Iikely have Indicated their desire to join Serbla. Serblan 1rredent1om, as has been shown, called for the union with Serbla of the southern provinoes of Austriamingary. The meror had been watching this national1atio movement for some time.

At the time of the eventful tragedy of SeraJero, Francis Joseph sent an autographed letter to the Kalser, his al2y. He expressed regret that Filhelm II 
was unable to attend the funeral at Vema. 20 He alse, under the stress of the moment expressed a few political sentiments. The researches made concerning the moloody deed of Berajevo"..."Indicate", he said, "that 1 it is the result of a well organlzed plot". The alm of these Pan glarists is to weaken the Triple Allianoe and shatter unglise", he urote.

Then the aged monarch put out a feezer. He ouggested that a nev Belloan Ieague should be created under the control of the Triple Alliance in order to encourage nulgaria and attract Roumania back into tronger tles of Irtendehlp with the members of the Triple NILiance. Conoluding, he expressed the conviction "that a conclilation between serbla and us is out of the question... Wh11e this center of criminal agitation continues unpunished In Belgrade".

Fery intereating, too, was a memolr" acoompanying the letter whi oh had been completed a day or two before the assassination. In it some observations had been made by the Austrla-Hungarian Forelgn minister. Count Berahtold, regarding the oonditions in the Balkan peninoula in the yeara 2912-1913. On the whole, the count thought conditions were somewhat favorable to the ropire and the Triple Alliance. Albania had been created and

10. Austrian Red Dook officlal Files Pertaining To pre var hatory, Part I. Geo. Nlien and Onwin,

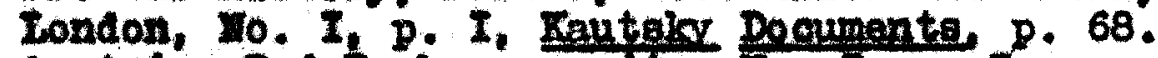
11. Angtrlan Red Book op.cIt., Ho. I. D. I. 12. 2rid, D. 3 . 
1t would, according to Berchtold, be in a position whin a few years to be of some effootive milltary absibtance. This otate, too, would offset the growth of serbla. It seened erident that mulgarla had at lavt ewekened from "her hopotic dream" and would not in the future be dominated by Russia.

Along wi th these advantages, the count. ppeaking for the goverment, suggested some disadvantages. Firet of all, it wes distreaging that Turkey had almost been dxiven out of Inxope. Should Serbia and Nontenegro unite, which was possible, it would be detrimental to Aus tria-Hungary's interests. Fussia and France had teken measures, ho said, to consolidate thelr advantages and minimize or modify the measures they did not like". - The alliance between Pursta and France... wast, In its last consequences", Berchtold sald, be of an offendive nature." On the other hand... the character of the Iriple alliance lo purely defensive," sald the Austrian Foreign minister. It was ovident, ho said. that the Alplomacy of Russta and Irance would urge the Alliance of Bulgarla and Serbla. Rounanta. according to the count, wes not as frlendiy as formeris and woula beax watching.

At the close of the "memolr" a fow statements were made after the assassination had ocourred. Mustria-

23. Austrian Rod pook, op.c1t., I, pp. 3-13; … D. pp. 70-77. The teble of contents of the Iustrian Red Book indicates that the copy of the Hemolr" ras a rouch draft. The Kautely Documents, Mo. 14. $p .70$ Indicate all ght modifloations in the phreiling over the document in the A. R. B. Hereafter referred to as A. R. B. 
Hangary", says the report, has always shown good w111 and Irlendiness to bring about tolerable relations with serbla". since these efforts have been in valn, the gotermment mut "In the ruture look to the tenaclous, 1rreconcliable, and aggressive enemt ty of serbla". The report concluded with an announcement of pollcy. Who government mat selze the threads, which 1 ts enemies are wearing into a net orer 1 to head, with a strong hand and tear them onoe for a12". 14

The two Broups of Powers known as the Triple NIIance and Triple Fintente faced each other in 2914. Brents in the forty-1ive year period preceding the outbreak of the Vorld War were ominous for the peace of Burope. Among these events were the formetion of the Iriple Allience, the Anglo-Russtan reconciliation and the Triple Intente. The tro orlses in Morocoo in 1905 and 1911 respeotively, had aroused the Cermans and Irench. The Baykan er1ses of 2908-1909 and 2912-2913 -t1rred the fussians and Austrians. 18 the treaty of Bucharest slened August 19, 2923 was not very favorable to Aurtria. Serbla was at last given territory on the Adrlatic and her increase in land was relatively large. Roumanla wa glven territory, Dugarla loot territory

14. Anstrian Red Eook op.o1t., I. p. 13. Hauteky p. If Gires substantially the same material but phrased differentiy.

15. Henouvin, PLerre, the Impediate Ortating of the Var. June 28-Ausast 4 19X Translated by wheodore carenell the, Yale Oniversity Press, Jew Haven, 1928, pp. 10-21. 
and naturally wa Indlenant. 16 Auatria did not Iike the treaty of Bucharest. Inlo was indiceted by Berchtold when he sald:

- . Serbla, whose pollcy has for many yeara been hostile towards Austria-mingary and otands entirely under Russian Influenoe, has galned both in popuLation and territory wioh more than it expected. Its territorial nelehborhood to Montenegro and the visible growth of the Idea of a Greater Serbia makes an agsrandisement achleved by the unlon of th Hontenegro seem a not unilkely event." 17

At last Austrla seemed to partialiy understand the activities of the Ferodns adbrang and the Mack Pand. She sew that these organizationa would cause her mach trouble unleas a way oould be found to stop them.

Serbia, as has been mentioned in a previous chapter, had set out to undte all south slave under her control. May Berbs, Serbo-Croats, and Slovenes I1ved In Austria-fungary. Berbia was anxious to annex the territory where they 1ired. The revolutionists would achlere unificstion by falr means or foul.

Austria-fingary was equaliy determined that Serbia should not unite all the South slars. The 1asue was joined. It seemed plausible to say that to prevent this unity the fupire mast apply the same principle as Solplo used long ago when he sald, "Carthago delends

16. Cooke, Henry and Stickney, Edith P. Reading In European Intermational zall Since 1879. peace of Lucharest", August 10, 1913, Herper and Brothers, Iew Tork, 1931, pp. 243-247.

17. Anatrian Red Book, I, P. 3 . 
eat." It eppeared at this juneture to be a I1fe and death struggle. Would Austria-mungary use the marder of the Archduke an ocossion to check the ambitious 8lave? The next chapter w111 disclose the angwer. 
Gopter IV

Boxbla nuat Dontrabod 


\section{Chapter IV \\ Serbla Must Be Bectroyed}

The Austrians recelved the news of the assassination with anger. It was nocessary in Vienna to protect the Serbian Legation from a mob. Miltary peoplo and the upper classes Ielt, generally, that the time had come to have a reckoning $w 1$ th serbla. The sentiment of publio opinion begen to move toward war.

Before serajevo, many offlotala at Vienne belleved that sowething ought to be done to trengthen the old furpire, After the assassination they were aure they were right. It was necessary, they belleved, to construet aditional buttresses for the mplre." Frenols Joseph, degiring to end his days in peace, was afrald conditions in Serbla were becoming Intolerable. The meror and King had not been ouccessful in his wars, and, quite naturally, in hlo declining years he was reluctant to start a new war. Mevertheless, he sald to the German Ambssaador. "I see a very dark future". Ho bellered that nothing could be gained by being kind to the Serbians. The Ambasaador declared, My heror w121 stand behind every f1rm determination arrived at by Austria-Fungary". Fear the olose of the Interv1ew the

1. Tay, op.clt., II, p. 186, quoting Conred, IV, pp. 31 \&f. 
aged monarch in speaking of the death of a famous Itallan general sald, Mrerybody is dy ing around me; it 18 too sad".

General Conrad, Auvtrian Chlef of Staff. favored wer. He belleved that it mas necessary to draw the aword against Serbia....". He had foreseen the necessity of war for some time and had frequently urged the Government to f1ght. Conrad now urged Berchtold to atrike. In the last analysis, Berohtold seemed to be the key man. He had declared July 2 , in no uncertain terms that the "gulf between Austria and serbla is beyond bridging over"." The Austrian Forelen Inister, therefore, declded that he would use the orlwe of Serajevo as the cagug bell1. He would cheak the threatened fusion of Serbla and Iontenegro, and save Albenta. When the Jugoslavs were taken care of, the dangers in the bouth would disappear. Berchtold, there. fore, adopted the enggestion of Conrad, and decided that serbla must be destroyed.

Count Berchtold, however, had to move with caution. He mist be sure of pubzlc opinion, Tisza of Hungary, the mperor, and $\nabla 12$ heim II. A year before,

2. Techtrschly to Bethmann, telegram, July 2, K. D.. op.01t.. I0. II, Pp. 64-66.

3. Tay, op.olt.. II, p. 185, quoting Conrad, IV, p. 31. 4. Austrlan Red Book op.c1t.. I, p. 13. 
Bethnann had warned Austria against attempting to gobble up serbla. However, conslderable water had gone over the dam within the year, and Berohtold hoped to be able to gain Cermany's approval and assistance In his proposed Berblan venture. For the falsor had been extremely friendiy to Jrancl Joseph and the Archduke.

Wilheim was enjoying a short racation at KIe1, and while aboard his yacht, June 28, he noticed a Il launch approaching. He vaved 1t eway, but the admiral aboard eignalled that he had a commulcation. Tolding a paper in a clgarette oase he pitched it aboard the Ealser's yocht. It was the news of the fatal report from serajero. The Ralser turned pale as he read the note and ordered his yacht to the shore. The Kalser' was shocked at the newe. He had been very Irlendly with Francio Ferdinand. When the Archduke and his wife visited Potedam, they were received with warked attention. The Duohess of Hohenberg was recelved as an Archduchess. Th1s mark of reapect touched the Archduke and caused him to appreclate the Kalsex's Irlendship greatly. Just a few days before the fatal shots were fired, the Arohduke entertalned the Falser at his beautiful villa of

5. Bethmann to Srogreny and Ztumerman to Trohlrsonky, July 6, 1913, Grosse Politik, XXXV, . 129 \&f.

6. Ibld., Dp. 204-205, quoting Recouly, p. $29 \mathrm{ff}$. 
Konopisoht in Bohemia.

Berchtold was eware of this friendahip and ut121zed the information to try to gain the Kalser's assistance. He was not diseppointed. The Austrian Ambassador at Vienna reported to Berchtold that Germany had decided ". . that we must judge what is best to be done. - i whaterer wo declde we may always be certain that we will find Cermany at our alde, a falthful ally and frlend of our monarahy". Bethmam telegraphed the Cerman Ambessador at Vienna that, "His Majeaty will falthfully stand by Austria Hungary. as 18 required by the obligations of his elliance and of his encient friendship". Thus cermany handed her Austrian ally "a blenk check".

The Kaleer's declsion was in harmony with his attitude expressed upon the receipt of Trohlrschicy's note June 30 , wherein the latter had cautioned Austria againat hasty action. The Falser wrote on the margin of the telegram, Whow or never. It is solely the affalr of Austria what she plans to do in this case. The serbs must be disposed of and that right goon".

7. Fay, op.olt., II, pp. 32-33, quoting rikitsohBoulles, p.. $115 \mathrm{ff}$.

8. Saopreny to Berchtold telegram, July 6, A.R.B., I. 10.7 . p. 20 .

9. Bethmann to Toohirachky, telegram, July 6, K,D.. 10. $15, \mathrm{pp}$. 78-79.

10. Kautsk Doouments, op.o1t., Mo, 7, p. 61. 
The German govermment had mored repldy. On July 5 and 6 it had: (1) agreed to Austrian military action againat Berbla; (2) recognized that Russla might come into the war; (3) and urged action at once. The Kalser then met representatires of the army and navy. He arked to see the Prussian Hinister of War, but told hIm that milltary preparations need not be 12

made. Thereafter the Kalser salled away for his racation.

Tisza did not know that an appeal had been made to Germany. He counselled moderation and objected to the appeal, pending aditional information from the tragedy. But Berchtold had his way.

Berchtold now turned his attention to TIsza, The Austrian Poreign lintster and count Hoyos: 3greed that it would be necessary to bring pressure to bear upon Tisza. Berchtold then sent a letter to Tissa in which he ald that Germany would consider further negotiating with Serble a confession of weakness on our part. . . He hoped to thus inriuence Tisza to consent to the wax. 13

Tisza held out against wax unt11 July 14. when he Inally conceded that the ultimatum be sent as

II. Austritan Red Book, op.a1t., I, Yo. 7, pp. 20-21. 12. Sentaky pocuments, 0p.c1t.. pp. 14-16. I3. Auntion Rad Book op.c1t., Wo. 10, p. 34 . 
Berchtold suggested. Howerer, he was opposed to any annexations as a result of the war. 24 Inmediately afterward the conference with Berchtold, M1sza went to cell upon Tsohirschis. It was rery hard for wo to come to the declalon". said the mungartan, "to give wy advice for war, but I an now firmly oonvineed of lte peceselty and I shall stand up for the greatness of the monarchy to the utmost of my abil1 ty". Concluding the Interview, Tisza grasped the hand of the Ambassador and declared, "Together we shall now 200k the future calmy and firmly in the face". When the Fafser heard of Tisz"s change of heart he exclaimed, Well a real man 15 at last".

Berohtold, Who more than anyone else wa: 16

responstble for the World War", could now calmly prepare for wax. All the chief offlatals had capltu1ated. Fe was now ready for the ultimatum.

14. Augtrlan Red Book, op.o1t., I, Ho. 19, p. 47. 15. Prohirech to Bethmann, K. D., op.o1t., No. 49, pp. $112-113$.

16. Joy, op.eit., I, p. 28. 
Onapter

The Austritan or timaturn To Berbla 


\section{Chapter $\mathbf{V}$}

The Austrien ol timatum To Serbla

Sha12 Austria-mingary be a door wat to be stepped on by nations, some of whom the had looked upon with contempt in the very recent past? shall the crumbling frolre of the Hapaburgs fall to pleces from Its own weight as the "wonderful One Hoss shay" "P Shall she accept the scom heaped upon her by the serblans wo sald the 01d Rupire was "worm eaten"p Or shall she be torn to pleces by her enemies outside her borders? H1 ther altermative was hard for her to face, If 80 , the kingdom of Franals Joseph, which to the Austrians" way of thinking had a glorlous history, mast crumble into the dust of forgotten nations, and be relegeted to the scrapheap of rusted out oroms.

The world walted; would the pistol shots at Serajero be followed by rlolent exploslona? War ald not 1modiately follow. So Burope began to breathe more eas1ly; the tension was receding. After all, people sald, We are not going to have war". But the1r optimiam was of short duration. It was a peacerul sunday morning July 19 - to be exact. If the Viennese had observed closely as thoy returned from ohurch servioe, they would have noticed a number of private automoblies atopping at Count Bexohtold's residence. It was 10:00 A.11. When the Iast man arrived. Eren Count Flsza, Minister-President of Fungary, came all the way from 
Budapest to this oumer morning meating where the rate of mi1110ns was at stake. Fren the Austrian onlef of Steff returned suddenly from his vecation, ostensibly to be at the bedside of his sick son.

It was the Joint Hinisterial Council in session. They met under the utmost secrecy to make the note to send Serbla, and to $f 1 x$ the date when 1 inlght be most adrantageous for then to send 1t. After mah discuasion it was declded to deliver the note to Sexbla at 5 o'clook P.H. Tmuraday, July 23. Porty-eleht hours were given for the Serblans to answer. If at the end of that time a satisfactory answer had not been recelved, 1t was 21kely war would follow the delivery of the note. The delivery of the note was oo timed in order that the Mustrians might gain a little time on the slavs by ordering their moblilation by early sunday. ' So the note was concluded, and was sent by mesgonger on the nineteenth to the Austrian Minister at Belgrade for delivery July 23. Count Berohtold, Ju2y 20, instructed Baron olesl to tell serbia that, we cannot enter into any negotiations...".

The scene shifts to the capital of serbla. It Is early Thursday. A seoretary from the Austrian ministry

1. Pay, op.o1t.. II, p, 49, quoting Conrad, IV, pp., $78,87,94$.

2. Council of Mnteters for Common Affa1rs, A. R. B., I, 30,26, p. 54.

3. untrien Red Book op.01t.. I, Yo. 28, p. 63 . 
callod at the Berblan Forelon offlce to ask if he might see Pashitah at 4 o'clock that day to bring an "imporm tant comminication". It so happened that this event was almost on the ere of an elootion. Pashitoh was out mending his polltical fences in a distant part of the country when the caller arrited and it wes exceedingly difflcult to reach him. Feedless to sev in that kind of a natlonal emergenay he was located but could not oame in time. So at the appointed timo the Serbian Miniaters wo were in the c1ty net to recelve the Austrian diplamat.

It was unusual for a representative of a foreign power in making an appointwent for a conferenoe to $I$ Ix the time. Iow, however, to add Inoult to infury the Austrian Secretary arrived at the appointed hour saying that Ciesl would not arrive until 6 olclook. Ior was this all the evidenoe to indicate that Austria ohose the time to give her the greatest advantage. For, Dinoe Jamuary, 1914, it had aeemed adviable and had been planned that Poincare, the PresIdent of Irance, vialt st. Petersburg to call upon the Czar. Fear makes trange bedfe210ws. The Republ10 of France and the absolute monarchy of Russia in olose alliance seemed Just as opposite as the poles. So,

4. Berchtold to Geel. July 21, A. R. B., I, I0. 36. 5. Bamat op. eIt.. I, D. 472.

6. Berchtold to ateal telegram, July 23, I, Jo. 62. 
even in the light of rumblings from the sarajevo incident, Poineare felt it mlght cause more discussion if he did not go just at that time than if he remained. So on July 20, 1914 he and his Prime Minister were recelved at the Russian capltal.

Imagine the reception with the Rusglan band play Ing the Marselila1se and the French President drinking a toast to the health of the Czar! It was a joyful occaston. For, sald the Carar in his welcome, it was his hope that France and Russla "wll1 continue to enjoy the benefits of peace which the fuliness of thelr strength ensures by constantly tying more tightly the bands that unlte them". Feedleas to say, Poincare responded in 11ke mannex. "Your Hajesty", aald the Frenchman, "can be assured that France in the future. as alpays in the past will, in alncere and daliy co-operation with her ally, pursue the work of peace and c1712Ization for which both governments and both peoples have never ceased to labor".

$$
\text { 8o, during the three days presence of the }
$$

7. Fay, op.c1t., II, p. 277, quoting Polncare, IV, p. 211 .

8. For The Dar Begen In 1914 , being the Diary of the Fuselan Boreign office from the 3rd to the 20 th (01d ty10) of July, 1914; published by the Red Archlves, Depertment of the Russian sorlet Covermment in their Hiatorloal Journal, Vo1. IV. 1923. Translated from the ori ginel Russian by Hajor W. Gprian Eridge, George Allen and Unwin, Iondon, 1925, Appendix, p.. $113 \mathrm{ff}$. Hereaf tex referred to as gohll21ng's Diary.

9. Schlilingle Diaw, Appendix, P. $214 \mathrm{ff}$. 
Irench, the heads of the two govermments talked over. as did Herbert Hoover and Ramsay HacDonald on the banks of the Rapldan, the common problems of their countries. It seems $21 k e l y$ that the high point of the Frenchmen's V1ait to the Russians was expressed in the utterance of Polncare to the Russian Ambassador concerning possibll1t1es in Austrla when he sald, "Bazonor uast be firm and we mat oupport him". 10

So, after the toasts were oald, the healths drunk, the salutes f1red, and the anthems played, Polncare and Viriani salled away to their native land in complete lenorence of what was about to happen in the city of Belgrade that same evening. For the stage was set in Belgrade. Wo membera of the Serbian cablnet were present at $60^{\prime}$ clock when Giesl appeared at the Berbian Forelen office to deliver the ultimatum. A third member was not present, since he did not underatand French, the diplomatic language, anyway. Baron GLel delivered the note to Serbla July 23, "and added that the time for the ansver had been fixed for saturday at 6 P.X., and that if by that time I had recelved no answer or an unsatisfactory one, I should leave Belerade With the entire legation". With that, Olesl began reading the note but wa intermuted by the serbian who sald he could not teke the responelbillty of hearing the

10. Tray, op.01t.. II, p. 282.

11. Anstrian Rod Book, I, Jo. 67, p. 114. 
note in the absence of his onler. However, the Austrian wald in view of the fact that Serbla was not very large. and that raliroads were avallable, he thought Pashitoh, the Serbian Porelgn Iiniater, could roturn quickly. Any. way. that was not Austria's concern. W1th that he turned on his heel and departed, leaving a copy of the note. W1 th great fear the tro Serblans read the uItimatum demanding that the Berbian government accept the terms vithin forty-elght hours, or suffer the consequences. At the conclusion, Yovanovich turned to the other saying, We11, there 18 nothine to do but die fighting" ! $^{12}$ small wonder the expresgion for, in aubatance, they had just read that Serbla must:

1. Suspend every publication in her country which might cause hatred toward Austriam Hungary.

2. Check the establishment of societies such as "rerodna odbrana", and selze all 1 ts meane of propeganda.

3. Remove from the publis schools everything that might gerve to be antagonistic to Austrla-Rungery.

4. Arrest lajor Voja Tankositah and ulan Ciganovitoh who as a result of the Inquiry seemed to be involved.

5. Remove any officers from hor army whom AustrlaHungary mitht nominate.

6. Accept Austrla-Hungarian representatives to assist in aupressing the attempt against her territorlal Integrity.

7. Allor Austrlan delegates to assist Serbia in ascertaining the guilt of the perties in the conopiracy of sarajevo.

12. H. 7. Armstrong, Three Davs in Belorade July 1924. Jorelon Afralrs Jamary 1927, p..275. 
8. Prevent unlasnul traffio in arms and exploalves across the frontier.

9. Explain the utterancea of high Berbian offlolals who had, alnoe the murder, opoken in host1le terms of the Ihapire.

10. Hotify Austrla-Hungary of the compliance with the demands. 13

When 81r Bdward Orey read the note in Ingland he commented. ". . The note seemed to me the most formidable document I had ever seen addressed by one stato to another that was independent". " Bven the corman foreign winister was moved to say, "As a dip10mat1o document, note left much to be desired".

Pashitch returned home early July 24 . ImmedLately, the Cablnet and the Prince Regent set to work to see what kind of an anower could be sade. Telegraph wires were kopt hot by requests for assistance of one kind or another, such as asking Hitain to request Austria to make the terms of the note $20 s$ arastic, for they "are impossible of acceptance". 16 Very 11 tile news that even encouraged Serbla was recelved from forelgn povers.

And so, into Frlday night and all day Saturday they worked with the note, changing a word here, a word there, "eresures" and "corrections", and "riders". In

13. Austrien Red Books op.c1t. I, pg. 61-62.

14. Grex to Eunger telegram, July 24, B.D., No. 91,

15. Pumbold to Oxex telegram, July 25, B.D., No. 122, 7. 91 .

16. Greckanthorpe to Grev, telegram, July 24, B.D., No. 92, D. 74 . 
nezrous haste they gave the anaver to the typiat, and to add to the difficulties, as timo rapidiy ticked away, the only typerriter refuned to work and the coples had to be made by hand. Just ten minutes before the time limt had expired, namely at 5:50 P.I., Pashltah grasped his hat and the document, and ralked to the Austrian lejation winere promptly at 6:00 P.I. Baron alesl recelved him. 17 we have sccepted part of your demands". sald the serblan. "For the rest, we rely on the loyal and ohivalny of the Austrian ceneral. Te have always been quite attiafled with you." 18

The Serblan government in its reply to the Austrian ultimatum agreed to:

I. Publish in the "Journal offlctal", July 26 , a condermation of all propaganda directed at Austria-Hungery and warn all persons that it v111 proceed to punish those who may spread ant1-Auvtrian propaganda.

2. Provide for the punishment of the preas who may incite hatred ageingt the Austro-Fingarian ronarchy.

3. Missolve the Forodna Odbrana and similar socleties.

4. Remove from the curriculum of the schools anything the Dual Nonarchy deemed propaganda.

5. Remove all civil and military officlale that have been proved "guilty of acts alrected agalnst the territorial integrity of the Austro-fingarian Honarahy".

6. Accept the collaboretion of Austrian offlolals in

17. H. I. Armstrong, Three Dave in Belarade, July 1924, pp. 273-274, Foreign Afrairs, Ho. $\nabla$, Jamary 1927.

18. Sohmitt, op.oit., I, p. 533, quoting Giesl, pp. 268-269. 
so far as the ruzings of international lat would sanction.

7. Undertake an investigation of those accused of being Implicated in the plot of June 28, 2914 . "As regerds the participation in this inquiry of Austro-mungarian agents or authorities appointed for this purpose by the Imperial and Royal Government, the Royal Government cannot accept such an arrengement, as it would conotitute a riolation of the constitution and of the law of oriminal prooedure; nevertheless, in concrete cases cormunioations as to the regults of the investigation in question might be given to the Austro-hungarian agents."

8. Attempt to arrest commandant Voja Tankoritch and Milan Ciganovitoh.

9. Check 111101t "traffic in arms and explosives across the frontler".

10. Iurnish explanation of derogatory remarks against Austrla made by Serblan officlals after the assassination.

11. Motify the Austro-Hungerian Government of the execution of the meagures proplded in the note as rapidiy as posslble. Serbia agreed to aubmit any phase of the question to elther the International Tribunal at The Hague or to the Great Powers. 29

But alesl could not accept the terms, for "any acceptance which containa conditions or reservations you are to consider in the light of a refusal". Maturally it required only a hasty perusal by Giesl to see there was not an unqualified aoceptance. Count Berchtold had overlooked no detail. Baron Glesl had been

19. Scott, piplomatic Documents, op.c1t., I, (Austrian Red Book, I, 1.o. 34), pp. 88-98.

20. Austrian Red Books II, Ho. I, p. I. 
glven explicit directions.

"I asaume". the Count pired the Baron, "that according to the ingtructions you have recelved you have completed your preparetions so you cen leave Belgrade immediately . . Should the termo of forty-elght hours lave expired without effect. The result is to be aent in a few Fords from semin in olarle and lrodiately to the military cablnet of His Imperial and Royal Apostolle lajesty at Ischi; also in glarta from semin and In clpher from Belgrade to the Inisiry of Foreion Affairs and count Tisza in Budapest. - It 112 be best for you to eventually leave Belgrade by the 6:30 train which arrives at semIn at $6: 40$. Then you arrive in semin you $\forall 112$ uge the offiolal railway telephone at the station and get a telephone connection with the Budapest rallway directors who must comect you with count TIsza whom you are to Inform of departure from Belgrade. . . We might recelve the nows of your departure as early as 7 o clock on Baturday. "

So the remarkable exhibition of speed which was in evidence since Berchtold decided to move against Serbia was shown again, for the Beron had even propared a note to the Serb1an Forelan Minlater before he recelved the serbian reply in which he stated, "I have the honor to inform you that I em leaving Belgrade this evening wth the staff of the Imperial and Royal Iegation".

Within fifteen minutes the minister and his retinue were at the station; the train left at 6:30 P.M. As soon as he crossed the river, which was the frontier, intrusemin he was calied on the telephone by risza at

21. Berchtold to alesl, telegram, July 24, A.R.B., II, No. I, $\mathrm{p}$. I.

22. H, F. Arms trone, Feterul Documents of The vorla War, Current History, XXV, October, 1927. $\mathrm{pp}$. 92-93. Scott, James Erown, Blplomatle Documente Pertaining To The outbreak of the miropeen Ler (8erbian Bive Box) 10. $40, \frac{1}{1476}$. Hereafier referred to as Scott, Diplomatic Documents. 
Budapest. Tlaza said, "Must it reoliy be?" An affirmative answer, of course, was the reply. Count risze relayed the information to Berchtold at Vienna, commenting especially upon the fact that at mid-afternoon that day the Serbians had ordered moblization and had moved their government away from Belgrade. 23 aleal, also, sent a message in olpher to Berchtold.

With that, the Baron went aboard again and the train rolled on through the night, and stopped early the next morning at Budapegt where Tisza and Giesl talked more specifically about the events of the past fer hours. Iate that same afternoon Vienna was reached, and Gies 's Journey home was ended. Short2y after he wes engaged in conversation with Count Berchtold.

In the meantime the serbian reply had been flashed round the world. That the reply was conclliatory seamed to be the consensus of the opinion of most of the statesmen. Even William II was moved to say, "A brilliant performance for a time limit of forty eicht hours.

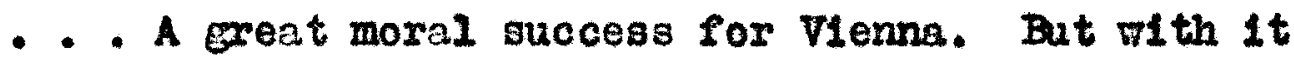
every reason for war drops away and olesl ought to have remained quietly at Belgrade. On the strength of this I should never have ordered moblilizetion".

Some of the demands mere met completely; some, part1ally; only one refused, and a request was made to

23. Telephone message from Glesl, Ha Budapest, July 25, A. R. B., II, No. 26, p. 23.

24. Kautsky Documents, No. 271. 
refer that requirement to The Hegue. That point was the demand that Serbia allow Austrian officials to help search out Princip's accomplices in the assassination.

So in the face of nine-tenths of the demands conceded, Austria decided for war; for had not Berchtold sald that if serbla swallowed the terms it would be "rery disagreeable to him.

The fact is Austrla had decided for war. The last word of the diplomat had been spoken. He ranlshed from the scene. The soldier took his place.

One day long after these events, there appeared at the former Austro-Fungerion Legation in Belgrade a man visibly aged. He wanted certain legal papers to quallfy for a government ension. This man was Baron olesl. How different wes Burope! How different was the Baron! How changed was his demeanor from that hot sumer day in 1914 When the otrapped $u$ his brlef case and rolled away to the station".

25. Kautsigy Documents, No. 29.

26. 苂. F. Armo trong, Imree Dave In Belerside, Forelen Affairs, Volume $\nabla, \mathrm{p} .275$. 
Chapter VI

The vitimatum Foriss 
Chapter $\mathbf{n}$

The UItImatum Works

"It is very bed. It vill mean war, " ${ }^{2}$ deolared I. Pashitch, Prime Minister of Serbla, when he heard the nevs of the fateful events at Serajevo. Pashltch was right; Berchtold had indloated at the conclusion of the "Lemo1rs" (a copy of which wes sent to Wilhelm II July 2,) that $1 t$ vas necessary for Austria to Erasp the net woven by 1 ts enemies and tear them once for al1"." Francis Joseph vrlting to the Kaleer declared that a "conciliation between serbla and us is out of the question" 3 - . Count Tisza, writing to his moror and King from Budapest JuIy 1, Indicated the further att1tude of Vlenne when he wrote that he had just learnod Count Berchtold's intention of making "the horrible deed of Serajevo the occasion for reckoning with Serbla".

When the fulesian minister at Belerade heard the tragtc news from Serajevo, he declared: Heperons que ce ne sera pas un Serbe". (Iet us hope it was not a Serblan.) The Two shots at Serajevo caused Russia to be quite disturbed for she had been for oenturies concerned about events in Southeastern Iurope. Of course the Poin-

1. H. 3. Armstrong, Three Daye In Belerade in Forelen Affairs, $v$, Jamuary $1927, \mathrm{pD} .267-275$.

2. Austrian Red Book op.oft.. I. p. 13.

3. Ibid. Io. I, p. 3 .

4. Austrian Red Book, op.o1t., I, Ho. 2, p. 14.

5. Sautsky Documents op.c1t.. No. 10, p. 64 . 
care vialt to the Rusian capital had excited attention among, at least, the higher classes of Russian soclety. At the banquet, which the Grand Duke HIcholas geve to Polncare July 22, two princesseg, wites of two Grand Dukes, vere talking vigorously:

"Do you know that we are passing through historic days, blessed days! Tomorrow, at the review, the bande will play nothing but the Yarohe Iorreine and Sambre et Houge. Today. I had a telegram from father in the proper style; he tells me ve ahall have war before the month is out. What a hero, my father! He is worthy of the IIIad. Here, look at this 21 ttle box - it never leavea me; 1t has Iorralne soli in 1t, yes, Iorraine s011. which I collected bey and the frontler when I was in Irance two yearg ago with my husband. And now look at that table of honor! It is decorated entirely of th thistles; I would not have any other Plorers put on it. Hov then! They are this tles from Iorraine! I ploked a few otalics on the territory annexed (by Cermany); I brought them here and had the seeds sown in my garden. Well tza, talk to the Ambassador some more; tell him all this day means to us, while I go to recelve the Tsar."

The Ambassador was seated next to the Grand Duchess Anastarla. She mede many remarks, mixed with prophecies:

War is golng to break out. Hothine will be left of Austria. You vill get Alsace-Iorraine beck. our armies W111 meet in Beriln. Germany 7111 be aminilated." Then suddenly, "I mast control myself, the Trar is lookine at me," 6

As Paleologue introduced his colleagues to the Prosident of France, the latter took the opportunity to say a rord here and there, to each of them. When the Austro-fhungarian approached, Poincare offered his condolence orer the Serajevo affalr. A scene in diplomatic

6. Pay. op.c1t.. II, p. 233, quoting Paleologue, I. p. 14 fr. 
fencing tooir place. "Have you eny now from serblap" ald the Frenchman. To which the Austrian frigldy replied: "The investigetion is adrancine." One rord brought on another: finaliy, the Austrien said, We cannot tolerete. Mr. President, that a forelgn governmont shall allow murderous attacks to be prepared on 1 ts soil acalnst our sorereienty." Polncare made a thrugt under the Austrian's guard, however, when he sald, with 2. I1ttle good w111, this servian affair is easy to settle. But it is easy for it to become envenomed. Serbla has very warm friends in the Russian people. And fussia has an ally. Franoe. What complications are to be feared here?"

When count saspary reported his conversation to Count Berchtold, he ald not fall to say that Polncare'g influence would not be very favoreble toward exercialng calmess.

It was easliy ween that Russle would very probably make Serbla's flght her own. Raclel and rellglous ties, not to apeak of events in the Balkan peningula, held the attention of Rugsta. She had been interested in Conotantinople for centuries, for it guarded the outlet to the Black Bea. It followed, therefore, thet any quarrel between Austria and serbla could very easily involve Russia. If it involved

7. Fay, op.eit., II, p. 231, quoting Paleologue, I. p. $0 \mathrm{ff}$.

8. Austrian Red Book, op.c1t., I, Jo. 45, pp. 98-99. 
Busola, her ally Irance wouid 1ikely become interested and, before the Fowers realized 1t, all Burope might be arlame.

Even Bir Edward Grey was interested in cheoling the rax. He expressed the hope, July 20, that effort anight be made "to prevent any breach of the peace". Austria and Rusgie should discuse matters together if they should become difficult. ${ }^{9}$ crey advised the new British minister to serbia that it was not Britain's "business to take violent sideo in this matter". Grey drew ${ }^{\prime}$ sharp line of distinction... between an Austro-serbian and an Austro-Russian quarrel. In the f1rst, he de not wish to mix as it did not concerm him. But an Austro-Russian strife meant, in the ciroumstances a vorld wer". 11

Ferchtold did not healtate to sey that he thought the tragedy of Serajevo was a matter between Serbla and Austria alone. In other words the Count mas interested in localizing the rar. Von Schoen agreed thoroughly with the Augtrian Forelgn Hinister's point of view, for he sald: "It is a tter of common Interest for all monarohleal govermments that the Belgrade nest of anarchists be once and for all rooted out and it (Germany) w11I make use of 1 ts influence to get

9. Brit1oh Documents, op.cit., Ho. 67, Dp. 53-54. 10. IbId., Ho, 79, p. 64.

11. Ilennowskr to Ianom, K. D., telegram, July 25, To. $180,2.200$. 
a.1 the Powerg to take the view that the settiements between Austrie and Serbia is a matter between those two nations alone". 12

A Britlsh alplomat expressed a strong opinion on "localizetion" when he sald, "I can quite understand Russia not boing able to permit Austria to orush Serb1a. I think the talk about locallaing the war merely means that all the Powerg are to hold the ring while Austria quietiy strangles Serbia. Thia to gy mind, is quite preposterous, not to say inlquitous".

Sazonov had expressed Russla's plewa very succintly, for he had sald "In the most determined manner that it would be quite impossible for fussia to adnt that the Austro-Serblan quarrel could be settled by the two partles concerned.".

The Russian Foreign Minister is quoted as say ine. Hatred is no part of my character: therefore, I feeI no hatred toward Austria, nothing but contempt". Andway it was his opinion, he sald, that Austria vas on the lookout to "avaler" (devour) Serbla. "In that event, however" declared the minister, "Russia will go to war with Austria." When it was guggested thet Austria Intended no annexation of Serbian territory. Sazonov sugeested a prophetlo polloy for Austria. "For

12. Kautsky Documents, op.c1t., Supploment IV., Xo. 2. pp. 617-618.

13. British Doouments, op.c1t., No. 239.

14. Pourtales to the Zoreion offlce, K.D., July 25. 
Serbla was to be eaten up, then it was Bulgarla's turn, and then we shall have them on the Black sea". 15 Fren the Itallan Ambassador as early as July 16, urged furgle. to call to the attention of Viemna that "Russia would not endure any infringement by Austria of the integrity and Independence of serbia". 16

Poincare, while at St. Peteraburg, declared to the Aurtrian Ambassador that the Serblans have Iriends and it was inposstble for a situation to rlse which might be inimioal to peace. Ir Iridently Poincare was attempting to bluff Austria and at the same time encourage Rusala.

Bethmann-Holiweg Indicated Germany 's atti tude on JuIy 23, when he cald thet the att1 tude of cermany then would be that the difficulty is one which "affeots Austria and serbla only".

When S1r Hdward Grey heard the contents of the uItimatum, July 24, he expressed the bellef that it might lead to trouble between Austria and Russia. If Austria moved her troopg agalnat Serbla, Russia would moblilze. This would cause the peace of lurope to be endangered. Grey coneldered, lt required two to koep

15. Pourtaleg to Bethmann. X.D., JuLy 25, Ho. 20, pp. 213-214. Cf. Brapary to Berchtold July 26, A.R.B.. II, I08. 27, 19 and sohliling's Diary, op.eft.. pp. $32 \mathrm{ff}$.

26. Eonquingtg praxe p. 25.

17. Iustrien hed Book op, o1t., I, No. 45, p. 98.

18. Bethmang to the Inteter in the Imoerial sulte, K. D.. . . 125, D. 165 . 
peace" nov, even as it ordinar1ly took "two to make a quarre 1". 29

Crey proposed that the four Powers, Germany, France, Italy, and Finglend, work together at Vienna and st. Petersburg in favor of peace in the event that Austria and Fussia threatened one another. 20 The reutonlo nation approved; France delayed occeptance for she favored mediation between Austria and Berbia; Bussia also found objeotions to 1 t.

The storm clouds of war were getting very dark by July 26. Sazonor wes now ready to ellow Fnglend, Irance, Cermany, and Italy to handle the thorny problem of diplomatic necotiationo in the Balkan area.

On the strength of Bazonor's request, although Erey was out in the country, Micholion sent the message asking if Parls, Beriln, and Rome would be willing for the ambassedor of each to meet with orey at Iondon in conference at once in order that an attempt might be made to arold hostilities. Italy accepted the same day. France the day following, fuesla was at the moment favoring "direot convergations" with Austria, but

19. Grex to Bunsen, B. D., No. 86, p. 70.

20. Crey to Ambola, telegram, Juiy 24; Scott, Diplomatic Documents, op.o1t.. (British Hive Book, I, I0. 11). p. 885 .

21. Bughanain to Grev, telegram, July 25, B. D., Mo. 125, p. 93.

22. Floholigon to Grey, telegram, July 26, B. D., Ho. 139, D. 100 .

23. Rode to Grey telecram, July 26, B. D., Ho. 154, p. 107 . 
If hopeful reaults were not real1zed, she would accept the Britiah proposal. Three of the Powers thus accepted the suggestion; Beriln, howerer, declared ahe was unwliling to call Auvtria Into a furopean court of justice on the serblan case. The Cermans at that hour vere st111 clinging to "locellzation". 25 Fallure. therefore, was the end of the latest proposal for stopping the wer.

Cermany now becked up the proposel of sazonov for "direct conversations" between Austria and Russla. The latter together with the Austrian ambassador at st. Petersburg discussed the ultimatum. Finally Sazonor, turned to hls compantion, and remarked, Take beck your ultimatum, modify 1 to form and I w1L guarantee the result". At this juneture just one barrier to peace wa in the way. Berohtold wanted war. To prevent medlation Berchtold succeeded in getting Francis Joseph to agree to wax. 27 The cerman Ambassador at VIenna sent in h1s report to Beriln as follows: "They have declded here", he said, "to send out the deolaration of war tomorrow at the latest chlefly to frustrate any attempt at intervention".

24. Bertle to Orey, telegram, July 27, B.D., Mo. I83, B.D. Fo. 194 .

25. Bethmenn-Eollireg to Habnorrky, telegram, July 27. Z. D. op.01t. Io. 248, p. 237.

26. Soott, Diplomatle boouments, I, (Brench Yelzow Book, 10. 64), p. 606 .

27. Ibld, 2. 400 .

28. Trohirgahisy to The Foreten offloe telegram, Io. 257. Cerman Ver Documents, International Conc11lation, p. 232. 
Berchto2d was now in position to meet all modiation proposals that came his way. When the Russian Ambassador approached Berchtold w1 th the idea of "alrect conversations" the latter was able to say that he could not consider the proposal for mar on serble had been declered today". To Germeny and Ingland he sald, that the latter's proposel for a conference was "too late". In view of the otate of war already existing", he sald, it was been outstripped by events". "Prest1ge of the Dual Honarchy was now engaged, and nothing could now prevent confliot".

Berchtold was so anxloue to get the Imperor to approve the stand for wer that he lald before the Buperor the draft of a telegram to serbla. In the report he sald that he had spoken to the "Commander of the Balkan forces" and "to the ohlef of the General staff". as to the advibab111ty of declering war the following day. Ho objection was offered. It is htchly interesting to note here, howerer, that conrad had recently told Berchtold he could not possibly have the army ready for an attack before Augugt 12 . This answer was in response to a question of Berchtold, July 26, who had asked Conrad when he preferred the outbreak

29. Augtrian Red Book op.c1t., II, Io, 95, p. 158. 30. IBta.. Fo. 81, p. 145.

31. Eungen to Grey, telegram, July 28, B.D., Jo. 227. p. 151.

32. Austrien Red Book op.c1t., II, Jo. 78, pp. 238-139. 
of war. No whlch Berohtold replled, "But the diplomet10 of tuetion 7111 not last as lons as thet".

Berchtold was careful in this report to Irancis Joseph, who was at Ischl for his health, to say:

"According to the report of the 4th Corpe-Command, Serblan troops on Danube steamers near Temes-Kubin fired at our troope who also gave fire, so that the encounter lasted same time. Hostilities have therefore begun, and it is adviable that we should give our army that freedom of motion to Which $1 t$ has $r 1$ ght when the otrite of var has been proclaimed." 34

The peror and Fing urote on the communication recelved from his Jorelon Hniater the following: "I approve of the enclosed draft of a telegram to the Serblan Joreign Off1ce, containing the declaration of war to sexbla and authorize you to do as your propose."

The telegram which the aged monarch slgned wes the declaretion of war. It contalned the following crypt10 atatementa:

The Royal goverment of Serbla not having enewered in a satiafaotory manner to the note which had been presented to 1t on the 23rd July 1914, the tmperial and Royal Govornment finds 1 trelf in the necessity, to Insure for itself its rights and intereats, and for this purpose to heve recourse to the force of arms, all the more because the Serblen troops have already attacked a detachment of the Imperial and Royal ermy near Temes nubin. Austrla-hungary, therefore, from this moment considers 1tself on a footing of war wh serbla.

The Mnister of Jorelon Affalrs of Aus tr1a-Bungary

stened. Francls Joseph. Gount Berohtola"

33. Fay, op.01t.. II, p. 417, quoting Conrad, IV,p. 132

34. Augtrian Red Eook op.c1t., II, 30. 78, p. 138 .

35. Ib1d.. 2. 139 .

36. Ibla.: Berchtold to serblan Jorelen Minister telogran, JuIy 28, A.R.B., II, Io. 78, DP. $138-141$. 
Irom the time, however, that the Huperor olgned the declaration to the time the telegram to Serbla was oent, the message wad changed materially. The document recelved by the Serbian Foreign Minister ald not oontain the phrase. "all the more because the serblan troops have already attacked a detachment of the Imperial and noyal aruy near Temeo-nubin". 37

Wo are justlfied in believing that Berchtold was afrale Francis Joseph would not approve the declaration of thout some rery specific attack by the serbs. So having prooured the hichly prized slenature he had no further uge for the phrase and thus omitted It from the araft of the unooded telegram sent to II Bh at 21:20 A. 11. July 28, 1914. On the dey following the sending of the telegram he sent a report to Francla Joseph. In 1 t he sa1d that he had removed from the declaration of war directed against Berbia, the sentence concerning the attaok of seribian troops near Temes-zubin". He asked for the "graolous sanction" of the Buperor and King to the elimination of the 38 phrase. Dut the work was done for either with ox Whout the phrase it was war.

37. Scott, Diplomatie Dopumenta, op.cit. (serbian Blue book E, 10. 45), p. 1479. 38. Berchtold to Branols Joseph Juiy 29, A.R.B.. III, To, 26, p. 27. CF.A.R.B., II, Zо०, 78 and 97. 


\section{Cupter vit}

Tho Pussian Nob121zetion 
Chapter VII

The Russian Mob1lization

In St. Petersburg the official vialt of Poincare ves over. The Brance steaned aney from the Russian capital for home. The French President was vell satisfied with his reception in Rugsia. It vas unisualiy late Then the Russian diplomats retired for the night.

The Russians vere avakened the next morning to the nevs of the Austrian ultimatum to Serb1a. Then Sazonov digested the substance of the Augtrian note, he hastened to be ready to keep the diplomatic channelo open between the Russian cajttal and the other capitals of Burope. The Foreign uinister must have done much speculating about the posalbilities of rar before the ultimatur, for he unheeitatingly sald to Baron shiling as he met him upon his return to the Capital, "It is the European War". The Czar did not make such an outspoken remark when he heard the news for he merely said, "This is disturbing". and ordered that he be kept advised of additional ners.

Almost imedlately the diplomatic jockeying began, for Count Szapary of Austria cane to see Sazonot in order that he might defend the very momentous announceof his govermment. Hed there been a polltical barometer

1. Schtling's Dlarg op.cit., p. $28 \mathrm{ff}$. 
functioning at that time in the Buple of the Bear. undoubtedly the berometric pressure would have dropped to a lor almost comparable to that of the period just preceding the outbreak of the Russo-Japanese war in 1904-1905. The tro tactful masters of the art of diplomacy matched steel against steel in their discussion. Szapary started to read the ultimetum and explain its contents with frequent interruptions from the Russian. "The fact is, you want war and have burned your bridges". sald Sazonor. The Austrian said in response to this rejoinder, Whe are the most peace-loving Power in the Forld, but what we want is security for our territory from forelon revolutionary intrigues and the protection of our dynasty from bombs". "One vees how pactfic you are, now that you are settine furope on fire", sald Sazonor, and he continued furthor, "I know what it is. You want to make war on Serbla! I see what is happening, the German newspapers are eggine you on. You are setting fire to Turope. It is a Great responsibility you are assuming; you 7121 see the impreasion that this w111 make here and in London and Paris and perheps elsewhere. It 7111 be considered as an ungutified agcression".

Bazonov, having, as he believed, correctly read the political barometer, gazed upon the horizon to the westward. As has been indicated before, it appeared to

2. Szapary to Berchtold, telegram, July 24, A.R.B.. op.c1t.. II, No, 16, p. 13. Cr. A.R.B., II, No. 17, 18 , and $\mathrm{K}$. D., Bo, 148 . 
nim that Austria intended attackine Serbia, and thet right soon. Of course, he knew the diplomatic game well enough to belleve that, very 11kely, Szapary might have made wrone impressions.

In splte of these impressions, however, there was enough to be seen to indicate that Russia should make some moves in the direction of protection. so, he began to call his subordinates around him and to give directions of the moves to be made on the international chess board of Burope. If the Austrians vere bluffing, he decided that a partial moblization of the Russian army might stop any attack upon serbia. Sazonor wasted no time in 1ssuing ordera for the Counc1l of Ministers for 3 o'olook the same day. All high offictals who were on vacations vere ordered back to their posts. Withdrawal of state deposits in Germany was recomended. A conference was held with the Chief of the General Staff on the advisability of partially mobilizing the army.

Did Sazonov realize just what mobllization, or even partlal moblization, meant? Once an army 18 organlzed for war, even though behind its frontlers, there $1 \mathrm{~s}$ a strone probability that some private or privates may brine on the overt act which may mean war. Too, if it so happens that a potential enery is mobilized behind its frontier, perhaps Fithin shouting distance of the first group. var is almost certain to follow.

3. Sohililing's Diary, op.c1t., pp. 28-29. 
of course Russia justified her movement on the basis that she felt that Austria intended to blot Serbla off the face of Burope; divide the territory among her frlends; keep some herself, naturally; and use the territory she gave avay to gain nev friends. Moreover, the Serbs were Russia's kinsmen. They looked to her for advice and for assiotance in case a larger nation should attack them. Too, Russia had been interested in the Balkan region. She had indicated her interest in the Crimean Tar of 1854-1856 and in the war in 1877-1878. She felt that she had been deprived of her $j$ lat dues in the way of territory, largely by the Teutonic Powers. Although Bismarck of Prussia had declared, "that the whole Bolkan peninsula was not worth the bones of a Pomeranian Grenadier". yet he later, perhaps reluctantly, chanced his mind. During several centuries Russia had desired Constantinople for the stralts hard by are the natural outlet of the Black Sea region. Here was the outzet to the granary of Europe. Anything, therefore, disturbing to the balance of power in the peninsula would naturally aisturb Russla. The Russian Foreicen Minister hastened to the

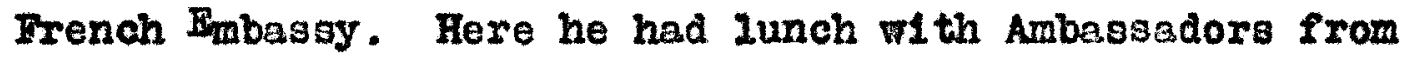
Par15, Iondon, and Buoharest. He did not hesitate to say to the diplomats that "the steps taken by Serbia meant mar". He asked that there be agreement between Russia, France, and Ingland. The French Ambassador did not heg1tate to say. "Brance would not only give Russla strong diplonat1c support but would, if necessary, fulfill all 
the obligations imposed on her by the alliance". The Engl1shman was not so reassuring for he wao not at all certain that Ingland would come in since his country was not interested in Serbia. In his report to Iondon, Huchanan declered that 1 t almost looked as if Brance and Russia were determined to make a strong stand even If wo declined to join them".

Bazonov next met with the Council of Ministers at the appointed time. The pointo decided were: (1) to request Austria to extend the time limit in order that the Powrers might satisfy themselves of the inquiry; (2) to esk Serbla not to rloht, but to rest her case w1th the Great Powers; (3) to moblilze four military districts, depending, of course, upon developments; (4) to take such other military messures as seened expedient.

Sazonor had decided that the Powero mist alt in judgment upon the Austro-serbien altuation. Fe was not even interested in hearting the German Ambassador sugGest "locellzation" for the confliot. Sazonov. replied that Austria ranted to take Serbla, and if she does more in that direction, "Russia $\nabla 111$ go to $\nabla a r$ जith Austria". Pourtales was unviling to bring the difficulty of the Austro-Serbian trouble before a court of Furope. It seemed to him "to be absolutely impractl-

4. Buchanan to Grex, telegran, July 24, B.D., op. c1t.. No. 10I, D. 80.

5. Schilizne's Diary p. 30 . 
cable". he seld.

$$
\text { At a dinner in st. Petersburg, the Czar's }
$$

Equerry declared to Von Chellus of Cermany, "the altuation 18 very serious". Highly significant was an expression of a Russian general who declared, "The guns along the Dambe have probably already commenced their fire, for one only sends a note like that one after the camnon have been loaded".

Sazonor was a very busy man. Another council meeting vas held the twenty-fifth. The Czar was present. It was decided that partial mob121zation should follor. They hoped by this means to bluff Austrie. Into a settlement with serbia and Russia. It would, 2180, Give Fupia time to prepare for war. Decision was made to call the troops to their stending auarters, for their complete equipment was there. The order which went out at 4:20 P.H. July 25, cauged the movement of a milifion or more men throughout Russia. In addition, 3,000 cadets were made officers immediately. At the st. Petersbure Milltary Academy, the Czar addressed the cadets say ing. Belleve in cod as well as the greatness and elory of our country. Seek to serve Fim and we with all your strength". A vtate of war in towns containing fortresses and along the German and Austrien frontiers was proclaimed at

6. Pourtales to Bethmann, K.D., op.01t., Mo. 204, p. 213.

7. Ghelius to the Kaiser, July 26, K.D., op.c1t., No. 291, p. 269 . 
1100 A.H. Ju2y 26.

It seemed evident, sald an arry man, that "war 9

was already a settled natter". "Russia cannot allow Austria to crush Serbia", sald Sazonov, "and become the predominant power in the Balkans and secure of support of France; she will face all the risks of war".

Sazonor apparently believed that Austria and her ally did not think that Russia would back up Serbia. If Russia would call into play portion of her potential arro, the Central Porrera might hesitate before they plunged the Forld into the abyas of war.

In addition to this belief, the Rusian high command thought war imninent and that they should make the most of preparation before the other nations started their preparation. So the minister of war was directed, "to proceed imediately to gather stores of war material". even before the order for partial mobilization.

As time passed and Austria did not imnediately declare war. Sazonor became more at ease. For three daya before the Austrian declaretion of war upon Serbla, the Minister became optimistic. In the meantime Sazonot suegested to Berchtold that Russla and Austria talk over their difflculties. Sunday and Monday passed and Berch-

8. Pay, op.c1t.. II, pp. $307 \mathrm{ff.,} \mathrm{quoting} \mathrm{telegram}$ 1566, General Staff, Hoeniger, p. 80.

9. Ib1d.. I. E. 319.

10. Duchanan to Grey, July 25, B.D., op.c1t., No. 125.

11. Berme日, H. B.. The Genesis of the verid Har Alfred A. Knopf, Met York, 2926, p. 336 . 
told did not reply to the proposel for modiation. However, while Sezonor was waiting he recelved the news of the Austrian declaretion of tar upon serbia. He sent a message to the Russian Ambessador in Berlin in which he announced thet because of the declaration of rar, Fussia would mobilize four military districts the following day. 12

Sezonor went to the czar to get him to accept mobilization. No record was kept of his visit. But short2y aftermard the Czar sent the Kalser a message. -. An Ignoble wrar has been declared to (s1e) a weak country. I foresee that very soon I shall be overwhelmed by the pressure brought upon me and be forced by extreme measures which will lead to war...."."

The Onief of the Aussian General staff went to the czar the next morning. He carried with him the order for partial mobilization; also on order for general mobllization. He was able to get the Czar's signature for partial mobilizetion without serious difficulty. 14 (Very 11kely the Car slgned the order for general nobilization, too.) It was necessary to get the s1gnatures of the Uinisters of Far, Marine, and Interior. These were procured without difficulty. The fact that Sazonor had

12. Dickinson, G. Iowes, InternationaI Anarohy. The Century Company, Nev York, 1926, p. 429, quoting Rombers, $\mathrm{p} .35$.

13. The Caar to the Zatiser Schilling's Dtary, p. 46,

14. Fay, op.c1t., II, p. 452, quoting telegram, No. 1785. Ianushiserich to Th111nsk1, July 29, 1914.

15. Fay, op.c1t., II, p. 454, quoting Dobrorolaki, p. 205 . 
amounced partial mobilization before soelng the Czar Indicated how sure he was that they could get the slgnam ture of that dienitary. For Ficholas II was 11kely to agree with the lagt man who talked with him.

In the meantime the offlce of the Central Telegraph Office in st. Petersbure was busy. The mob111zation order was to be sent to a.l parts of the great Hmpire, About a dozen instruments vere made ready to send the dispatch. It was 9:30 P.I.; the crar had changed his mind. He ordered partial moblilzation instead of general mob1lization.

The Kalser had sent the Carar a telegram. In 1t he sald that Russla by remaining neutral in the AustroSerblan war could prevent "1nvolving murope in the most horrible war she ever itnessed. I think a direct understanding betwcen Your coverment and Vienna poss1ble and desirable". sald WiIhelm, "and as I elresdy telegraphed you, Iy dovernment is continuing its exertions to promote 14 ".

Sazonor and the military leaderg vere determined to secure an order for ceneral mobilization. They knew hussla was a very vast country. Her population was largely rural and, of necessity, wldely scattered. She was the most backward, perhaps, of any of the Ihuropean

16. Fay, 02.cit., II, pp. 455-456, quoting Dobrorolsk1, p. 107.

17. The Kalser to the Gaes July 20, Schllingtes Diary. D. 55 . 
countries. Lany of her roada were mere paths and especially in the winter time they mere practically impassable. Her rallroads were few, and consequently there wore vast distances between rallroads. The morement of troops and war materlals would, therefore, of necessity, be rery mach slorrer than in highly industrialized countries such 28 , Germany and Austria. Vast diotances would need to be covered to transport troope from one part of the Empire to the other. Russia must, therefore, begin milltary movements before her enemies. Sazonov told the Czar that France would be displeased unleas Pussla lirod up to her obligatlons as an ally; that Germeny might convince France that she should remain neutrni and if she did, Pussia vould fall a victim to the German army.

The Russian Chlef of staff awaited Bazonor's visit to the Cacr. He ranted a message es soon as the Czar had signed the order for moblization. "After this". the Ghief of staff sa1d, "I vill retirc from sight, smash my telephone and generally adopt measures which w111 prevent anyone from finding we for the purpose of giving contrary orders which would agein stop our general mob111zation". 19

Sazonov's arguments were convindine to the Czax, but not before a strugele. "Think of the reaponsibility which you are asking me to take!, sald the Ozer. "Think

18. Fay, op.cit., II, p. 469, quotine Dobrorolak1, p. 108.

19. Soht11ing'g Dans op.cit.. p. 64. 
of the thousands of men who wIII be sent to the1r death". Diplaney had concluded its Fork. The czar thought of the safety of his foplre. It would not do at all to allow Cermany to surpriae Russia.

Sazonot telephoned the Onlef of staff. Wow 21

you can smagh your telephone". For at 4 P.II. the Czar direoted that the troops be called to the colors. By 5 P.I. the three necessary 1 gnatures had been obtained; and at 6 P.X, a momentous message went out to the Buplre as f0120w日: "His Hajesty orders: the arry and navy to be placed on a war footing and to this end reserviots and horses to be called up, according to the moblilzation plan of the year 1910. July thirty-f1rgt is to be counted the flrst day of moblilzation.

mob111zation means war". Thls was accepted a. a trulam by military men of murope.

Russia, of course, justifled her general mobli1zation by Austria's declaration of war agalnst Berb1a, because the latter involved possible re-organlzation of the Balkan peninsula. Austrla had not agreed to any of the requests that fursia proposed, namely, the lengthening of the time of the uItimatum, the dealreblilty of using the Sexblan anewer to the note as a besls for additional discussion, or the offer of "direot

20. Sontiling"s Diany, p. 60 . 21. SThIIngte Diary op.61t, p. 66 . 22. sabmitt, op. alt., II, p. 245, quoting Irantz, D. 265. 
conversations", Eron the authorization of partial moblization brought no concession from Austria.

Austrla all along seemed to feel that Russia would not flght, but Austria was wrong, and because of her bad guess the world was brought into the titanic struggle. 


\section{Chapter VIII}

France Stands Hy Her AlIy, Rurss $2 a$ 


\section{Chapter VII \\ Irance Stands Fer A1Iy, Musia}

Certainly France felt keenly the oting of Bismarak's work wich made possible cerwany's supremecy in the Iffe and death otruggle of 1870-1871. Paris had kept wreaths at the foot of the statue of the lost of ty of strassbourg for years. France could not forget the lost provinces of Alsace and Iorralne. Sentimentally, they were of ereat value to her; polltically, they were quite significant, since Germany was thus permitted to increase her territory on the veat side of the Rhine river; economfcally, because the iron mines of Iorraine and the coal mines of the Sar valley were of tremendous importance. undoubtedis, Jealousy existed in Irance because of cermany's rapld development, Industrially and politically. The Cerman population exceeded that of France by a wide margin and the latter very probably was afrald of a repetition of the attack of 1870 .

Irance began to look for friends after her terrible defeat by Prussia. She was rewarded in 1891 by making an alliance with Pussia. For France had money and Fussla had soldiers. Investments couzd, therefore, be made in Pussia which would help turn the wheels of Industry, and the French oould breathe easier because of the ourety of the hussian army. The Frenoh then faced the ruture 1 th confidence.

1. Hazen, Europe Since 1815, p. 357 . 
When in 1913 Poincare was elected President of France, the French nation was assured of a more vigorous pollcy on the part of the President then was usual. He indicated this within two days after his election by sending a message to Parliament. This perogative had not been exercised by previoug presidents. In this meam sage, he sald that he favored adequately safoguarding and Inoreasing the nation's strength, and closed with these words, It is in the service of this pollcy and maintenance of this unity in the future that I shall unfalteringly employ all energies". The President was a Iorrainian and, vexy naturally, he looked back to the land of his birth with the desirabllity of returning the lost provinces to Irance. In the same year of his eleotion to the Presidency he said. Mrance is not afrald of var". The French President was not alone in his att1tude toward Alaaoe-Iorralne. Wany of the people hoped that Irance might regain the territory they believed had been so wrongfully wrung from her. The tles of blood ere very strong. Juat as the French wanted the provinoes so Rusia was determined to support the Jugo-slavs in the Baizans.

In 1913 when Irance ordered three years training for Irench soldiers, a momber of the German Relchitag

2. Poincare, Raywond, The Tomolrs of Ravmond Poincare 1913-1914, Doubleday, Doran and Company, 1928, p. 16. 3. Gooch, Georgo Peabody, Iranco-German Heiotlons. Ionemans, Green and Company, Hew York, 1923, p. 63. 


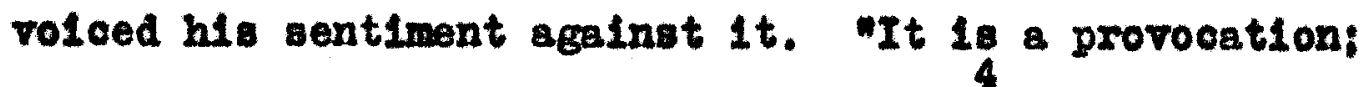
we w112 not allow 1t". ald the German.

Poincare's government was sparing no pains in preparing for any eventuality. The Irenchman had told Izrolsk1 shortly after the former's election in 2923 that he would at112 gulde the forelon polley of his country. Dp to the outbreak of the war Polncare succeeded very well. The Rusalans were gratifled, for they belleved they had found a man that rould back up Russia should there be a Russo-German war.

Poincare had visited Russia in 1912. He decided to make a visit in 1914 in his capacity as head of the nation. Jily 20, the France steamed into Cronstadt. In a few minutes the Czar and President were engaged in convergation. At the banquet that same evening the crar In his speech of weloome was hopeful that the combined strength of the1r two countries might continue in peace and even t1e. . more t1ghtiy the bands which unite them". Later while aboard the Irance, Polncare, in thanking the Czar for the graclous reception, declared that both countries were "animated by the same 1deal of peace combined with strength, honour, and dignty"." The Ozar responded in a closing message, nour concerted dipiowatio action and the brotherliness subsisting betreen our

4. Scott, D1plomatic Documents, op.e1t., Part I (The French Yellow Book). p. 533 .

5. Fay, op.o1t., p. 316, quoting Iirre lolx, I, pp. 203, 216, 266, 281 .

6. Poincare, Yemotrs, 1913-1914, op.01t.. p. 165.

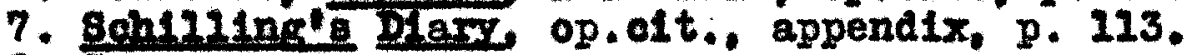

8. IBId, P. 115 . 
armed forces. . W111 21ghten the tasks of our respect1ve govermments....".

Having left sultable glfts for the nembers. of the farily of the Czar, Including the decoration of the Cordon of the erand cross for the helr to the throne, the Frealdent of the Frenoh Republic left the hoopitallty of the Romenoffs and the Irance steamed away from 1 ts noorings for the home port.

The Fnglish Ambassedor at st. Petersburg was Informed by sazonor the next day after the Irance atarted home that France and Russia were agreed upon the question of the balance of power, particulariy in the sast; that they would interfere if Austrla attemptod to attack the soverelenty of serbia, and on a reaffirmation of the alliance. ". . It almost looked as if France and Russ la were determined to make a strong stand ...". sala Buchanan to Grey.

As the Irence approached stockholm a w1reless message was reoelved aboard, sent to Poincare by the French Ambassador in st. Petersburg, announcing the Austrian ultimatun to Serbla. Polncare advised an extension of the time 1imit; also an investigation by the 10

Powers. The euggestlons were not accepted. Bazonov In Pussia sugeseted to Belgrade on July 24, that, the situation of the Serblans being hopeless, it would be

9. Buchenen to Gex, Ju2y 24, B.D., op.o1t.. Xo. 101. $\mathrm{gp}, 80-82$.

10. Poincare. Hoirs, 1913-1914, pp. 282-183. 
better for them to offer no realotance and to appeal to the Oxeet Powers". II Meanhlie, the Iranee came to anchor at stockholn. A message from the qual a'Orsay arratted the oblef. In 1 B Benvemumartin seld that Cermany supported Austria on the serblan ultimatim. Poincare did not prolong his Vialt to sweden, for on the twenty-sixth be was en route for Copenhagen. 13 He probably was encouraged to get away from the swedish cap1tal as early as hospltallty rould allow. For he heard alarming news from the Aussian Minister who sald. "It means war". The Irenchman replled, "It is terribie, terrible; for if it means wer for you, it most certeinly means war for us". Polncere ras unable to get additional news as he entered the last lap of his journey because of interference from the cerman wireless stations.

Sazonor now belleved he was standing on fixm ground or he never would have sald, on the day that Austrla orossed the serbian frontier, the order for moblizzation agalnet Austrla would be lasued". 25 He wa further assured by a message from the French goverment that Iranoe wa ready *. . to fulfill her obl1gations as an ally in case of necessity". sazonor was wo well pleased at the tenor of the note from France that he

11. 8oh1121ng'g Diazy, op.c1t., telegram, 10. 2487, g.33

12. Poincare, Lomolre, 1913-1914, p. 187.

23. Ib1d.. p. 193.

14. Bchuman, Mrederiak Lew1s, Far and Phplomeor In

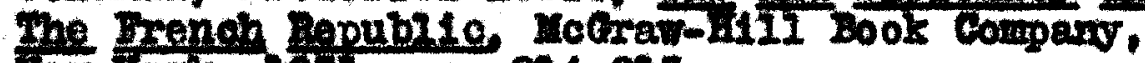
Iew Toris, 1931. pp. 214-215.

15. mftish bocuments, op.cit., No. 247, p. 162.

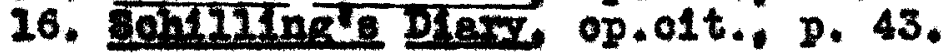


toleeraphed Iondon and Parte, It ony remalns for to to beten onr armol preparation and to reokon with the iner. 1tablist of war". 27

Prestent Polnoare and Viviant lended st bum

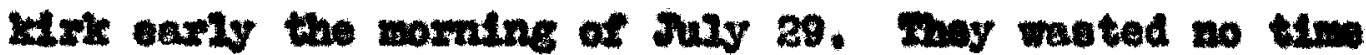
in getting to Paxis. Heve approvil of wasures made in their abeence was made; troops in training were oxdered to thalr utanding guarters; troope were oxdered to rotum from moosol and offlocrs on leave were told to return. The cablnot peesed to be united for purposes of derease. 18

The Preasdent, however, moved cautlous2y. Be recalled condtlene in 1870 then Iranee declared war 21ret. He savored waltine for cermany to move in order that Mussta and Iranoe might not be acoused of otarting the war. 29

The queetion nor aroes if the best wane of

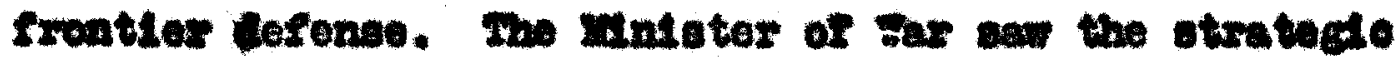

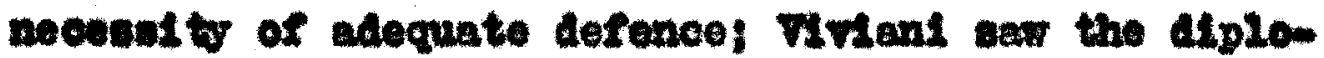
matle neoeesity of allowing no overt act to be som. alted ty Irance. Whe latter was copeolaliy intexested In courting the bood wil of medand who had not openis expreseed berwele about entering the wax.

A compremise betnoen the Var Induter and Hrians zeourted. Irtent advioed muben, Mronch

17. Ibld, p. 4.

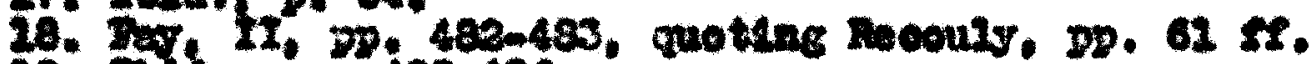
29. Iold., pp. $483-486$. 
Ambassador at Iondon that, ". . we have kept our troops ten kilonotres from the frontler and forbldden them to approach nearer". 20 Bo Erance approached the state of war.

W111 no one ralme a rolce agalnat the Impending svalanohe that is shortiy to amsh northern Iranoe? At least one man of considerable ablil ty does not hesitate. It is Juares from Beautiful Languedoe. He was a very Intellectual man, becoming a profeseor of philosophy at twenty-f1ve. Fe now eapoused the cause of the people. sociajiste of Burope were in Bession at Brussels. Juares in hls speech at one of the sestions declared the Cerman soclallate had been mentioned as the models for France. II thank our cerman comrades in the name of the Irenoh, and I swear: Fe W11I contirue to support them 11ke brothers agalnst the war-mongera. Attila campalga, true 6112 death". 21 Very shortiy thereafter he protested to his own govermment as a member of the Chamber of Deputiea against ite fallure to oheck Russia in its movements for war. Before another day had passed, ho had been killed by hussian agentB, it is clalmed. He had Iired as be suggested in his apeech in Brusse2s, "true t112 death".

20. Scott, Diplomatic Docments op.0it., I french Ye110m book). 10. 106, D. 663 .

21. G1 ted tudiris, op.c1t.. pp. 189-191.

22. Wichon Georges, rrance-Bims len AuLlence, the Hand11an compan, 1329, p. 285 . 
It that hour there wa every evidenos of the

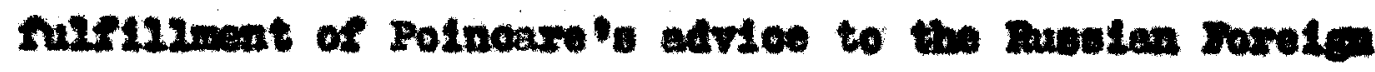

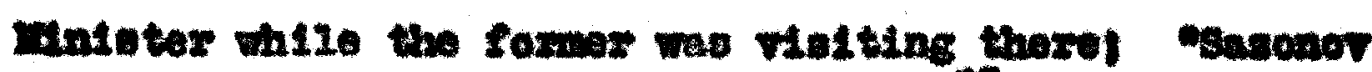
wat be 1 ras and we wuat aupport nim.

23. Fay, og, 01t,. II, p, 28R. 
Ghapter IX

Diplomecy Fallo 


\section{Chapter IX \\ Diplomacy Fails}

The suggestion was made by orey, even before the ultimatum, that Austria and Russia talk over the trouble arloing between Austria and Serbla. France, however, was unv12ling, for it was "very dangerous". Efforts of France and Russis to extend the time imit were unacceptable to Berchtold. Attempts to have four Powers mediate between Austria and Berbia were vetoed. Grey's suggestion that a conference of Ambassadors attempt to find a solution vere rejected. The desire of Austria and Germany to "local1ze" the confllot came to nothing.

Orey could not understend why Austria was untiling to make use of the Serblan reply as a basia for negotlations. For should diplomacy fail in this instance, Russle would be provoked and Burope would have a terrible war. Grey, therefore, asked Germeny to use her good off 1 ceg to enoourage Aubtria to accept the Serblan reply or at least use it as a starting point for conferences.

Bethmann decided that the time had come to act. He, therefore, sent a message to Tschlrsohky.

1. Ilohnoreky to Bethmann, telegram, July 27, K.D., 1.0. $258, \mathrm{p} .243$. 
"I request Count Berchtold's opinton on the Inglish suggestion, as likerise his vievr on Sazonor's desire to negotiate directly with Vienna", Bethmann sald in his message.

However, Berohtold had a reply ready, ". . since the opening of hostilities on the part of Serbia". telegraphed Berchtold, "and the ensuing declaration of war, Fingland's move was made too late". It was erident that Berchtold was in no mood to enter negotiations. For he had decied that wer mugt be declared in order "to out the ground from every attempt at intervention". Evidently, Germeny had a very lukewarm attitude toward the transmissal of Orey's request for reatraint upon her ally. The Austrian Ambessador bears out this statement, for he telegraphed Berchtold that Cermany Massures us in the most decided way that it does net identify itself with these propositions; that on the contrary it advises to disrecard them, but that it mast pass them on to satisfy the English government".

Just at this time the Kalser hurried back to Potsdam from his cruise. Bethmann, hearine that the Ealser was orderine the fleet home, rentured on the

2. Betbmana to Techirschky, telegram, July 27, K.D., 7o. 277, p. 411.

3. Trohirsohisy to Bethmann telecram, July 28, K.D., ㄱo. 313, p. 283 .

4. Prohirsohky to Bethmem, telegram, July 27, K.D., op.oit.. Ho. 257 .

5. Bzogyenv to Bercitola telegram, July 27, A.R.B., op.01t., II, Do. 68, D. 126 . 
t7enty-fifth most humbly to advise... no premature return of the fleet". The kalser upon receiving this message prote on the telegram, Unbellevable assumption! Unheard of: It never entered my mind!" ${ }^{6}$ In the meantime, however, upon the Kaiser's return, decision was made by him to suegest the "HIt in Belgrad" proposal. *. - Brery cause for war falla to the ground", sald the Kalser as he read the Serblan note. However, he continued, "The Serbians are Orientals; therefore, 1lars, tricksters, and masters of evasion". W12heim then proposed that a arantee that the promises 1212 be earried out" be required. In addition, the Austrian army could occupy a part of Serbia for a "temoorary" period.

Bethmann sent the mesisage as directed, but he did not make it very strong for he did not want to give offense to Austria and under no circumstances did he want to make $1 t$ appear that he was attempting to check Austria. For oixty hours he raited for an angwer to his message. When it finally came it wos a rejection. The Kalser, too, had sent a message to the mperor of Austria. "I should be honestly obliged to you if you would favor me w1th your decision as soon as posstble". sald the Kaiser. But the hope for a

6. Bethmann to tho Kolses, telegram, July 25, K.D., op.c1t.. No. 182, p. 201.

7. Wihelm to Jago: telegram, JuIy 28, K.D., op. cit.. Ho. 182, p. 201.

8. Wilhelm to Prancis Joseph, telegram, July 30 , K.D., op.c1t. No. 437, p. 371 . 
favorable answer to the "Halt in Belgrad" proposal was a.1 in rain.

In the meantine, Grey is busy in Iondon. Iichnomsis reported that the Hiniater was pleased by Germany's attempt to mediate between Austria and Russia. Grey was ready to enter into any discussions that might be hopeful of success. The Cerman Ambassador at Iondon reported that Grey had seld, "half in jest. that ve could never tell whose house might remain unscorched in the midet of such a consiagration as a World Var". On the thirtieth, Grey telegraphed Buchanan at st. Petersburg thet he favored the plan of conferences to settle the Austro-Serblan difficulty. provided the Austrians would evacuate any Serbian territory occupied when setisfaction was provided.

Grey next passed on the Russian formula. He belleved it involved too mich concession from Austria. For Austria was oalled upon to eliminate from the ultimatum anything infringing on Serbia's sovereion rights". Austria, too, wes expected to admit that her relations with Serbia were of Muropean interest. ${ }^{11}$ He asked Sazonov to modify the proposal. "If Austria", he said. "having occupled Belgrade and other Serbian territory, declares herself ready in the interest of

9. Ilchnowsix to Foreion office, telegram, July 29, K.D., op.c1t. Wo. 313, Dp. 357-358.

10. Grex to Buchanan, telegram, July 30, Scott, Diplomatic Documents, op.cit.. (Britioh Blue Book, I), No. 103, D. 965 of K.D., Ho. 439.

11. Kautsly Documents, No. 421, p. 360 . 
Ruropean peace to cease her adrance and to discuss hov a complete Bettlement can be arrived at, I hope that Russla pould also consent to discusaion and suspension of further military jreparativeg provided that other Powers aid the same". But these proposals went the way of all the others; they ended in failure for the Powers evidently did not trust one another.

At this time, it seems proper to notice events in another quarter. The royel cousins who presided over the affairs of Germany and Rissia st times sent secret telegrams to each other which they signed very affectionately. "Wi12y" or "Ilick". The series of sirty-five mesages were written from 1904 to 1907 . In these dispatches, which came to light as a result of the opening of the Russian archives, these monarchs considered various international topics. Tho Ralscr gave the Czar advice on nethods to be used to defeat Japan; arranged an alliance with the Czar that, had it remained in force, would hare nullified Russia's alliance with France and considered the crossing of Denmerk in case of war. Both scemed to be edpecially anxious to preserve the peace of the vorld; yet, both conjpired to thwart the continuance of peaceful morld relations.

12. Grey to Buchanan telegram, July 30, B.D., op. c1t. Ho. 309, pp. 196, 197 - also K.D., No. 460.

13. Bernheim, Herman, W111y-Hiclv Correapondence. Alfred hropf and company, hev York, 1918, pp. 15-18. 
With the strengthening of the bonds of the Intente nations on the one hand, and the cultivated friendahlp of the Triple Alizance nations on the other. the Kalser sart that he pould be unable to swing the Cari's councry over into his ermed camp, and so the correspondence so affectionately nurturcd for four yearg seemed to die, except that now and then a message of the old type may be found.

Then came the two shots at Scrajevo and the cr1810. The ka1ser's Government stood bock of the blank check" Eranted to Aurirla. The month quickly passed, and with it come the uitimatum. Sald the Kaiser wher he heaxd of the Serbian moblization, "This may result in mobilizetion by russia; w1II result in mobilization by Austria". 14 Additsonal proof of hor serfous W13:1am constderod condstions is to be found in the fact that he cut short his crise in the Horth, and he returned quickly and quisty to Potsdom, July 27 . Eut the Kaiser had arrived bock on the soil of the Fatherland to forecast posslble events; to recelve the latest reports eron his $013 \mathrm{y}$; and to keep both eyes and ears open on his eastorn and restern frontiers. He did not have long to wait before things began to happen. He, by this time, had read and digested the Austrian ultimatum and the Serbian reply. Recelling

14. Bethmann to Q17heim, telegram, July 25, K.D., op.c1t.. Ho. 132, p. 201. 
his previous experience in writing his part of the W111yMlcky correspondence, the Kalser resumed this correspondence the next day after the Austrian declaration of war upon Serbia. "It is with the Gravest concern". gald the Kaiser. "that I hear of the impression which the action of Austria against Serbia 1s creating in your country. The opirit that led Serolans to murder their orm King and his tife still dominates the country. I fully understand hov diffleult it is for you and your Eovermment to face the drift of your publio opinion. Therefore. With regard to the hearty and tender friendahip which binds us from lone ago with firm ties, I am exerting utmost influence to induce the Austrians to deal stralghtly to arrive at a satiafactory understanding with you. I confidently hope you will help me in my efforts to smooth over difficulties that may still ar1se. SIGNED: Your very sincere and devoted friend and cousin, w11y".

Wicholas at the same time remembered the very informal correspondence with his royal cousin at Berlin, and sent a telegram to his kineman in which he sald. "An 1enoble tar has beon declered to (oic) a neak country. - . To try to avoid such a calamity as a European war. I beg of you in the name of our old friendshlp to do what you can to stop your all1es from

15. The Mroeror to the Gas, telegrem, July 23, K.D., op.cit.. N. 335, p. 296. Also Sohililna's Diary D. 45 . 
going too far." ${ }^{16}$ The messages of the two cousina croseed on the wires.

William Immediately responded to the Czar's message, affirming his desire for peace and advising against any military movements on the part of Russia; for, sald he, that would precipitate a calanity we both wish to aroid and jeopardize position as medlator which I readily accepted on your appeal to wy friendohip and help".

The Czar was so heartened by this message that he cancelled the order for ceneral mobilization which was just in the act of being sent to borders of the far flung mire. This move, of course, caused the hearts of the Pussian General staff to skip a fer beats, and led them as has been oteted proviously to agree tacltiy among themselves that when they werc able to get the next order for gencral moblilzation that, "they would smash the telephone and disappear" for the time beine. The czar suggested next that, "It would be right to give over the Augtro-Serbian problem to the Hague Conference". The Kalser noted on the message, "We11!. Ve11! Thanks juat the same". Bethmann merely said in reply, "consideration in this case mould naturally be excluded".

16. Kautaky Documents, op.c1t., Ho. 332, p. 320.

17. Kalser to Gar, tolegrem, July 29, K.D.. op. clt.. Ho. 359; Schliling's Diary, p. 56 .

18. Kautsigy Doquments op.cit. Ho. 366; 8chilling's Diary, p. 54.

19. Bethmann to pourteles, telegram, July 30, K.D., op.c1t.. Ho. 391, p. 343 . 
The Xolser now was enraged at a telegram he received from the czar wherein the latter admitted that because of "preparations" by Austria they had decided partlally to moblilze "five deys ago". Whelm at this point noted, "I cannot agree to any more mediation, alnce the Caar who requested it has secretly mobilize: behind my back. Hy work 18 at an end".

Thus did the Willy-Hioky correspondence fall. Only a miracle oould save the vorld from the mighty avalanche of war.

Ueanihlle, the Knlser had a report from another quarter. Grey had expresged himself with vigor to the German Ambassador in Iondon on July 29. Ingland could "stand aslde as long as the conflict remeined confined to Austria and Fussia. But if pe (Germany) and France should be involved" . . Oreat Britain would be forced to make up 1 ts mind quickly". This information proved conclusively that Oreat Britain might flght. Consequently. Bethmann in informing the Cerman Ambessador of changed oonditions said, ". . We must urgent $2 y$ and impressively ouggest to the consideration of the Viema Cabinet the acceptance of mediation -...".

The telegram was read by Tschirsohicy to

20. Mlcholas to Ilinelm, telegram, July 30, K.D., op.c1t.. No, 390, D. 342 .

21. Kantgky Documents, op.c1t., Mo. 368, pp. 321-322. 22. Sautsky Documents, op.c1t.. No. 395, p. 344. 
Berchtold. The latter was "pale and sllent". Iater he cald he would take the matter to the Romeror. Plnally, the answer came. It was declded to "carry through the war against serbla and to order mob111zation one day earlier than had previously been decided upon. At 12123 P.II. July 31, the order for mob111zam tion w1th Francis Joseph's signature attached was sent on 1to way. August 4 was declared as the first day of moblilzation. 24

Conrad recelved heartening news from woltke Juiy 30. It undoubtedily cheered Berchtold, too, for It declared that, "The standing firm in a Furopean var Is the last chance of saving Austria-Fungary. Germany will go with her unconditionally".

23. Tachirschly to Bethmann telogram, JuIy 31, K.D.. op.cit.. No. 465 pp. 386-387.

24. Fay, op.c1t., II, p. 5i7, quoting schaefer, p. 536.

25. Ibid, pp. 507-508, quoting Conred, IV, p. 152. 
Chaptor $x$

The Agpoal To Armo 
Chapter X

The Appeal To Arms

Berchtold had won his point. It was now or never. Onless the Serblans rere checked in their aream for power their nationalistic aopirations would spread and cause untold damage to Austria. Should AustriaHungary lose her access to the sea she rould become a third rate power. That was a thought that was now seriously contemplated by Berchtold. On a number of occaslons in the past fer years, there had been causes for war. The Austrian Forelgn Minister would not be denied now. He had successfuliy plloted an ultimatum; broken off diplomatic relations; and co-operated with Conrad to mobll1ze the army. Year by year Rusala was getting stronger, and if 1 t was necessary to fight her Austria was ready to go all the way.

Francis Joseph wes not entirely w1 thout hope even then Giesl left Belgrade. When he recelved the nezs of the break in diplomatic relations he said in a choking volce, "Also doch". (So 1t has come after al1) Howerer, he still belleved that war need not necessarily ensue. 1 By July 31, however, he docided that there wa no escape from war and so slgned the order for mobilization, effective August 4.

1. Fay, op.c1t., II, p. 350, quoting largatti, p. 404. 
In a telegram to the Kaiser, the Amperor of Austria declared that he relled upon God, "combined with the certainty that the atrength of your defense w111 With unfinching fidelity, furntsh security for w Bmplre and for the Triple Alliance". The 1ssue betreen Austrla and Serbia mas to be settled by the appeal to arms.

Aussia did not hesitate long. She recalled that she had to bring in her troops from the far-flung ditricts of the mpire. She rould avenge her alplomat1c defeats in 1878 and 1908. She could not take chances on some other great Powers gettine possession of the stralts. She could not sit st11l and watch her Slavic kingmen in the Balkans be taken by Austria. For the nation who could control Constantinople and the Stralts would control the economic conditions of Southeastern Europe and the Bastern Mediterranean. Bren that nation would probably become the mater of the Balkans. Because of economic reasons, political policles, and, not least, because of ties of blood. Russia must not allow Austria to get a flrmer hold on the Balkane. The Russians considered the war. for the possession of the coveted stralts might be just ahead. They mast not hesitate.

Sazonov had looked over the fleld oarefully.

2. Irencis Jogeph to WLhelm, Ju2y 31, K.D., No. 482, p. 400 .

3. Stleve, Irledrlch, Isvolgky and The Forld Nar, Alfred Knopf and Company, 1926, pp. 187-193. 
He ant the ev1dence of a possible crash of the Dual Monarchy. He did not fall to notice that the expansion of Serbla must be 2argely to the Northward where so many of her kinsmen 1ived agalnst their w112 under the domination of Austrla Hungary. When Sazonov heard about the Austrian ultimatum to Serbla, he sald, Austria could not be both accuser and judge in her own cause". A fen days later fussla mobilized her arm. Russia vas ready for the otruggle.

Meanwhlle, Berchtold continued to look to Germany for assistance. Bethmann sald that "a very unimportant clash between the interests of Russia and Austria-Hungary may atart a wax". "The Falser expreased himself very effectively on the serbian question. He declared they were 11ars, tricksters, and could not generally be relled upon. The Kalser was moved to note In a telegram from the Ambessador at Belgrade oent July 24. "How hollon the whole so-called Serblan Great Power appears. That is the way all slar atates are! Only tread firmly on the feet of the rabble!" ${ }^{7}$ The Kalser had been called upon to stand behind hls "blank check". Fithein was not unmindful of the posaibilities in the Mear Rast". He had previously mode friends with

4. Ibla, D. 180 .

5. Teutsky Documents, op.01t.. Jo. 160.

6 . International Conolilation, German secret Iar Documents June 15 to August 5, 1914. I. 150, p. 204.

7. Ib1d, Yo. 150, Hay, 1920, p. 227 
the sultan. For politioal and economic reasons he favored a closer frlendship with the Turks. Both Austria and Germany had interesto in that part of the morld. Turkey was the traditional enemy of Russia. If then, Germany and Austria should fight fussia, opportunitles for trade would undoubtedily open before 8 them. When the Kalser heard that the Czar had taken military measures five deys before or July 24 , he was Infuriated. He was even aroused to say that the czar ". . mobllized behind my back".

sinee Germany mad the speed and Russia the numbers", 1t was 1mperative to Germany that the latter country should not be allowed to mobllize her forces from afar. It appeared that Ingland. France, and Russla have gareed among themselves.. . to carry on a prer of annihliation against us, taking the AustroSerblan confilet as a pretext", noted the Kalser. "The atupla1ty and clumsiness of our ally 18 thereby turned into a noose for ug". "The encircling of Cermany has now at last become an accomplished fact..."." Filward VII 18, after his death, stronger than I who am alive". 10

At this moment the Ka1ser who was at Potadam was intermupted by a telephone call from the Chanoellor.

8. Ib1d., p. 219.

9. Ibld.. p. 239 .

10. International Cono1liation, Geman Becret Dar Doouments, Ho. 150, Hay 1920, DP. 240-24I. 
Rugsta had 1ssued the call for general mobilization, sald Bethmann. The red placards calling the troope to the colors had been posted the night of the thirtieth. The Raiser's government immediately proclaimed, "threatening dancer of war". 21 Germany now tried to divert Austria's attention to Rusia principally, for Germany expected to mobilize 71 thin forty elght hours. 12 The declaration of Threatening Danger of war meant mob121zation. .... and this meant war". 13

Wilhelm then wired George $V$ saying he had just heard that Mloky has ordered the moblization of his whole arwy and fleet...". ${ }^{24}$ on the same day he sent a message to the Catar saylng that peace was st111 possible provided the czar rould stop moblilzation which mast threaten Cermany and Austria-Hungary". 15 A telegram fram the Czar to Wilhein came to the German Forelgn Offlde at 2:52 P.M., July 31. The messages of the Kaiser and Czar were crossing on the wires. The moperor of all the Rusolans admitted that the mobilization was the result of the movement of Austria, but he declared, "Hy troops shall take no prorooative action"

11. Ib1d.. g. 243 .

12. Bethmann to Tschirschlo, telecram, July 31. K.D., D०. 479 .

13. Protoool of the Session of the Roval Prussian Iinistry of state Juiy 30, K.D. . I0. 456 .

14. Whein to ceorae $y$ telegram, July 31, K.D.. 1. 477.

15. Wilhelm to Xlcholas II, telegram, July 31, K.D., 10. 480 . 
While negotlations with Austria are pending. Be thmann on the last day of the stormy diplowatic month of July gave Russla twelve hours to call off mobllization and declare it to Germany. 17 Russia refused. The scene mas very dramatic. Pourtalea asked sazonor three times to suspend miltary operations. Three times he replied in the negative. The German then gave Sazonov the declaration of war, and walking to the window declared, "I could never have belleved that I should leave st. Petersburg under these conditions". The next morning the German Imbassy was closed and Pourtales and his staff left for Berlin by apeolal train by the way of Finland.

At the same hour that Pourtales was learing st. Petersburg, the Czar was addressing his offlcers in church, "I salute in you wy whole army. I solemiy gwear not to make peace so long as there is a single enemy on Russia's 8011". 19 Fussia and Germany had entered the 118ts. They confliently loolsed for others to follow. The Kalser and the Czar now look to France. Will France remain 11 rm to the alliance fith Russia? The Kalser is hopeful ohe may not; the Czar devoutly hopes she w111 be falthrul. Cermany sent Irance an ultimatum. The time limit was later extended by tro

16. N1cholas to W13helm, telegram, July 31, K.D., Ho. 487, p. 402 .

17. Bethmann to Pourtales, telegram, July 31, K.D., 15o. 490, p. 404 .

18. Sahiling'g Diary, op.c1t., pp. 76-79.

19. Buohanan, teorge wiliam, iv Mission to Bussia. Iftile, Brown and Company, Boston, 1923, pp. 211-212. 
hours, and even then the fermans walted, hoping againgt hope that France would remain neutral. In the message to the German Ambassador at Paris, Bethmann instruoted the former to insiat that Irance, In the event she chose neutral1ty, turn over the fortresses of Toul and verdun to Cermany. These she promised to return to France at the close of the war. If schoen mentioned the fortresses in his conversation to the French, Vivianl did not say so. Irance, however, had no thought of ataying out of the par. Since 1922 Ausela had known she could count on Prance in case of war. France reassured Russia during the orisis and announced rery definitely on Auguat I that she rould stand by her.

The Brenoh government, however, wanted Gerwany to declare war agalnst Irance. It would mako the Irenoh come to the colors more patriotically. Sound "diplomatio ph11 sophy" Indeed! But the Brench President wanted the Cermans to start the war for other reasons: (2) It would be necessary to get the approval of the French Parllament; (2) he did not want to answer questlons about the Fussian all1ance; (3) Inglish opinton mist not be mede unfarorable to France. Consequent2y, France gave no answer to the German ultimatum but sho did

20. Bethmann to Sohoen telegram, July 31, K.D., 10. $491, p, 405$.

21. Soott, Hiomatic Documents, (French Yollow Book) Io. 120, Dp, 675-676.

22. Dlokinson, olting Romberg, p, 38, 10. 222, p. 60, I0. 225. Informetion herein olted was not in R.O.B. as published in 1914 . 
mob111ze August 1.

Heanwile, Iovolsky arked to wee Poincare near midnight August 1. "Germany has declared war on Russia". he sald. What w111 France dop" The Irenchman replied that he would call the Ministers together "and they w111 surely fulfil our allianoe obligations".

Baron Schoen, speaking for Germany, threw down the gauge of battle to Franoe August 3 . French aviators had flown over Germen territory, he sald. They had also violated the neutrallty of Belgium by elyine over a part of that country. "... In the presence of these acts of aggression". Schoen sald, - the German Ruplre considers 1 tself in a state of war with Brance...". The long perlod of secret diplomacy had ended in wer.

It is sald that ood was also moblilzed. Brenots Joseph feelingly sald, "I an consolous of the momentous character of my decisions and have taken them trusting in God's juatice". The Kaloer iffed his face heaven-ward, too, as he aent the message to the aged Imperor, "I Join wy prayers wh yours that God may stand by us". The Czar, as had been suggested before, declared in the presence of the German Ambassador,

23. Polncare, Yemo1rs, 1913-1914, p. 272. 24. Polnoare, Lemolrs, 1913-1914, p. 272. 25. Boott, Diplomatic Documents, I, (French Ye11 i Book, WO. 248), D. 694 . 
26

"Onty one can help us." And so Involing God's name, the nations go to war. Snall wonder that Napoleon sald so long ago, "God is on the side of the strongest battallons".

Trua did the nations enter the 118ta; the Czar signed the decree that later led him to violent death In 8iber1a; the Kalser by his action in these hot sumer days led him to exile at Doorn to satrood in retrompect. Jrancis Joseph ol coed his last days in the holocaust of war; while Irance in the next few years wes bled white with her saoriflces on the Findenburg 11ne.

26. Iudw1 g, Ju2y 14, op.c1t., p. 203.

27. Co1. Irederiok Pelmer, Treire Deys That Wrecked 4 Dor2d, The Courier-Journal, August 2, 1934. 
Captex $\pi$

Ingland And Bezédum Thter the Var 
Yany belleved that Bngland held the key that would unlock the door elther to peace or to war on those summer days of 1914. For this bellef there are a number of reasons. Of all the Inropean powers who entered the war, Great Britain, perhapa, had 2e日s interest in the Balkan peninsula than ary other. She would, of course, expreas some concern as to the ownership of Constantinople but as Iong as Russia or some other Grest Power ald not make an attempt to take that ofty, she would certainzy make no objection to 1 t remalning under the control of Turkey. It is easily seen if the atatus gue was to be maintained, that 1t was far better for the atrategle at ty of Constantinople (Istanbul) to remain under the weak Turks' control than to pass into the hands of a strong nation.

Iater, Great Britain ohanged her mind about the owmership of Constantinople. When Oreat Britain at taoked the Dardanelles in the Var, Russia believed that Ingland wanted to prevent her from getting Constantinople. Bazonor was believed by some Russians to be the tool of Britain. It seomed necessary to gave Bazonov's position and polloy and to prevent serlous wischlef". sald erey that Russia have the promise of Constantinople. Grey admitted that neither Great Britain 
nor France manted to make the concession. But, according to the Britioh Foreion Hnister, the Russian Losses in the comon cause led Rngland to be the first to make the concession. "The Irench agreed; the thing was done". As the crisis approached in 1914, It seemed evident that Great Britain would be unconcerned with any Austro-8erbian war, except as the peace of Burope might be affected. The Britioh vere not tied by a strong alliance to elther alsputant in the Austro-Serbian crisio, although they belonged to the Iriple Mntente. Maturaliy a nation that had no particular interest would be more Iikely to see that there frere two sides to the dispute. The British fleet, too, weo somethine with which to be reckoned, and if auch a powerful nation had taken leadership and had made more definite suggestions to these powere who vere about to flght, most 21kely they would respectfully 11 sten.

So, because of these facts, France and Pussia asked that Creat Britain restrain the Central Powers by declaring in no uncertain terms that if the avalanche descended that she rould quiokly come to the ald of the Entente Powers, Oermany, 11kewlse, called upon Iord Crey, British uniater of Boreien Affairs, to prevent hussia from doing anthing rash.

It will be remerbered, however, that Creat

1. Viscount Grey of Fallodon, Menty-Bre Yeara, 1892-1916, Frederick A. Stokes Company, 1925, II, DP $187-188$. 
Britain has the demooratic form of goverment; that erey oould not move very fast unt12 Parllament approved the general pol1eles. In addition to that point, the cabinet was not sure where it stood on this crials in 1 ts ear2y etages.

It seems, too, that crey was occupled by other considerations. The Iriah question was st111 a troublesowe one to Oreat Britain and needed immediate attention. Anglo-German relations were better than they had been for years. Crey had been able to smooth the troubled vaters of suspioton in offictal Germen minds on the question of Closer Anglo-musian naval relations, to the mutual satiBfaction of both Creat Britain and Cerwany. The British eleet had just completed a vialt to the Kiel oanal, where they had been entertained in royel faahion by their cerman kinsmen.

Mevertheless, Orey began to take an active part when he saw that the worid's peace was menaoed. AII the ouggestions made were unavaling. It is a diffleult tagk to get four or flve Powers to agree, especlally when there are at least two broad lines of cleavage between them, and when oftentimes cross currents of one kind or another exlet.

2. V1scount Orey of Mallodon, Irenty-Mre Years, 18921916. I, p. 293 .

3. Cantain Eenderson's Report, Juzy 3, B.D., No. 7. 
The early suggestion of Grey on "direct converations" was dropped, for France declared thls was "very dangerous". France was evidentIy afrald that Austrla might get the better of Russia in a diplomatic encounter. whe thought that wuch a position might indicate to Cermany a lack of solldarity among the intente. The proposal of extending the 11mit placed by Austria on her Berblan uItimatum 21kewise came to naught, because it takes time for telegrams to be exchanged between natlons, and, too, Austrie did not take kindly to the 1 dea.

The suggestion that fussia and Austria settle their difficulties by mediation, while acceptable to Cermany, was turned down by Irance who thought that Austria and Berbla should settle their difficulties first. noreover, Russia was "very apprehensive" that the Cermans might think the Batente Powers were not standing together. When Orey suggested that the Ambassadors of the four Powers sit down in conference together, this plan was rejected because the plan of "direct conversationg" between Vienne and st. Peteraburg was broucht forwara. However, Berchtold objected to this last plan. and rery quickig war between Austria and Berbia followed.

mroughout the se critical days both the Batente nations and the Teutonic Alliance attempted to discover what Areat Britain would do. Grey was encouraged to throw

4. Day, op.01t., II, pp. 400-401. 
the weight of Bngland's resources and Influence on the belances with Irence and Pussia with the 1dea of forolng Germany and Austria to refrain from war. Jaturelly, the Central Powers hoped Creat Britain would maintain neutrallty. Dickinson thinks it is questionable whether a bold pronounoement by Creat Iritain early in the controveray would have prevented war.

Bven the Presldent of Irance on July 32 declared In a letter to KIng Ceorge $\nabla$ that if Gerweny were certain that the Britiah Government would not interrene in a conflict in whlch Irance would be engeged; war would be Iner1table", and ". . If Cermany were oertain that the Intente Cordlale would be operative in such case, even to the battlefleld there would be the ereatest chence that peece would not be broken".

But the Britiah were not ready at the last of July to throw the weicht of her Influence and the otrength of her grand fleet Into the struggle. Both in 1906 and 1912. the Inglish had regerved the right to enter or remain neutral in a possible Franco-Cerman entanglement. They. therefore, did not enter the Far on snap judgment. As ear2y as the loroocan ortals of 1906, Irance was disturbed at the possibility of a Cerman attack upon ber. It was so serious that the Ga1110 nation asked Great Britain if. In the event of an unproroked attack by Cermany, Great Britaln would aselat her repel the

5. Poincare, op.eit., p. 245. 
Invas10n. The French deolared that Great Britain could not render armed support when the time came, unless some corversations have already taken place between naval and miltary experts". IIr Edward brey conceded the logle of the French suggestlons and authorized the conversations, It was understood, however, that aw discusslons would not bind or restrlot elther government in Ite freedom to make decialons on the question of support when the time came.

Viscount Faldane, Britiah Var Minister in 2906, oorroborates the testimony of Bir EAward Crey on FrancoMr1tish miltary discussions. Orey conoulted the Prime Iinister, Chancellor of the Irohequer, and War Mnister In 1906 on the problem as to whother or not they could put 100,000 men in the fleld on the Jranco-Belgian front1er In case the Berman arrus should attack Irance by the way of Belgium. Viscount Haldane was instructed to initLate negotlations with France. 7

By 1920, with both 81r Douglas Filg and Bir

John Frenoh assisting, the roorganization of the British Aruy was completed. It was possible then to place 260,000 troops in the f1eld, and within twelve days have the troops in the proper place.

6. Wscount Crey of Bellodon, 02.01t., Bpeech by 815 Edwerd hey In the House of Commons, Auguat 3, 1914, II, Appendi $x, \mathrm{Dp}, 310-312$.

7. Viscount Faldane; Murope Before The Dar, Dunk and Vagma11s Compeny. Lev Xork. 1920, p. 45.

8. Tb1d., Pp. $47-48$. 
subsequent events proved that the British hed made their pre-var organization effectively for August 3. They mobillzed their entire zrpeditionary Force, consisting of approximately elght divisions and began to more them across the channel upon the declaration of var.

Perhaps no one would serioualy question the fect that a navy was essential to the protection of Creat Britain. It was rery necessary to Britiah plang that no greet Power controlled the Iow Countrles. Fox almost a thousand years the Britiah have watahed the territory across the channel. The Bundred Year War, the attack of the Spanish Armada, the Ingligh trouble with France in 1793; all bear testimony that history as vell as geography Indicated the concerm of Creat Britain over the destiny of Belgtum.

The Iritiah Far Miniater declared in his historic speech to the House of Commons August 3, 1914 that the chief faotor in Britain's attitude toward Belgiva was the treaty of 1839. Franoe and the Cerman Confederation had observed Belglan neutrallty in 2870. This treaty was founded not only out of consideration for Belgium . . Dut in the interests of those who guarantee the neutrality of Belglun". 11

9. Ibld.. P. 50 .

10. Seymoux, Gharles, The Dlplomatie Baokeround of the Der. 1870-1914. "Tale univerelty Press, lew heren, p. 277 .

12. Tisoount Erey of Jaliodon, Mrenty Mre Iears, 1892-1926, Appendix D, D. 318. 
But wh chould ary creat polnt be made about Belgtum It Is ouch a wall country, yot so geographlvaly laportant as a part of the plain leading toward Par1a, and a country that has a great deal to do wh the wouth of the Dinine. The Gerwans, of course, called the Itver the Cerman Fulne. Ifstorically, It had been a bane of contention between seuton and Iatin for approximately ten centuries. Ineland, too, had her interests, for the Tetherlands were too alose for her not to bhow gemine interest in possible abanges in the low oountries.

The ILtt2e country wa in a strategle 20cation. To offoet any attempt by a exeat Power to take the oountry. Prusala proposed in the slrat half of the ninoteenth oentury that the states that had a speclfio interest in the Belgtan section declare Belgivm a neutral state in perpetulty. Creat Britain, Austria, Irance, and Musia were wiling. Belgiwn, therefore, acoording to the treaty of Iondon, 1839, was formed an Independent and perpetralyy noutral otate if 1 t chall be found to observe ouch netw trallty toward all other states". 22 whis neutrallty was guaranteed by the ereat Powerw which, at that tine, vere Irance, Creat Britaln, Austria, Prussie, and Bussta. Thls moant that no Power could cross Belglum to attaok Folland. Ielther could Folland cross Belgtum, nor oonld any other Power Vlelate the territory of Belgtum by troop worement. A seeret arrangement between Belglum and the 
Powers other than Franoe provided that in the oreat aw of Belgtimin fortreases ahould be attacked that the other Powers alematory to the document would came to Balgtum's ald. It veems erident, therefore, that should any one of the other Powers attack, the King of the Bolgtans would call on the other four Powers to wee to 11 that the territorlel ptatus and the dignity of the nation remains untmpatred. 23

The evil of rlolating Belgtum's noutrall to was greater in 2914 than it would have boen in 1870 for Cexmany was much wore powerful. "If her neutrall ty were Volated", sald brey. "and the riolation oubultted to by Bolgtum and sequlesced in by her guarantore, hor independenoe was cone forever". When 1 t became apparent to the Brittion abinet that Cerwany was golng to Violate Belglen noutrallty, "they began all to face the sam wa", sald Blr Edward erey. For we had our backe to the same straight wa12."

Germany had been told by Mocount Daldene in 2012, that irf Franoe were attecled and on attempt ade to oocupy her territory, our neutrality mat not be reokoned

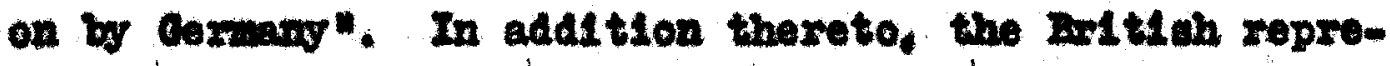
sentative told Bethmann that Creat Britain wos bound to

13. 7old.. PD. 349-360.

24. Veocunt erey of Jallodon, op.o1t., Ix, pp. 8-9. 
aselet Belgtum in case of Invasion". 15 on July 32, events began to move rapldy. Creat iritaln adked Iranoe and Germany on Jury 31 if they would respect Beletan neutrall ty, provided no other Power riolated it. Grey sald to Belglum that he presumed the latter would "do her utmost to maintain her noutrall ty". Beledum did not hesitate to say in her reply to the British Forelgn Indster that. . . Great Britain and the other nat1ons guaranteeing our Independence could rest ascured that we would neglect no effort to waintaln our neutrals ty, and that wo were comvinoed that the other Powers would reapect and malntain that noutrality". 16

Iranoe angwered the Britlsh eommintoation relating to Belgian neutrality by saying that oho would reapect the noutrall ty of Belgtim, and it wowld only be In the event of some other Power floleting that neutralls that France mifht find herself under the necesalto. In order to asaure the defense of her securit to to act otherm wise. 27 The Irench govemment assured Beletum, too, of her deslre to maintain the Belefin neutrall ty. The Goxman secretaxy of state lald to the Britioh Ambasedor that he wat consult the Juperor and the manoellor before be sould posalbly anerer".

15. Heoount Ealdane, Before the Jas, Junk Wagnalis Oonpary, Iet Tork, 1920, D. Ys.

16. 80ott; op. oft.; (Belghan trey Book, I, Io. 12)p.366

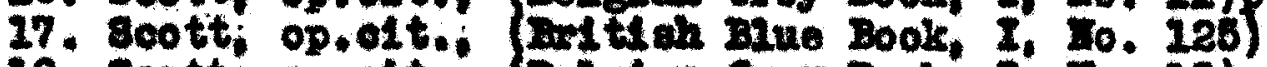

18. Boott; op.oft.; Bolgtan Gey Book, I. Z0. 1B)

19. Bcott, op.oft., (Ixitish nue Book, I, I0. 122) 
De sald, turtherwore, that an anower mi cht dis20

alose to a cortien extent a part of theix campalgn". W0 new know that a note had been gent by Germany to hor Mbassador in museele tro days before, declaring that France might attack through Belgdim, in whioh case carmany cextalny would reserve the rlght to go to war with Beletun if the latter offered resistanoe to the German plans.

However, Bolgtum"s neutrall ty had been guaranteed by the treaty of 1839. It had been observed by tho Carwan atate and rrance in 1870. The Hague Convention of ootober 18, 2907 contalned alear pronouncemento applying to neutral natlons as follows whe texritory of noutral Powers is inviolablo". (Art. I) "Belligerents are forbidden to move troops or conroys, whether of muntions of war or of oupplies, ecross the territory of a neutral Power". (Art. 2) The fact of a neutral Power resisting, oren by foroe, attempts agsinst its neutrall to camot be regarded as a host11e act. (Art. 10)

Murthermoxe, it is Ilkely that Belgtum was anrare that ceneral Bchlieffen In 1894 abandoned the Idea of an offenolve sgainet Rusale should war agalnot the Dual Allamee arlae. A method of attaok known as the

20. Gonchen to Gev, telegran Mugust 1, B.D., Ho. 385.

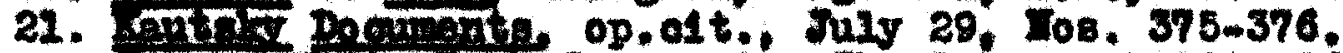
22. Corman Hate hon conoerning the Reoponsibllity of

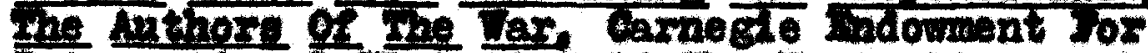
intermational violation of the Deutrall ty of Bel-. Gum and-Inxemburg Peace, Oxford Oniversity Press, Iew Tork, 2924, p. 22 . 
Bahleffen-loltice plan plan provided for the Invaston of Franee through Delghw. Fhoy thoucht they oould defeat the French armies $\mathrm{II}$ thin $\mathrm{aLx}$ weeke and then move the Cerman arrales to the Iusalan frontler to ohook the Buseian onslaught.

The German General staff, 21kem1ge, In 2913 declded that if war came that more then huesia would be involred in 1t. So Voltke decided to take a chanoe; cross Belgtum, and In alx woeks defeat Irance and be able to move his troops to the eastern frontis to recelve the onsleught of the Dussians whloh would come at a later time. It wos a selfmevident faot to all milltary nen that hussis could not moblilze her troops rapldis due to poor roade, lack of suffletent rallroade and the onormous extent of her country.

In addition, even a cavual observer in BelGive could have seen the Cerman rallroads bullt up to the Belgtan boxdex. The same observer could easlly have known that the topograply of the Iand on the IranooGezman frontier was not eonducive to a rapid movement of Cerwan troops Into Irance. If could caslly have obserred that, in short, it would be much oasler for Germany to attaok Irance through Belgium than to take a more souther2y route. In view of these facts, "Belgtwe put her army on 1 ts reinforcod strength". July 29 . Bhe

23. Somptt, op.o1t., II, p. 263, ofting Der Extverea, I, D. 27. 
notifled the Powers together with Eollend and Inxembers 24

of the developmant. She did not wilh to be ceught napplang.

Belgtwe seemed not to be afrald of Irance. In a conversation at kruseels July 31, between the Ironch Minister and the Bestan Minister for Jorelon Affalrs, the Irenchman declared that ". . no incurelon of Irench trooge Into Belglum will teke place, even if cosm alderable forces are mased upon the frontlere of your oountry. Irance does not with to incur the responstbllt ty so far as Bolgtum is conoerned, of taking the flrst host120 step". At this mowent. Belghum belleved the Cerman attitude would be the sane as that of the Covermment of 28

the Frenoh Republic. To be on the safe olde, homerer, Beletwe moblized her army. suguat 1 . 26

$A$ varning to Cerwany of what wight happen in Ind and could eas12y have been read into frey's massage to the Gexman Amassador in Iondon, man he suggested that if there were a rolation of the neterallty of Boletum by one combatent while the othor observed it, it would be extremely alfelcult to restrain publio feeling In this country". Imediately, Grey nte, the Ambobedor alked him is exmang gave a promise not to riolate Belgten neutrallty, would we engege to remaln noutralp"

24. 80ott, 0p.01t.. I, (Boigtan Grey Book, I, I0. 8) p. 364 .

25. Ibld.; (BeIgten Exey Book; I; Io. 9), p. 364 . 26. Tb1d.. (Be1gten Erey Book, I, Io. 10) p. 366. 
To this, Grey replled that wour hands were st111 iree and we were considering mat our attitude ahould be". The Britieh Forelgn Ministex thon went on to say that it partialy cepended on public opinion what they would do, but that whe neutrall ty of Belgalum would appeal very -tronely to public opinton here". Io Indieated they couzd not "give a pronsse of neutrall ty on that condition alone". Tho cexwan then asked wat conditloas ingt keep Great Irttaln neutral. Fo even asked if the guar. antee of Jrance and her colontes would keep Bettain pewtral. Thereupon, exey sald he could not tpromed to rematn neutral on elmilar terms . . " and closed the ilscusstion by sayine, wo wast keep our hands troen.

Whon it appeared to loltike highy probable that war wowld follow rexy shoztly after the huselen "partial moblilation" plan, ho set to work to eo over the plans for a posalble campalon. It was extremely necossary according to the plans that pezefun did not attempt to block the path of the temen troop wovesunt.

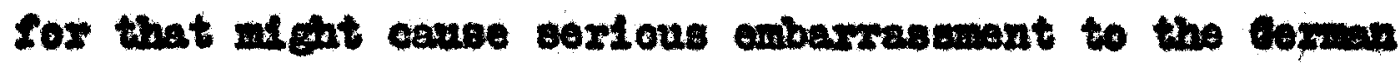
cavas. It so happened that the plan oalled for the movement of the cermen xleth wing to proesed throuch

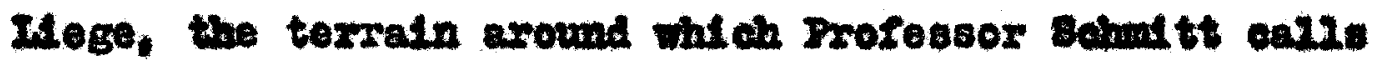
a bottle neok. 28 Foreseelng possible alficultes 27. soott, op.git., II, (Britlah skue Book, I, I0. 283) $\mathrm{P}, 984$. 28. Sohnt, op.ott., II, p. 249. 
here. Folthe and Indendoret some roars before had arranged to move ahook troops so raplaly into this reglon that the Beledans would not have time to get thols defenses ready. 80, on July 26, Do2tke, himself, arafted an ultimatur for Belgiva, to be handed to the Bolgtan authoritles at the right woment. The final document based on Ioltke"s draft was rent, vealed, to the Coxwan Inister In zurssels on the twenty-ninth, and the oxder getren that thits mesage mat be kept under locir and

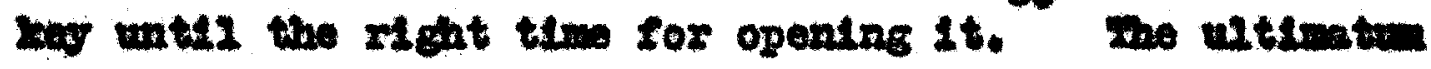
atated, that Irench foroes Intended to . . Earch agninst Gesmany through Belgtan temitory . . . Tho measures of cermavy"s opponentr foroe her, for har ow proteotion, to onter Beledan territory". Murthemore. scoording to the ultustum, chould Beledum offer restst-

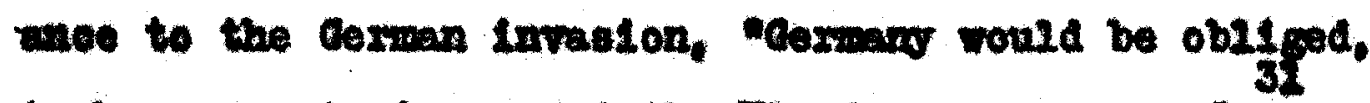
to her regret, to regard the Ingdom an an onow:. Internstional lar does not justiry the breach of a treats by one country to forestall ano thex steto who contemplated the sam act.

Auguet 2, Jagow oxdered Ton Dolow at Druecels to open the ultimatim int ch had boen dellvered to hin a fow davs before; make tow changes; and egpecially moles

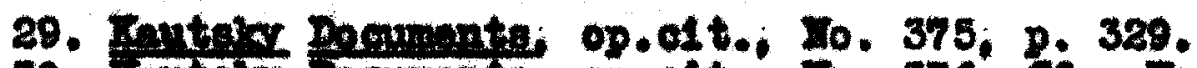

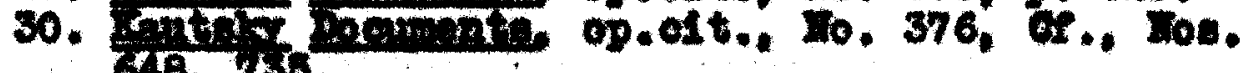
$648,136$.

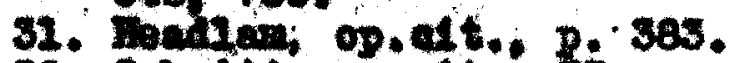

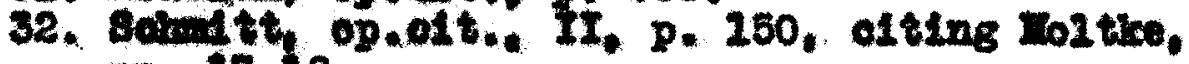
pp. 27-18. 
the Impression on the Deletans that all tho information

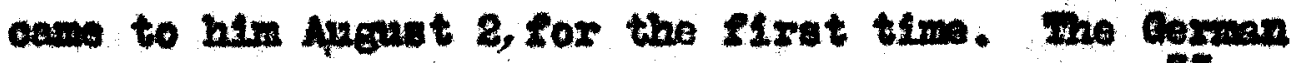
ultimatur carriod a time lint of tweIve hours. Cermany cemanded passage for her troops through Delgtum. the sald her Information Indioated that there was mo coubt as to the intention of Irance to nove through Dalglan terr1tory", who Gaxman trooph wat, therefore, enter Bezgtum.

At 7 A.I., Angust 3, Delgtum declared in her anower to the cermen uItimatum that mo atrateglo interest Justifles ouch a violation of international Iaw. tho Belgtan foverment, If they were to acoept the proposals oukatted to thes would sacrifloe the honor of the nation and botray the1r duty toward muxope". They ald not healtate to declaxe to Germany that they were - alumly resolved to repel by all the moans in thelr perrer every atteck upon their rights".

Ing Albext next appealod to ring ceorge of angland for alplomatio intervention . . to sefeguard the Integrity of Beletum". 36

Cermany notifled Beiglue that at 6 otolook, Auguat 4. einoe Belglum had rejected Cezmany"s well

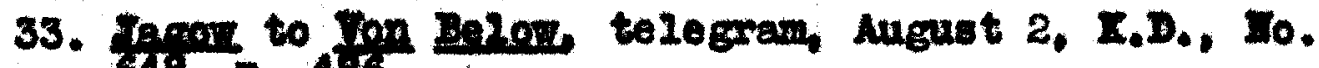
646.8 .466$.

34. Boott; op.01t, I. (Belgtan Grey Book, I, Do. 20).

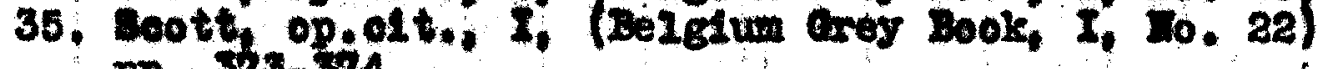
DP. $373-314$.

36. Ing ubert to King Geprea $\nabla$, telegram, August 3 .

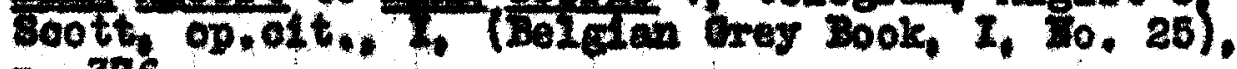
p. 376. 
meant proposale" they would have to proteot themselves aganst the Irench wenace "oven if we have to do it by force of arms". In A2bert's reply to the ultimatum,

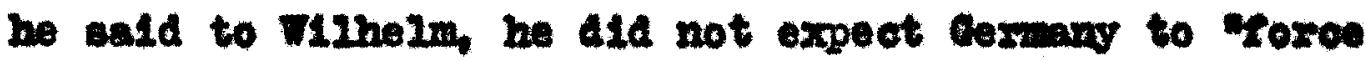
us, In the face of all Burope, to the cruel chotoe between war and dithonori between Ildexty to trogtles and falthlessness to our internal obllgatlons".

shortly after 6 A, X., Augunt 4, German troopa entered Beledan territory. The Corman Inister of Forelen Affatrs declared the passage through Beiglum was a questlon of Iffe and death" to Cormany. Spocidng to the Balchutag, the Chancellor mald, Mentlemen, wo are In a btate of necesal ty and necesal ty know no Iaw. The orosing of Bolgium is a breach of international Law . . ." "the wrong - I epeak openzy - the wrong we thereby comblt we w112 txy to make good as woon as our miltary alm have been attalnod". It who is monaced, 20 we are, and is flghting for his all can only constder how he is to hack his way through". 39

Count Von Ierchonfeld supplemented the Gance120x'B renariss when he stated the Corman Beneral stare thought it necesnary to erose Belgatum Jrance can only be mocessfuly attacked from that slde. At tho risk of

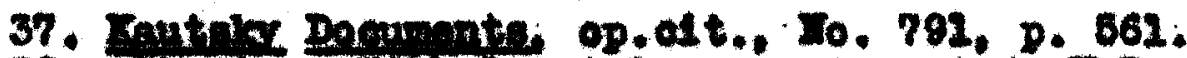

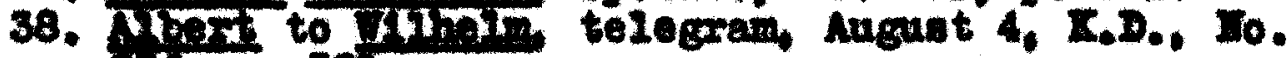
es6, p. BeI.

39. Cexwan int to Dook, op.o1t.. p. 24, quoting Bath

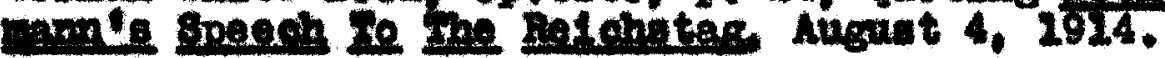


bringing about the Intervention of Ingland, Cormany cannot reepeot Beledan neutral1 ty". A Lttle leter in the dor. August 4, Bezclum appealed to the Intente for thelr 00-0peration. The Gexwan troope had entered Belchun. Belediun handed Von Bolow his pasaports at once. And so in the face of most desperate odds, Belgetum, wose territory could be lald down elcht times in exeat Brltain and whose population would not oven equal that of Creater Iondon, went to war againot a nation tho had opread the soepel of hor Invinatble armites.

Belgtum and Gerwang were at war. Dould Ingland hold alools Coxwary awalted the posalble Inglish aotion breathleas2y. Jranoe was hoping that Beftain's navy wight soue to her resene. Folther had to walt long, for on Angust 4, Britain relleved each of them by the strangth of her ultimatum eent to the Cermang. To the termang it meant exier, to the Irench, hope.

At 20:30 A.I. on Angust 4, Brey sald to Belm glum that Ereat Britaln would Join Musela and France if necessary to absist Beletum in resisting the use of force by Gerwany against them. She further guaranteed "to malntaln tholr Independence and Integrity in suture gears". 43

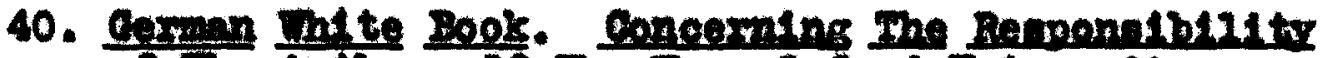

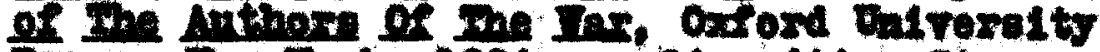
Frese, Iew Toxk, 1924, p. 24, elting stenocraphe-

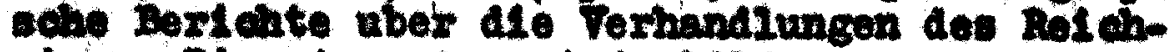

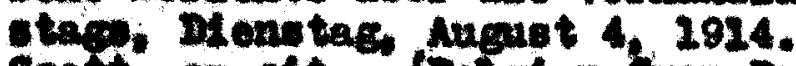

42. Beott opedt., (Baigtan treg Book, I, 20. 32) pp. $379-880$.

42. Tbid. Io. 42, D. 387 .

45. Grert to Bertle, telegram, Angust 4, B.D., Do. 38, p. 378 . 
At 9,30 A.X., August 4, Ingland demanded that

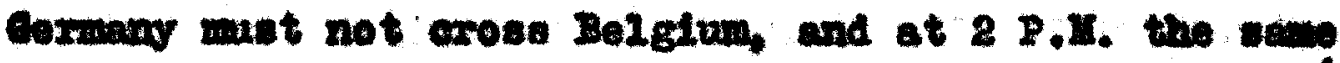
day. sho demanded an enover by 12 o'olock that night. When no responoe calne to the witlmatru, both Germany and Ingland lmev this meent war. In a conversati on between Jagow and Goschen the former declared that "they (Germany) bad to advance Into Jranoe by the quideses and eavieat way . . It was a mattex of Iffe and death to them". ince the southern route wouzd have ombed I08a of time. Coschen then asked to see the Chancellor before he demanded his paseports. The imbessador says that the chancellor harangued hin for about twenty mimutes. Junt for a word 'noutrallty'; Just for a sorap of paper", cald

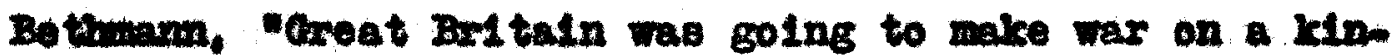
dred natton who destred nothing better than to be Irtende 45 It th hor". Coschon said, in reforring to the remark that cerwany considered it "a matter of 11 fe and death" to get acrose Belgtum quiokly, "that it was... a matter of 11 fe and death for the honor of areat Britain that she vhould koep her solem engagement . . . . At

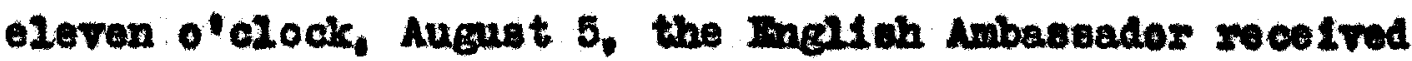
he paseporta and the day following left for Iondon by the way of Dolland.

44. Intien poouments, op.01t., Mos. 573, 504. 45. Sabmitt, op.01t.. II, p. 363, quoting Betheann's

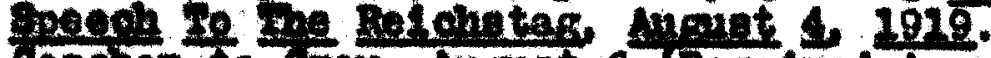

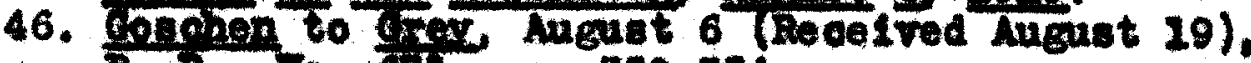
B. 3., 20. 67L, pp. 350-354. 


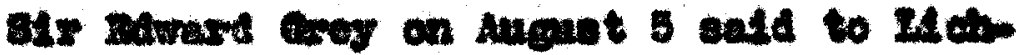

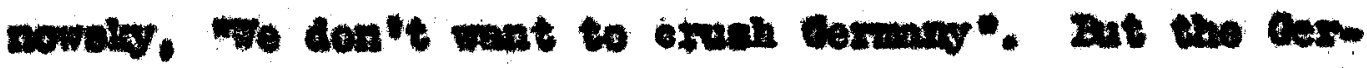

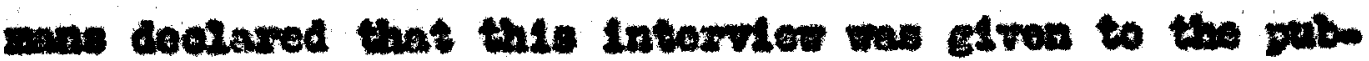

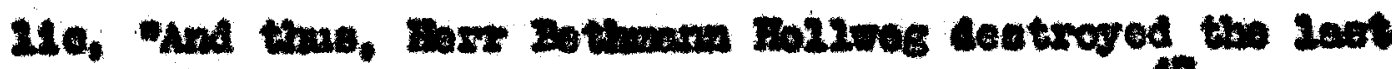

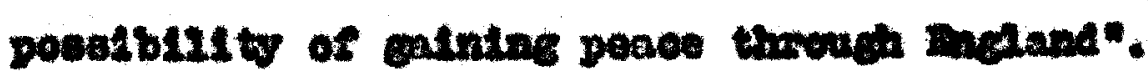

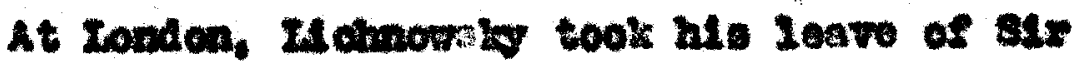

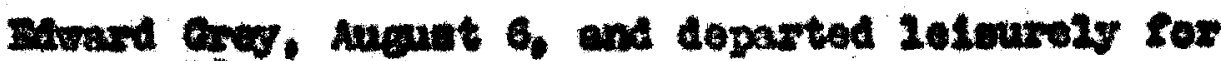
48

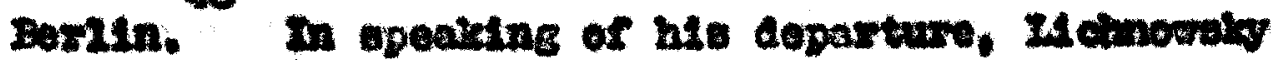

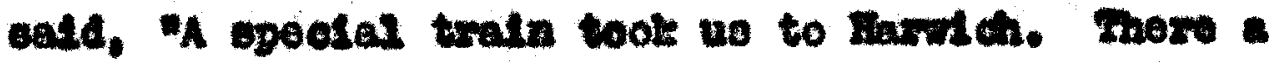

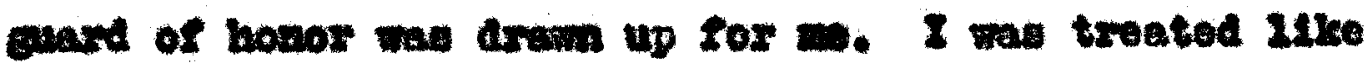
a departing sovervige, Buch whe the ead of wo Ionton mevion. It was woolvod, not to the ar2es of the

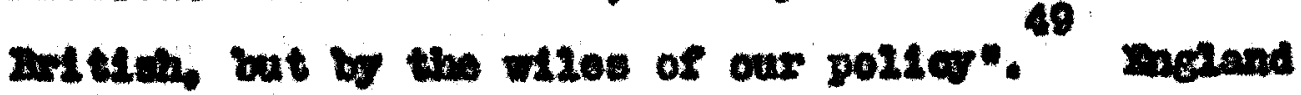

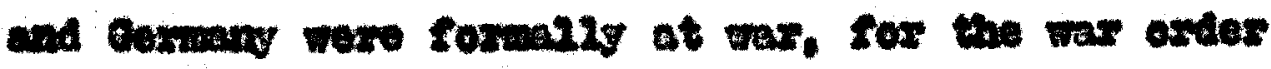

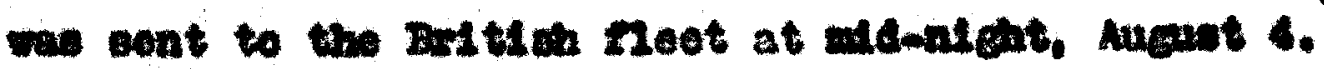

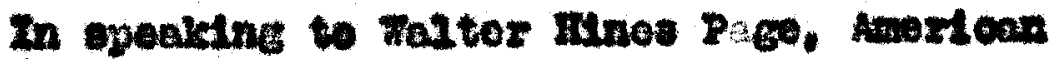
Anbansador at the court of st. James, juet arter the

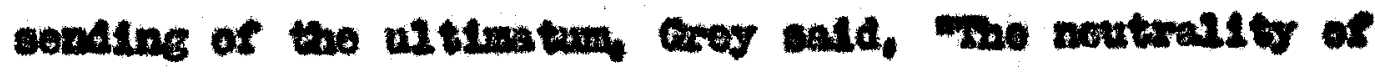
Beletum is aboured by trosty. Cexwany is a of gnatory

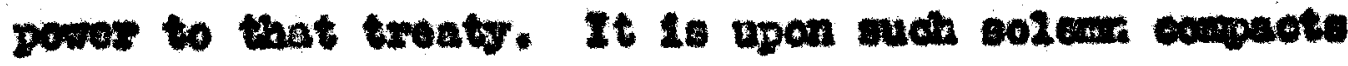

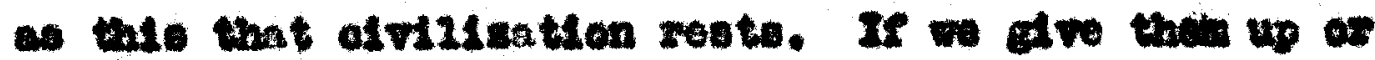

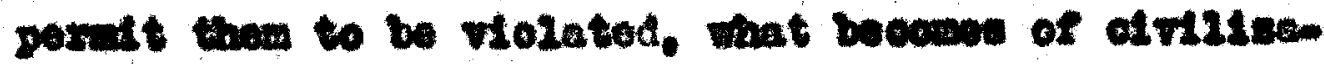

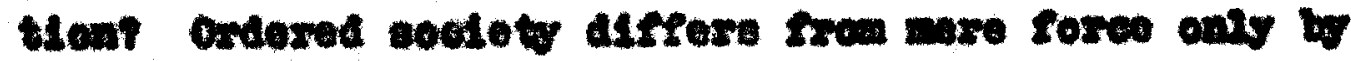

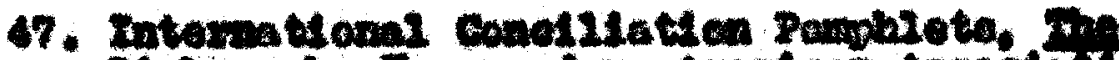

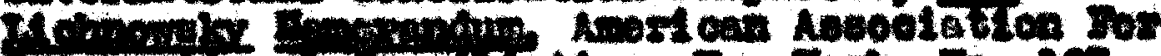

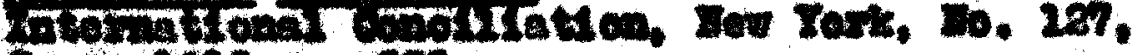
sno, 2019, o, 335,

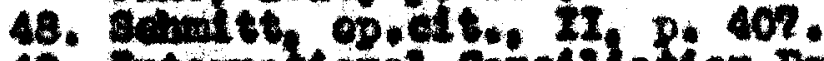

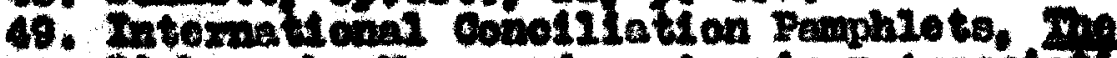

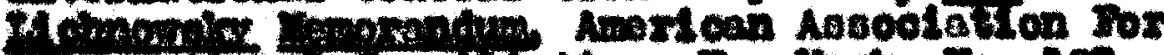

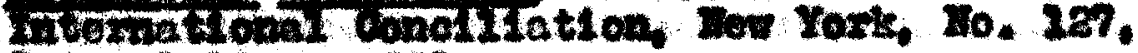
pune, 1928, D. 336.

50. Viscount GreY of rallodon op.cit., 11, p. I8. 
such solem agreements or oompacte. . . It moans the and of Belgtum's Independence. . . Mext w111 come Holland, and after Bolland, Demmark. . Thlo one great milltary power means to annex Belglum, Holland, and the Scandivantan 8tates, and to oubjugate Prance. - . The war party (In Cermany) has cot the upper hand. Thus the efforts of a lifetime for nothing. I feel $21 k e$ a man who has wasted his 11fe..."

Accusations have been brought against Ingland that she entered the war for "belf interest" and not because of the Cermen attack upon Belgtum. Professor Barnes declares that the Intente and Belgiun had known of the German plan of attack since 1906, and that ereat Britaln had been dealing $w$ th Belglum for some years in attempting to convinoe her that Belgetum should allow British troops to be landed on Belgtan s012 to throw back the Invaders. Jurthermore. Barnes ass that Oermaxy offered to otay out of Belgtum if Oreat Buitain would announce her neutrallty. He further declared that the treaty of Iondon did not entein any one of the nations to protect Belgium, but to merely see to it that they, therselves, did not riolate Belglum's 52

neutrallty. He declared that the Cerman orossing of Beletum was a "fortunate subterfuge" used by Grey to

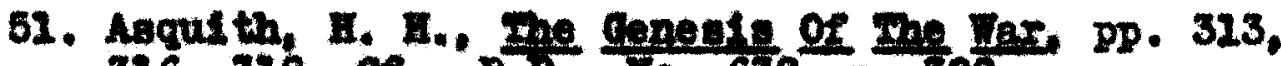
326, 318, CR.. B.5., 20. 638, D. 328 .

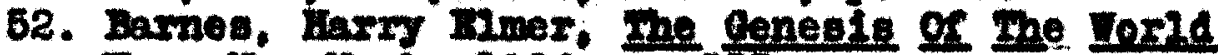
var, Hew York, 1926, p. 565 . 
Inelame Brition public opintion and thus bring her into the war. 53

Professor Renouvin, the Trench hiatortan, save that oreat mitain had docided to enter the war before the Gexwans began the crossing of Bezetwin or even before the cerman vitimature to Belgivm had been delivered. Ho agrees 1 th the American historian, previously quoted, that Great Britain's entry was doctded upon because of the "goneral interests of ringland". 54

At this point it is interesting to examine parts of the memorenda of Dr. Muehlon, unttl the war, a nomber of the Board of Directors of the Krupp works at Fesen. The Dootor declared the speech of the Chancellor wherein he used the expression, "necessity kenow no 2ar". Indieated that Belgtum whout fault. Jurtherwore, the speech showed the strategle ralue of Belgium to Eermans. Inds Mexmen Doctor decleres further, that he had talked with waw wen who knew whereor they upolse and not a single one declared that Beiglum was in the olighteat at favit.

The Doctor continued then with proof to break down the thests that Bergtum expected to attack Hermany. He

53. Ib1a.. p. 679.

54. Ranourin, op. olt., p, 29.

55. International Conalliation Pamphlets, Hemoranda

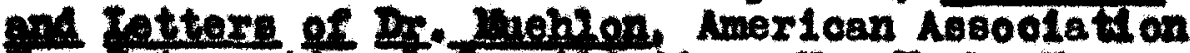

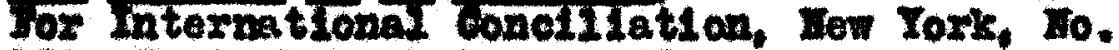
230. Septomber, 2928, p. 495.

56. Told., D. 495 . 
related the story of Belglum's purchase of sour big gane for fortiflcation purposes at Antwerp. Ince the foundat10ne were not eatabllshed for the guns, Krupp, agalnat 2to 121 . was asked to keep these ouns unt11 Beletun wes ready. The latter evon offered to pay otorage on the ams. And 30, Trupp heid the artillery at the outbreak of var, and, of course, the Cerman anthoritles kept the gans. If the Belglans had expeoted to attack Cormany or be attacked by her, wen war threatenod, gald the dootor, undoubtedis she would have secured posseselon of her expenalve gung". The reason that Belgium had dealings of th Krupp, asid the Cerman, was the expreselon of an effort to keep on a friendiy footing wh th cermang". Binoe Dermany is "greedy for business, keen In Its purault, and quick to take offenes", he sald, Melglum belleved that it could keep that country in good humor. - - whereas she expeoted Frence whose Industry enjoyed I1tt2e oupport from the goverment and was, moreover. Iess keen as regarded to lts own development, to underatand her reksons and be content with general indications of aympattrin.

The Germane in October 1914 declared that the Britioh Miltary Attache at Brusgela, Ceneral BarnardLoton, had notified the antef of the Belgtan Ceneral stafe of secret Britiah plano to riolate Belgium's

$$
\text { 67. To1a., p. 501: }
$$


neutrallty if mgland thought 1 t wise to atteck Germary through Belgiva. The story was told by the Belgtan Mnister at Berlin in 1911. Misoount Faldane sav that as 8ecretery of state for Vax, that he (Faldano) was acoused along with the Britinh Ceneral stasf in eponeoring the plan. Viscount Faldane emphatically denies that any plan of the mature was ever auggested, al though ho adidte that the Belgian Ceneral staff was approachod Informaliy by the Britioh nilitary Atteche to ask the Belghans what form of help they would be 1 ikely to noed In case of an attack by cermany. The evidence points, seld the Vlocount, to the faot that the nature of the conversation was largely that of what Britain ought to do In ease of a request for holp Iram Belglum if the latter should be invaded.

It had been cammon knowledge in Bngland for sowe yeare that in the event of war between Irance and Germany that the latter would Invade France by the way of Belgtuid. In the mane fasht on, common opinton Indicated that Roiteln would aotively more to check the Cerman Arug. Al though Bethmann Indicated he was astounded by the Britien ultimatum of August 4, according to the Britioh this was 121 founded because the Germans knew the paxt the british would have taken $1 f$ war had come at the time of the Agadr incident. The military

68. Visoount Haldane, op.cit.. pp. 201-203. 
altuation was escentially the same in each csse. Just as Jrance was entering the Vax, Mrianl and Cambon anked the attitude of crey on her attitude in

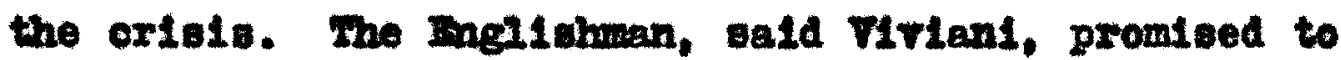
defend our coasts and our flag, by moans of the Britfin Eleet, against all inoults. France, howerer, felt pretty oure by that 1 Ime, August 2 , that aritaln would come to her rescue. Virlant declares that the Mvlolation of Belglan neutrallty made Ingland rise up over the waters, Imovable as desting", Jurthermore, he belleven that even though BeIgtun's noutrall ty had not been rolated that magland would not have remained passive. But, remembering 2870 and observing the marltimo brutal1ty on the part of Cerwaky, Mingland would have taken up the gauge of battze for her honor and her interests".

"The real reason for going Into the war".

sa1d Crey. Wras that, If wo did not 8 tand by Iranoe and otand up for Belgium againgt this aggression, we chould be 1aolated, discredited, and hated; and there would be nothing before us but a miserable and 1 gnoble suture". If Orey were not sinoere in bringing Ingland into bett1e, he was oertalnly good aotor, for, while talking to a friend in the late afternoon of Augugt 3 , he was

59. Oxford Jaculty of Yodern Histoxy. Wy We 슬 At Tas, Great Antain's Gase, oxford, 1914, pp. zi-28.

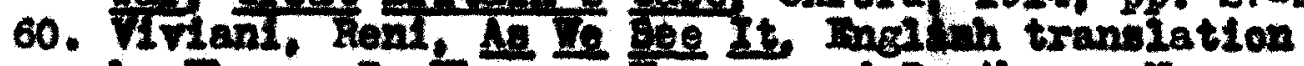
by Momas R. Tbarre, Warper and Hrothers, MeT York, 1923, pp. 225-226.

61. Viscount ger of Fellodon op.a1t.. II, pp. 25-16. 
woved to say as "the laxps wore belng 11t", "The lamps are colng out all over nurope; we shall not see them Itt again in our ilfetime.

W1 thout attempting to defend oreat moltain in her policy. It seems a plausible explanation to av that overy other nation entered the war because of that partleular nation's "general interests". Creat Britain belleved, evidently, that if Belgium hould be wholly crughed, Cermany would welze the entire territory and thus get control of the channol ports. Whe seemed to - 20e1, too, that Ho2land would be the next rictim and the Boandinarian countries would be next in 11ne, not to speak of what might happen to Frence. To this extent, certaing Ingland entered the war in "gelf intereat". Onguestlonably, however, the movement of the German arw acrose Belgtum was a tremendous factor in the British entry in the Dar.

As the war came on, Belghum seemed to steer a course which would have been noutral if Germang had left her alone; but this Germany did not do. And so, the Cerman Army passed over thousands of dead Belgians before 1t reachod Irance. And the time taken to hack their way through this gallant 2ittle country was very preolous to Cermany. For she Iost several days by the military activities of the courageous, petriotie Beiglans, so

$$
\text { 62. Ibld., II, j..20., .... }
$$


much 10, that she found the Brench aruy barring her way to the coreted goaI, Paris; and the Britioh aruy was also setting in line for the fray. Mile on the rastern frontier, the orinous crowls of the Pusetan Bear grew Louder as the Russians gtartied the worid with the rapial ty of thalr moblileation. 
Chapter XII

Japan supports England

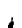




\section{Ghapter xr \\ Japan Buppoxts Inctand}

When Vatther Galbral th Perry, aeting for the Int ted Btaten, broke the barrtera of Japan in 1854, he stimed the hoarts and minde of the Ialand notion to ouch an extent that before the pasaing of atx decades Japan was the most powerful nation of the Jar Bast. Japan had tonsed orerboard many of ber orlental activities, mothods, and attitudes before her positton beoame atrong. She recognized that in many ways the ocoldentel natione were far aheed of her. partloularly along the lines of miltary and asval strength. She sen, too, that madulne wethode wat in maxy Industries oupplant mamfacture by hand. The, therefore, began to study the Destern world w1 the the Ides of taking that wich could be ptilized to the benerit of hex civilization.

In 1894-1895 ahe defeated mina without diffculty. The outcomo of this ilght atartled a large part of the rorid, and caused sone of the nations to 20ok with conoern upon the growing power of whe Iand of the Rulng sun".

Great Aritain had on oovastone prilor to this war

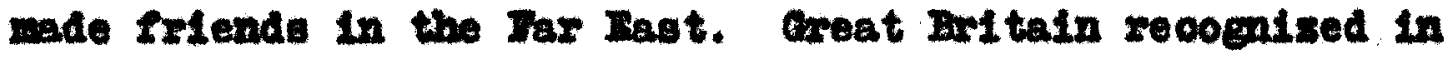
the oloning years of the nineteenth century that poasible trouble could come to her Indlan suplre. 
The suttioh reoognized that China was a tremondounly large oountry and could be of considerable velue to her becauge of the exceedingly long boundery line between culna and India. Iatural2y, therefore, the Britteh begen to cultivete a oloser friendship of th mina. Creat iritaln in 1893 suggested that chins beip proteot siem in the diffloul ty with Irance; howevex, Ghtna refued. Then came the Sino-Japanese war and it th it defeat for Culna. mereafter. Ereat Britein did not beek the minese friench anip. A rery alentefloant turn of affaire came whon mussie, at the close of the war, decided to make objecthons to the requirementio that Japan ade upon china. Ioreover, Aussla was opposed to Japan taktng Port Arthux and oocupy Ing a part of Ianchurle. Mussis saw that Japan might beoome too powerful on the Aslatlo seaboard and al ght interfere with her proposed Trans-81berian ral1roed. A Dusetan prince deolared, too, that if Japan over aet foot upon the manland that she would more as a dxop of 8 011 on a sheet of blottling paper". Mon both Iranoe and Gexzary took misela's alde of the discuselon, Japan was compelled to give up territory that she manted. Ievertholess, Japan accepted the decision of the Powrers with stolc phliosophy. A repregentetive speaker of Japan

1. Chang, Clung-ru, Anglo-Jenanese N11ance, Johns Fopkine Press, Beltimoro, 1931, pp. 12mL.

2. Ghang of ting kosen, I, p. 136.

3. Ghane, op.olt., p. 264 ff., of. Diokinson, p. 279. 
Indicated that peece would not last long. It was his belles that natlons were 21ke merchants in that they week gain and if they fall once they try agaln.

Ingland amounced she would not Interfere when the other Powers cheaked Japan after the 81no-Japanese war. The Kalser considered that amouncewent as $800 d$ diplonacy for sugland. Japan had, in the weantime. adopted both the Alplomscy and milltarlem of the Vest. Both Finglend and Japan agreed that they wight have a cownon enouy in the Jar saat. They, therefore, conoldered an allanoe. The Japanese, however, were at the same

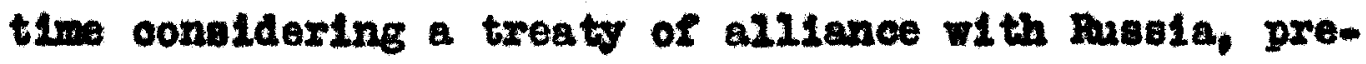
sumably against Ingland, granting to Japan certain rights In Korea, whlle Rusala was efven opportumitios in Ianchurla. The Japanese Cabinet, however, rejected the proposed Russo-Japanese Allanoe and accepted the proposal for anglo-Japanese Allanee, The publioation of the treaty was made early in 2902. The Mllance was renewed In 2905 and again in 2911. The two Powers in the rlwat treaty reoognized that the one had "Bpeclal Interesta" In cuing, the other "opeolal interests" in xorea. In the event of war, where one of them fought another Power, the ally agreed to maintain a strlot neutrall ty". Should any other Power or Powerg "enter the flght . . agalnst that al1y, the other If gh Contracting Party will oome to

\footnotetext{
4. Dicidwoon ol ting Wavaht, D. 104.

5. Ibld.; p. 279.

6. Iold. p. 285 .

7. Dialinson, op.01t.. p. 288.
} 
Ite assiotance...". This alliance was aimed alrectly at Duesta who refused to check her ambltious polloy in the Jax Iast, and this faot, coupled with general condl. tlons, waused areat Britain and Japen to make the NIL. ence.

As a result of the allienoe and pusela's fallure to get out of tanohurla, Japan declded she was able to Give battle to Rusala. This ended in an overwbelning cefeat of hussia and tremendously inoreased the preatige of Japan. Japan uslng western diplomay and miltarlem had defoatod a weatern natlon.

In 2905 the Alzlance was renewed. It was neceseary that either ally come to the support of the other in case another Power should be the aggressor in an attaok on elther Japan or Great Britain. Jor Japan, It was unlikely that fusale would attack hers for oreat Buitain, It was unilkely the security of her temitories In Molatic waters would be questlanod.

Strangely enough, rery soon after the AngloJapanese Aillance was made, the Britieh eame to an understanding with Irance (2904) and with Fusala (2907). ConsequentLy, at the outbreak of the World War, there was wore than a harmonious feeling existing anong the four Powert. 21

8. Chang, op. olt., Appondix A, pp. 282-284,

9. IDLd.i pp. 268-269.

10. Tb1d.: pp. 271-272.

11. Treat, Payson Jaokson, Amert ca And the Ereat For.

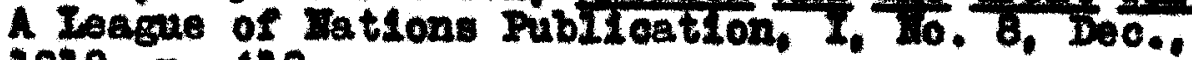
1928, p. 428. 
If 2912 the twe nattons renowed thats alll.

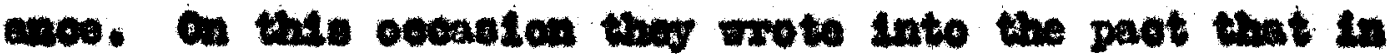
cage Althox of the Hen Contracting Parties oonelude treaty of genoral arbltrotion of th a thind Poner that

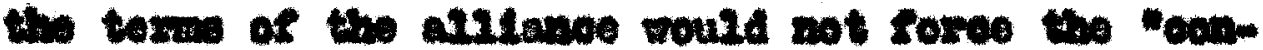

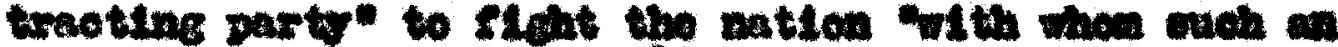

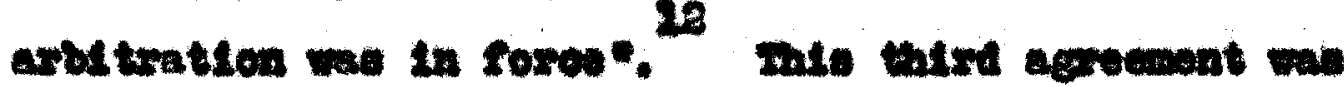

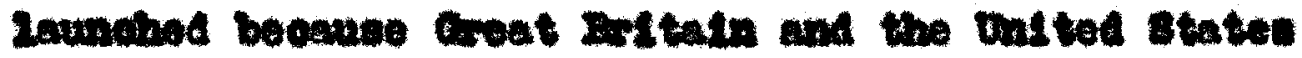

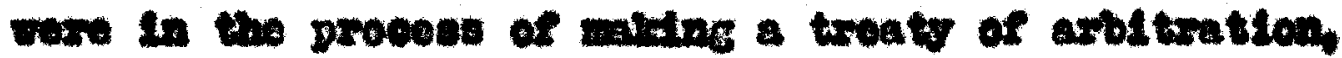

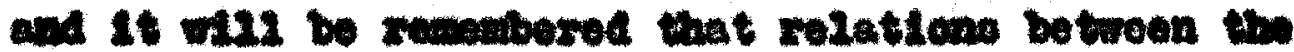

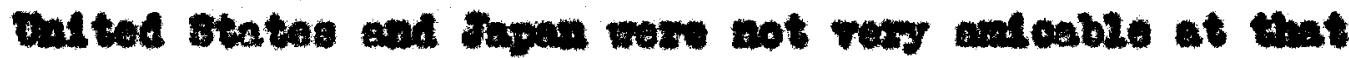

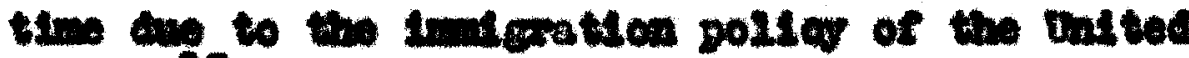
23

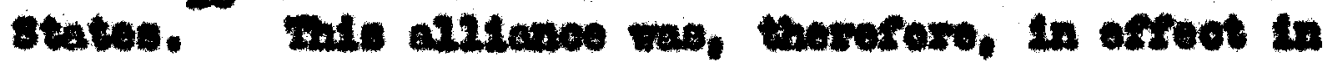

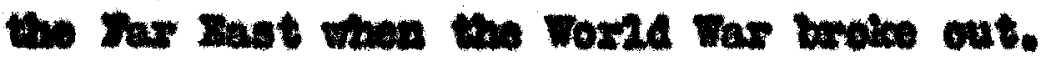

It wae qut te evident to obeervere of the pwo

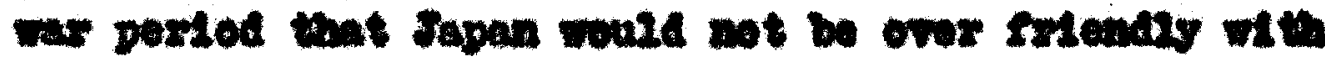

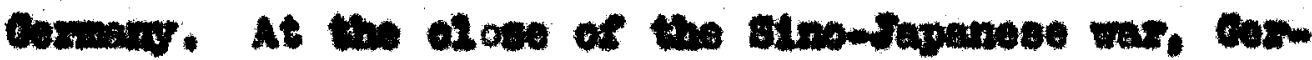

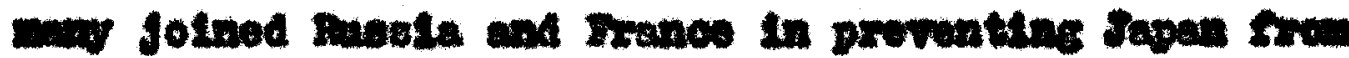

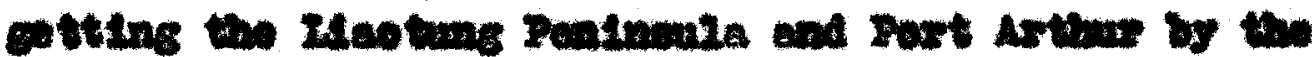

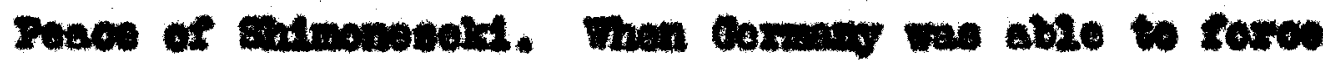

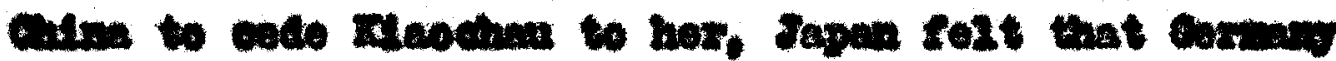

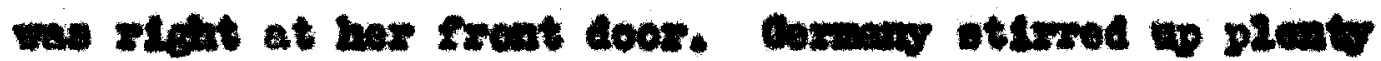

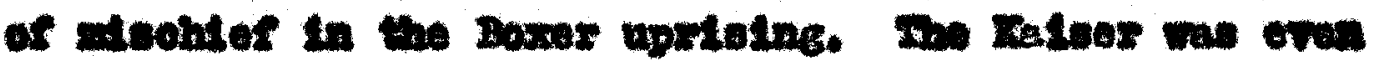

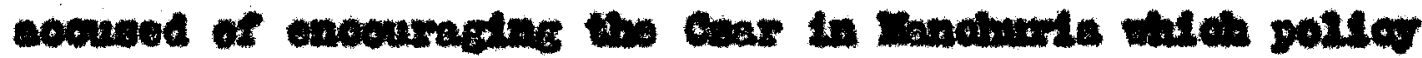

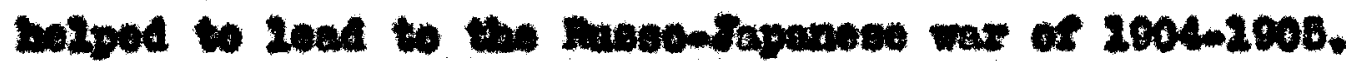

12. Qman, 0p.est, D. 200.

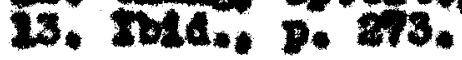


The Ialser, too, had whouted rellow Feril" at the Orfentals ouring the pertod of inoreasinghy tense reiotlons. When cermany began to mate "a strong naval bese" at Iaochail. Dapan naturally began to refleot on the purpose of this base.

As late as angust 1 . It did not oen to str Bdward Grey in Iondon that Jepan would be celled upon to

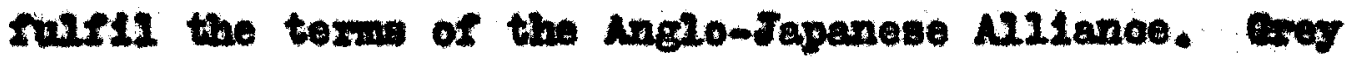
eald to the Brittin Ambaseador at Tokto, . . If, however, we did Intervene it would be on the slde of Jrence and Bussla, and $I$, therefore, Ald not see that we were Ilrely to have to apply to Japen under our alilance 15

- . " " Mowever, on the very next day some of the editors of the press of Japan wero considering the posalbility of the astion enterine the rax. The riempolnt, as expressed, wa that the nation would be ready to fleit for the protection of the orient.

Anguet 3, the British Joreten Inister asked Greend at Toklo to warn the Japanese covermont that, If hootilities opread to the Far Fast, and an attack on Hong Jong or Wel-hat-wel were to take plece, we abould rely on their axpport" if Britain 1seued the call for Japan to stand by the terms of the allanes.

14. Treat, op.01t., gp. 429-420.

15. Exer to Ereens, telegram, August I, B.D., No. 356. p. 266.

16. Exeone to grex, telecram, August 2, B.D., No. 498, p. $27 \%$.

17. Grey to freene, telegran, Mugat 3, B.D., Io. B45. p. 206. 
The Japanese were not long in reaching a declalon. The Iapanese Forelen Mnister notifled the Ir1t1a Ambassador on the same day that Japan, of course, .was not Interested in a Iuropean war. but 15 a cexman attack should be made on Hong Kong, then Fugland may count upon Japan at once coming to the assistance of her aly wth all her strength, If called on to do $00 . .$. . The reason for and nature of the aseistance required" allent be declded by Ingland, be concluded.

On Augupt 15, Japan called upon Cexwang to release Keochan in order that it be eventually given to Elna. Io answer was forthoonting from Cermang al thouch whe was elven eleht dars to think 10 orer. 19 At the explration of that perlod, the Japanese subjects read the - Twperlal Japanese ReBeript Declaring Fer agalnst Germany from noon of Auguet 23, 2924". In 14 Japan vald amone other things, We, by the grace of heaven, Inperor of Japan, seated on the throne occupled by the asme dynasty from time imomortel do hereby wake the following proclam. atton to our oubjects: We heraby declare war againat cermang and we cowmand our arwy and navy to carry on hostilitles against that Baplre with oll thoir atrength 30

- .". Japan secans to have entered the strugg20 whout ingland actualiy aking her to join.

18. Grene to Exr, telegram, August 2, B.D., Mo. 485, p. $27 \%$

19. Ireati op. oit." p. 420 .

20. Told. $\mathrm{p}$. 444, of ting pomment of Imperter Jenar

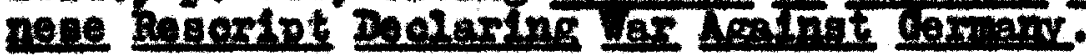


K. K. Ravalcam gre the Tapanese explanation of wh Jepan went to war with Eermany when he sald, In these days when thuropean nat1ons are battLing agelnut one another, all in the name of cod and of the Prince of Peace, it ceems useless to say Japan is essentially a peace-loving people". For 250 years, wh11. Iurope was flehting, Japan was at peace. Japan asd not enter the war wholly because of her treaty with 22

Britain. but becase "germany was a disturbing factor In the Jar Faet and a monace both to chine and herseze". If conoldered the "territorial integrity" of china necestary to Japan. 23 Mnally. Japan dealred that com. meroe Bhould contimie unimpeded. The elimination of german control orer Klapchav would, he belleved, Inoure endurlng peace in the Far Bagt".

Japan, in any case, adhered strictiy to tho terms of her alliance with Britaln. Fere, Indeed, was hor opportunity to strike at The Halled Mst". of the rat. ser's Coverment; here was her opportunity to drive cer. man frem her front door. That she made the moot of these opportundtles, time has revealod in full noasure.

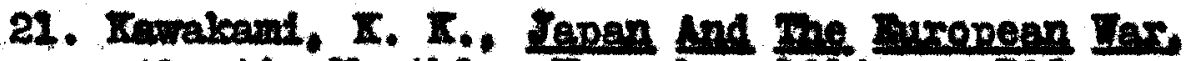
Atlantic Ionthis, Jorember 1914, p. 708.

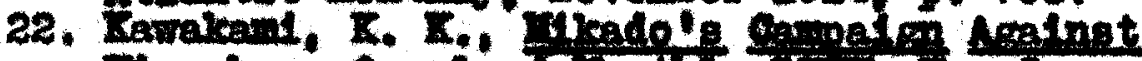

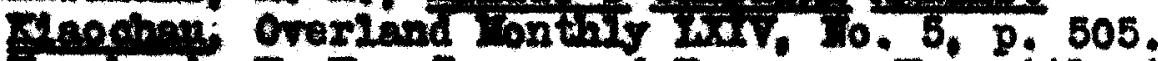

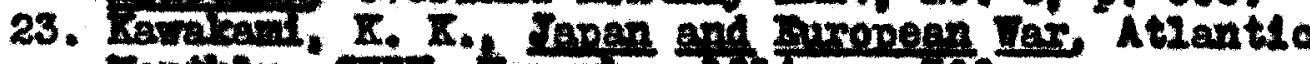
Eonthis, cxiv, lovember 1914, p. 709 .

24. Tbld.. p. 712. 
Chepter XII

Belf-Interest Leads Itely ro Join Bntente 


\author{
Copapter XIII \\ Bezf-Interest Ieads Italy To Joln Intente
}

Then Bliswarak of Prussia set out upon his pollog of mlood and 1ron" to make a "place in the oun" for hla nation, he was pleased to remember that beyond the Alps Iles Italy". But Italy was relatively secure from Invealons from the Jorth because of the barrier of the Alpe. Fevertheless, her enormous coast line did present difficuitles, and, since her uniflestion in 1871, whe was naturalizy interested in the proteotion of this coast Line. Iow Blamarel wes gul te well aware of the faot that Italy was intereated in reaching out for colonles.

When BLwarck was not gulte sure of the reoulto of a proposed Austro-Pruselan war, he invited Italy to join, by offering her venetla. She did not hositate. Both Italy and Prusble were satiafled with the outcome of the struggle.

Both wodern cerman and modern Italy were borm go late in the family of nations that most of the oholee territorles had been chosen. Ievertheless, Blawarak knew that Itely was looking across the narrow strip of water oeparating slelly and the wainland of Africa to a dotec morsel of land decadent in the hands of the descendants of the Noors, namely, Iunis, Ihls could eesliy beoome the colonial star in the crown of an ambitious young nation. 
Iow It so happened that the Gexwan Gancellor lmew that Iranoe had not oompletely satiafled her longlng for oolonfes and that she, too, kept a watehrul eye upon runis. 80 Blsmarck reasoned that should Irence take Tunie, Italy would be angry to see the cholce colonial plun allp through her IIngers. He, therefore, enoouraged Irance "to pluck the ripe Tunisten frutt". It has been sald that BImarck offered this encouragement in order to drive Italy Into an alliance with sustria and Germary. It seems, however, that Blsmarck was primarily interested In enoouraging France. He wished to divert the1r atteation from the mantilation of 1870. In a Iesser measure he was interested in making posalble enemies between the Italsans and the Irenoh. Ie felt sure if Jranoe took Tunis that Italy would be angry. Blamarol was not 1 mistaken.

Blemarol must have known that $\mathrm{Italy}$ would oee In the Irench ocoupation of Iunls a throat towerd Iripoll. Io doubt, ho saw, too, that Italy might fear Irendin propaganda in the Itallen capltal. Bince Irench troops were 1 thdrawn from nome at the time of the IrancoPrugsian war, Italy, no doubt, thought that the Irench weint send their troops back again. If, however, Blemarak knew that as a result of these moves on the Interm natlonal choseboard. Italy would ask that she wight holp form the Triple N11anoe, he gave no sign. As a mattex 
of saot be did not labie ang politely phrsed invitatlons to Italy to join Gerwang and Austria. On the other hand, he oalled Italy"B diplomacy a "Jackal pollog". He declared further that, ". . Italy is inotinotively dran by the odor of corruption and oalant ty always ready to attack angbody from the rear and make off with a bit of plunder".

Blmarck, therefore, advibed Auntria to Irighten Italy. However, the more bo thought about the posalble Itallan ramiflcations with Irance should the Central Powers spura Italy's sult, the Iess he I1ked a possible alsturbance to the balanos of power from that quarter. So Cermeng and Austria were Ilnaliy won over. and the Triple Allianoe was the result. Blomarck was scriooled enough in the gawe of Alplomecy to appreolate the fact that Italy's "gezf-Intereet" seewed to warrant exchanges; that enomies and allles may change almost over night; and those nations who have formerly been fast

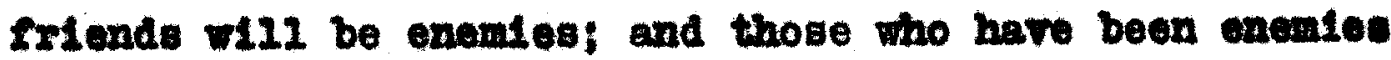
w21 form a apeaking aoqualntenoo again and wonder how 1. was poss1bie hat they ahould ever have oast thelr 10ts in opposite camps.

Austria veems to have been even more wliling than Cermany to make bosom Irlends with Italy fox, in the event Mrstrla over had to flent Rusata, whe did not want to have the Iating to the south of hor to add to hex alfficulties. Austria"s position wes a bit different

2. Buxineon, op.est., p. 82 . 
from that of Cermany for Austrla was a Ioditerramean Power along with Italy. The country of Jrancis Joseph kept her eyes toward posalbie danger in massia and, therefore, was favorable, in the words of one of the Itallan offlofile, In keoping "Italy from the Dooket as long a poseible". "Austria", he contimued, "ooveted no Itallan territory and Italy is not 3 yet ripe for pertlolpation into provinotal ropubilos".

The Itallang now ouggested an alliance with Cexwany and Austria-mingary. The Cermans told Italy that the way to alliance of th her was through Vienna. Votor Inmamul's gotermment wanted to check the amb1tions of Franoe and attempt to re-establiah the "balance of power" whoh had been disturbed alnoe Irance went into Jorth Africe in 1882. Italy deolded whe mist protide for the preservation of peece and the curbing of Iranee 's 2ut for power".

Italy had 21ttle to 208 and mach to gain by an alliance. The was successful in arranglng termo with Cexmany and Austris in a Iriple Allianoe in 1882. Among the terme of the nev IIve year frlendBhip, a Loophole wat Left to Italy. If the other Powers are "attecked". Italy agrees to 80 to thelr ald under certaln conditlens. suppose, howerer, that Italy dectieg one or both of the

3. Diakineon, op.o1t., p. 63, quoting PrIbram, II, p. 4 4. Gosee Polltik, IIt, p. 207.

5. Dickinson, op.oLt., p. 82, quoting Pribram, II, p. 10. 
other mombers of the N1Lance atert the war. In that oave Italy could reserve judoment about jolning thom.. subsequent events at the time of the Noxid War indicated that bo exeratsed this privilege.

Thlo Allanoe gave Italy powerrul srlendo bet 1t was very expenelve, for 1 was necesary for her to keep pece with her oloter stater in making preparation for any diffloulties by enlargling her ard and devel. oping her navy. 1887, however, when the three Powers wet to revise the treaty, whe was able to dewand moxe constderation.

Since Irance had beaten Italy to Iunis, Italy belleved ohe ought to have a rifht to take Iripoll and we so stated that polnt to hor alles. Bhe, furthernore, very modestly alscussed the fistation of the French minioter with hor. for ho ald not hositete to say that. The Koditerranean ought to belong to Jranoe and Italy". After sull and frank disoussion, Gerwavy agreed to stand with Italy in her polley toward Impoll. I0I Blewarok ald not want to see Itaiy and manoe fast frlende, and ho eaw that, should the pro patlons engege In war, Carwany's entrance would be necessary.

It Is highy interesting to note that Italy and Ixanoe by eecret troaty in 1902 agreed to lot each other alone in case elther ranted to develog a ephere of

6. DLaclason, D. 85 quoting fron Iriple Alliance of 1882, G.P.. III, Dp. 245-247

7. Diekinson, p. 87 quoting German Documonts, IT, p. 290. 
Infuence in the territory of Jorth Africa. At the sem tine Itaiy, as a member of the Iriple Allianoe, agreed

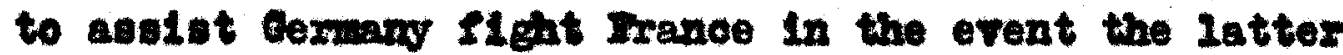
should wake a wore to extend her oocupation or her goveretgnt under any foxw whatsoever in the Iorth ifrican territorles". Ioonmile, Italy asoured Irance that there was nothing in the terms of the Nillance wht ol el ther menaces the securtity or tranqullity of Ixanoe*. 20 It is quit ovident that alliances among states are made largely for gelf-interent and do not necesearlity bring el ther confldence or adnitration. It Io erident that Italy knew about seupinterest.

In opite of the fact that the Iripze MIILanee was renewed from time to time, some of the cermans were not convinced of Itallan almoertty. They thought thay maw that Itely's promise would have no ralue if 1 t wexo not in her Interest to keep 1t. Kiderien Vaeahter Iater declared that, If there should be war, Itely would amalt the outcowe of some of the batties before casting her lot with elther belligerent. 11 rtaly was not decelving Izrolsikl for be declared that if war came, nel ther the IrIple Intente nor the Triple Alliance oould depend an Italy for Italy will then adopt la walting attitude and

8. Dakinson, D. 96 olting Pribram, II, App. $C$.

9. Dicidneos, $p .96$, quoting frem Irtple Milance treaty, hanbe 10.

20. DLakineon, p. 96, quoting Pribram, II, p. 247. 11. DLekinson, $\mathrm{p}$, 98, quoting Pribran, II, pp. 166166. 
then $f_{8}$ in on the alde toward whioh victory is inolining".

At the great or101s in 2924, Italy found herself with treatles of th one or wore nations of both the Iriple Intente and the Triple Alliance. The Itallan Ambassador at Parts disoovered that Russla was favorablo to the Idea of granting Serbla an outiet on the Mdriatle. In a conferenoe with Polnoare, the Ambassador sald that Italy stood ready to guarantee the position of Mlbenis and showid war break out, Austrla would recelve Italy's ald. Polncare countered by saying that was out of harwony with the Iranoo-Itallan understanding in 1902. To the astoniahment of the Irenchman, the Ambastador asld that the Mrbenlan axrangement of th Auetzd a had been made before the Irenco-Itaulan agreenent and, therefore, it vould be mandatory upon Italy to 80 to Austria"s ald. Irance, of courbe, expected Italy to remain noutral in a war between Cermany and Irance. Intarelly, Irance, after this conversation, ald not know just wat to expect fram Italy in cave wat broke out.

It doubtiess was no great ourpxise to the cerreans to IInd the Itallans a 21ttLe blt Iukgwarm an the erents oulminated Into the outbreak of rar. Cermany wat have knom that the friendahtp between Italy and Anstrie was somowhet stralned. Italy and Mustrie each bad

18. Mokinson, p. 98, quoting Mrro I01x, I, p. 266. 13. Dikinson, p. 321, quoting Hirre No1r, $\mathrm{i}, \mathrm{p}, 361$. 
Intereste in the Bajkan peninsula. If Austria fought Berbla, and at the 0lose of the war took some of her territory, It would mean the emlargenent of Austrien power and consequently would be opposed to any ambition that Italy had in the Balkans. Itely, too, was certalniy not Interested in seeing the Adriatio become an Austrian 2ake. In addition, the Austrian Trentino distriot, a wedge ohaped allce of territory composed largely of people of Itallen desoent, Aipped deeply Into tho Itallan Mlps. While the Irfeste district, too, was in the hands of Austria, Italy could never be rery contented. Io doubt, It seemed plaunible to Itely that the way to get control of manrodeemed Italy" wa not to ILght Austrian battlos wniess strong "compensations" would be forthcoming. Cermavy, therefore, was not harboring any 112uslone that the Mllance could expeot very mach in a military way erom 2 taly. 24

In apite of the fact that Cermany knew of the Austro-ztalian diffioultes before the war, ohe tried to hold Italy in 21 ne and to urge Austria to satisfy Itallan demands, Hotom, the terman Ambessador, had been tole bs the Itallan Jorelen Mnister that if Austrie was atteupting to ouppress serblan Mationallam by riolence . . Italy would not accompang hor along thls path". So the German 20st no time in telilng his goverment that bunless Austria comple hersele to reoognize plaimy in fiew of the

24. Renouili, p. R99, quoting Conrad, III, pp. 670672. 
danger, that in case she intends to take anvthing in the territerial 1ine, she w111 have to compensate Italy, I considex the ol thation hopeleas". 28

Fon Jagow had agreed with Austria, July 6, that Italy ahould not be told just whst Mustria had in wind in serbla for be had been in Rome long enonge to under. stand oomething about Itallen characteristios. Theresore, he knew that there was langer to the Nillance in any Austal an morement in the Baikans, Fe feared, too, and rightiy, that a hesitation on the part of Italy to assist Austrila wovid encourage Mugsta with the hope that Itajy wht not even be satiafled with neutrailty and might be pereuaded to joln the Intente. Fon Jagow, therefore urged Henna to satisfy Italy for, eccording to agreenent. Italy could clain oompeneation for and territtorlal changes in the Ballans that is to the adrantage of the Benube Ionaroly.

It seened at flrat, however, that Berohtold was optinietlo weening to think that Italy could not be 80 despleable an alls as to turn against the ronarow". count Eoyos even went so far as to declare that Italy war not ent1tied to compensation. Mfter mach pressure from Berlin. Denna did oonsent to als Italy a Lttle

15. Aortor to jagn, telegran, July 26, 1914,

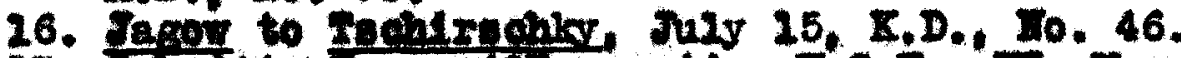

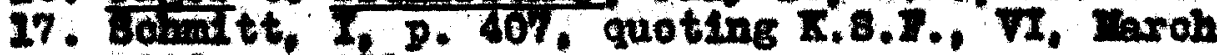
1928, p. 231 . 
conceselon for even the ralser sald, so Berlin declared, that Austria must "cone to an understanding with Iteily on the compensation question in timen. 18 Vema was WIIIng to aay she did not expect to retein any luatrian territory. but might be forces to hold some of the land "during the course of the rar". Bhould this happon, Austrla would discuss "compeneation" wh Italy at a 1ater date. When Berlin heard of this move, whe felt that ahould war come (and 24 was imminent) that the wole alliance 121 begln to totter. 10 berchtold linally oent a statement to Italy raguely stating that she acoepted the Interpretation of the famour Artiole 7 in the A2Lance in comnon Fith Cerman and Italy. provided Italy fulliled the cutles of an al2y".

The contents of the Austrian note, because of 1ts ragueness, proved unacceptable to Italy and, in addition, Italy declared that ang atteupt to help Austria In a war opposed to the Latin's interests might cause the throne to totter. Whe further added that she did not dare to have her coasts "exposed to Inglish oannon". this t1re, however. July 31, Italy was woving toward neutrallty. She went on record aying that "Austria's prooedure agalnst serbla mast be oonsilered an act of aggreabion". A game foederts, according to the Iriplo

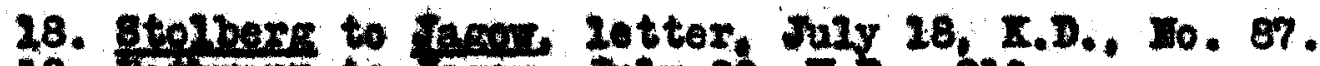

19. Droment to inger. July 29, K.b. 220.

20. Esnouvin, p. 308, quoting biplomatio Papers, III, p. 87 .

21. Pantair Douments, op. oft., Yo. 614, g. 472; 6. 676, D. 601; 110. 745, D. 538 
Nilanoe ald not exlat, 22

Angust 3, Italy losued a proclamation of neutrailty. She, however. Iet it be bnown that if oultable "compengation" was forthooming, she migent rule11 her part of the Allance. Sultable compeneation, cooordis: to Italy. would have been the cession of the Irentino aletriet to hex. Bercintold hare, as in wost othor places, would not nake any concesition. Italy dropped strong hints, a280, that she infent be pereuaded to jotn the Intente. Berahto2d, howerer, could not be pereuaded at this time to make definite offers, for he considered the demands blackmatl.

It wes quite a blow to the Alliance men Italy ald not join them in the war; moreorer they lower they had to treat Italy in a reasonably friendiy fashion in order that who might not aotualiy fight against thom.

rust before the proclamation of noutrallty was

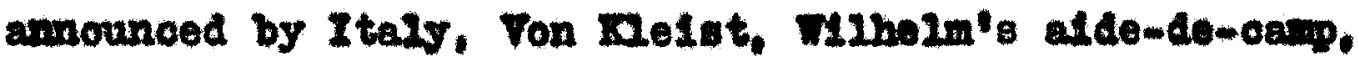
Visted Viotor hamanel for an interview. The cermen reported to his rojal water that the Itallan King ald peraonaly he was opposed to neutrellty. Fut he added, munfortunately he was powerless". The King acreed to attempt to influence his goverwment but eridently ungucoesatuly alnee the pollag of hands off" from the Itallan coversment was almost immediately forthooulng.

22. IbLd.. 10,534, p. 427.

23. Penouvin, p. 3i2, quoting piplometle pavers, III, p. 142 .

24. Fontele posmente, Io. 850, p. 587. 
Iater he sent a wersage to W12hein in which he sald that Italy could not recognize that Aubtria had a oaube for war and that, therefore, she would make use of her AIpl cmatio actirity to the maintenance of the legit1mate Interests of our allies and ourselves in the course of peace". The Itallan $\mathrm{K}$. Tng glgned his note to the Kalser, Tour brother and ally". The ralser, famous for his Interpretations and expreasions, underined "ally" tw1 ce, and wrote on the telegram, "Booundre1, Impudenoe!" In the meantime, the desire to gain the territory hold by Austria, Inhabited by Itallans, becam very popular, There was a divided sentiment, horrever, in Italy. It seems that the press and public largely farored the intente. Mrsolint, at that time relatively young, favored the intervention of Italy on the alde of the Intente nations, As the govermment kept its ear to the ground scmembat olosely, It gradually began to got oloser to the polnt of view of mussolind and others. In the meantime, Italy ras making diplomatio overtures to Austrla for some months $w$ th the thought of strengthening the AIIIance and making arrangement for "oompensations". On March 2\%, 1925, It Beand that the two natlons were getting eloser to an accord. Austrla expreased herself as willing to make a cession

25. Vitterlo Dannele to V12helm, K.D. 755, p. 542 .

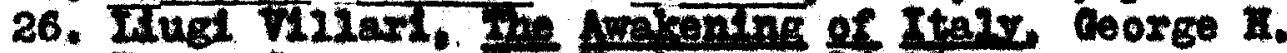
Doran compery, Le Tork, pp. I6-16. 
of territoxy in southern Myrol comprising the of ty of Irent". The offer, however, was a bit rague and was unscceptable in the foxm offered to Italy.

Iegotlations and disoussions prooeeded, wt th relations becoming wore etrained, unt1l Italy submitted "the conditions whioh the Royal Itallan Corexnent conaLders Indispeneable it a normal and enduring of reolprocal cordiall ty and if possible suture oomoperation toward common alds of general polloy is to be created between the two 8tateg". Then followed eleven Artl oles upon which Itaiy rested her case, asking that Austria acree. The conditions were not wholly acceptable to Austria. Rawe, then belleving relations would not 1mprove, w1thdrew from her Allience with Austria, lay 3. 2918.

The Austro-Hungerian Coverment recelved the pronouncewent of Italy's withdrewal with painful vurprive". declaring that this "put an end in auch a sumuary manner to a treaty which was besed on a cownuntty of our wost important political interests whloh has euaranteed security and peace to our respective states for 80 many years and which has been of obrlous beneft to Italy".

27. 8oott. 24promette Bequants, op.01t., (xtallas Green Book, $10,5 8 \longdiv { , ~ p . ~ } 1 2 9 1 .$

28. Ibld.; 10. 64, pp. 1229-2230.

29. Ib1d., Eo, 76, $\mathrm{pp}, 2317-2318$.

30. Ib1d. p. 2320. Ints note did not appear in tho ereen Book. Iranalation from A,R,B.. approved by Itallen mubassy, Mashington. 
Iay 23. Baron Bonnino, Itelian Iinister for Joxilen Affalrs, bent a message to all Italien Beprooentatives abroad and Foirelen coverwonts justifying the position she was taking and ammormolng that on and after lay 24, sho would be in a state of war with Aus tria-iungary.

The Intente and the Cantral Powero had made offers to Italy. Italy wanted territory. She vanted her ationals under the Itallan flog. The Intente won Italy. In the spring of 1915 it appeared that the Intente alofit win the war. Hndoubtedy, the 2atter had - Larger purge and could offer more "alnoe 14 was not Its own goods it mes fiving awa".

31. Tb1d, Unmumbered, Baron gonining to Tteltan Peprogentativeq broed pp. 2322-1328.

32. Diarnson, op, at t., pp. 469-470. 
Chapter XIV

After the study Is Iade 


\section{Gapter XIV \\ After The Btudy Is Iade}

Authors of war ere not necessarily those who declare 1t, but those who make it necessary. The milltary provocetion of 1914 was largely determined by a diplomat10 provocation. The gystem of militariam built up in Murope after the Pranco-Prugsian var, together with the otrengthening of alliances and secret diplomsoy, undoubt edis contributed mach to the outbreak.

It 1s possible, says Dickinson, that marwed anarch produces war, even though a.2 the diplanata be archange1s; . . If It (mar) does not arlse from the obliquity of agente, it must arise from the medium from which they have to work".

Great commotions arlse out of small things but not concerning amal2 things. The spark at Serajero that set the world ablaze was of 1 tself a relatively amall thing. A comotion of such consequences that no stateman could visuallze, arose from 1t. Fel ther can prophets viguallze the length of tine for the world to recover from the appaling disaster. To nation that went to war in 1914. except Fingland, declared at the outbreak why it was flghting. The milstary party seams to have been in the saddle In Russla, Germany, and to a lesser degree, France. When the diplomat vanished from the ocene, the soldier took his place. Only in Bngland did Parliament order the var.

1. Diakinson, op.o1t., p. 37 . 
The people of other nations were not coneulted. Waw pale tho dobt with thetz 21ves, causod by ran burrtod aotton. Do: a var delayed, It is sald, is frequentiy a war aaved. Acoording to the theale of Hontgolas, wo nation lmov at tho ond of the war why 1 thad fought.

If pronouncomanto of otatesean aro belleved, all wro are defenalve; if faoto of peace treatles are coneldexed, almost all are offenalve. For the wowent, oach natlon has all the right on 1 te alde, and all tho vrong 16 found of th tho enow.

The fuertoan boller, announcod later, that the conf2let wao a war to ond war"; and a war to wake the vor24 safo for demoernce". Ald not oech to have appoared anone the Europeano in the oar2y otages of the otrucge. The var wao, in Iarco part, the rooult of fear. Burope micht be compared to a pooder-mogatne in wht en the aroppine of a 21 ghted match, whothor accident or plan, wao praotically oortain to produce a tremendous oonmagram t1an.

The botiming of tho otrugde, moroover, is the condennation not only of tho performers who played thelr parto moll at the outset. But aloo of the Internatlona? anarebs which they reoesved from the past. It appears to

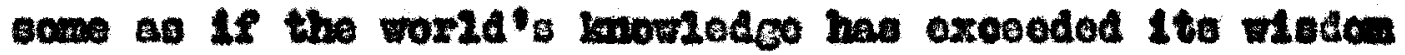

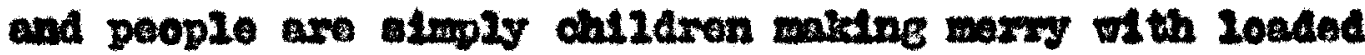
plotole.

Groeting out of this study. the following conclublong have boon roachod: 
I. The natlonalist1c program of serbla would have didmerabered Aus tria-thingary.

2. Austriamungary, to save herself, had to chock the Serbian aspirations.

3. Austria's attempt to check serbla contraxy to Rubsta's Balkan program.

4. Austria-Furgary must, therefore, count on Aussian opposition.

5. In order to meet fussien opposition, Austria depended on her ally. Cermany. Cermany had glven the Dual wonarahy a blank oheck".

6. Both Cermary and Austria-lungary Fere interested in the penetration of the Jear llast.

7. Rusala had an al1y. Trance, that had pledged mil1tary support to Russ1a. In addition, France had a grievanoe against Cermany, namely, the selzure of Alsace-Iorraine.

8. In this maze of conflict, Belglum was brought into the war because whe was in the pathray of the Cerwan arruy.

9. The geographlcal position of Belelum was of great strateglo importance to Ingland. Sho, consequent2y. felt obliged to fight for the provialons of the treaty of 1839.

10. The problem of Anglo-Teuton naval rivalry was becondne intense. Here, perhaps, that rivalry could be settied.

11. Japan gladiy fulfizled her obligations as an ally of Bneland.

12. Finally, Italy took advantage of the occasion to satisfy the irredentlat movement.

To find the causes of the war, the rorld must look at Agadir, then at Mez, and back through Tangter to the Balkan Vars. The Balkan peninoula proved to be the spot where the explosion came. A system brought the war and that system was secret diplomacy, assoelated with natlonaliom, mliltarlam, conmercial supremacy, naval 
supremacy, and ingatiable land munger. History students knew long before Serajevo that strong ties existed among the Buropean Powers. They could, hovever, discover but little of these understandings. They could not learn the extent of the agreements made. They could not fathom the woterles of alplomatic entanglements.

Iren the nembers of the Parliaments chosen by the roters of Burope oould not get accurate information on secret aiplomacy. From the foreion ministers of their respect1ve goverments, editors, c1t1zens, and political leaders attempted to ascertain the exiating tles of the nations w1 thout success. Both requests or demands were anewered with allence or evasion.

The alplomats met in secret chambers and made the bargaing that drove Burope to war. But few of those who went to war or remained at home, knew the methods of the diplanats.

Hations are unquestionably responsible for secret diplomacy. The people who live in lands where parliamentary covernments prevall are especlally responsible for the situation which may cause a great war. People must think for themselves and must not again be deluded by a score or more of alplomats.

In the light of conditions just twenty years after the titanic struggle, evidences point to the poss1b111 ty that it was not a war to end war. It seems orident that as lone as nations arm for war, take 
positlons which war alone can settle, ally themselves for defense, and contimue their secret diplomecy, ware will come and co unt1l at last civilization will falter at the brink of the abyss and w11l af last topple orer and be 200 t.

If peace is to prevall, exceselve nationaliam must be curtalied; secret diplomacy needs to be replaced by open agreements; armaments must be 11 mited by a.1 nam tlons to defensive purposes only, and colonles should be set free when evidencos of self control seem probable.

"The daricsome statesman, ming with welghts of woo IIke a thick midnight fog, moved there so slow, Fe did not otay nor go; conderming thoughts, Ilke sad ec21pses, scow2 Upon his soul. And crowds of crying wi tnesses wi thout Purgue hin with one shout. Yet digged the mile, and lest his ways be found, Worked under ground. Where ho did snatch his proy." 2

2. Diakinson, op.c1t., p. 25, quoting The Forla. 
ExmucoRaptx. 


\section{BTRITCeRnPHX.}

\section{Souroes:}

1. Abquith, Horbert Henry, The genente of the Why Coorge H. Doran Company, Hew York, ISas,

2. Austro-Eungartan Monarchy, Ministertum des $\mathrm{X}$. und $\mathrm{I}$.

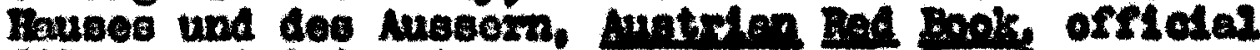

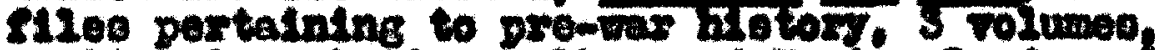

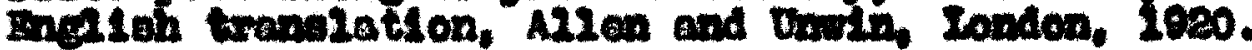

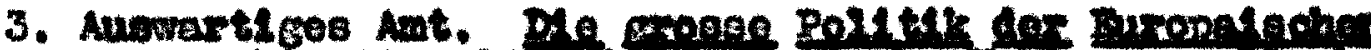

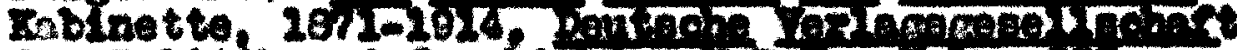

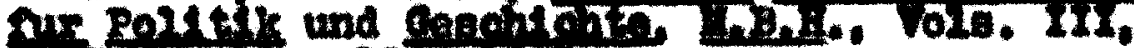

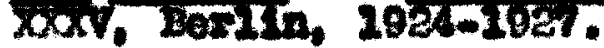

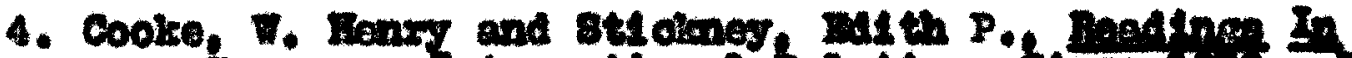

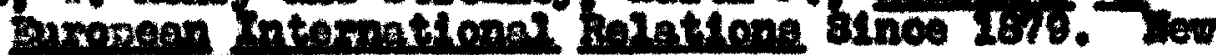
1074, 1034.

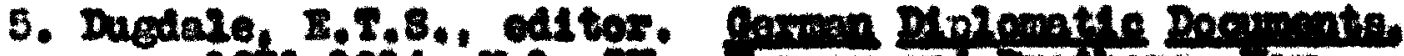
1fin-194. V02. IT. Larpor and wothore, LeV rosk, 1080.

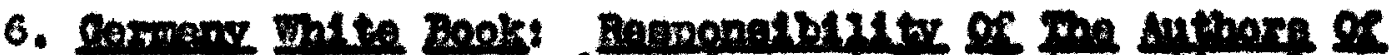

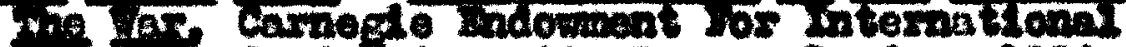
penoe, Oxford Untverel torese, Iondon, 2024.

7. Cooch, O. B. and Iempor2er, Farold, oditore, Butth

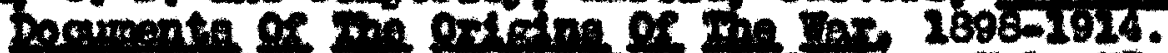

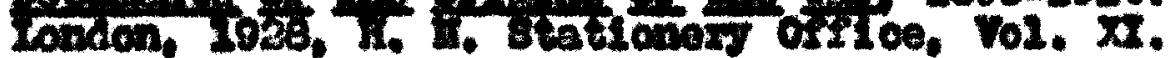

8. International ConoLzLation, The Dechonures Iron

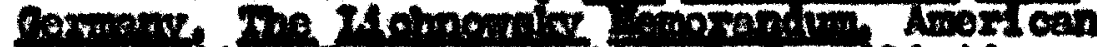

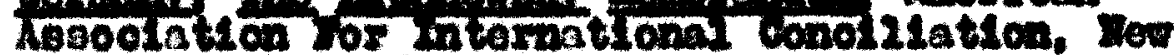
Yoxk, No, 227, sume 1028.

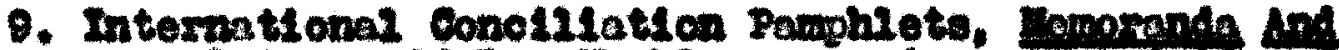

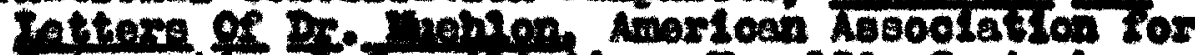
international ionolitation, 30, 130, Beptenber. 1928.

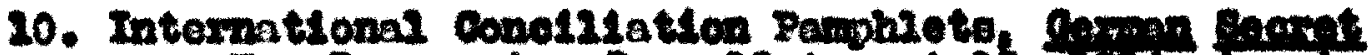

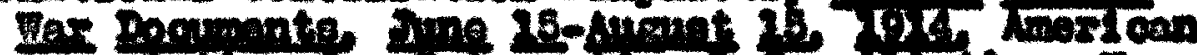

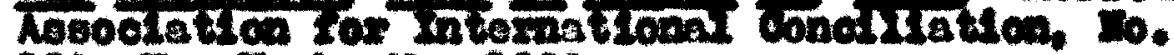
150. Dow Yoris, 2020. 


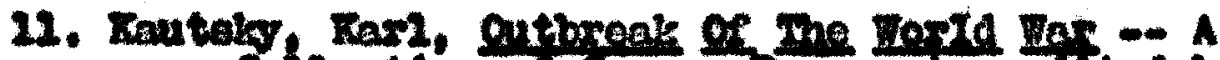
colleotion of tertwan Docurionts, oulted by lax Contares and Vaither solmoking, transiation by Caxpoefe sndownent for Internetional Poace, Oas.

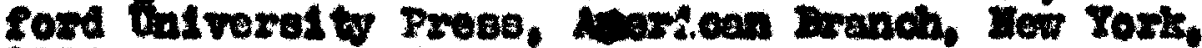
2924.

12. Lambers of The Oxford Jaculty of Fodam Hetoss. Wur

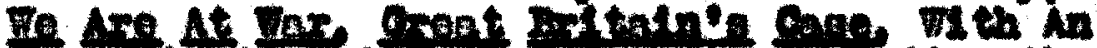
Tppendts of urt glnat boctwonte Inotuding the Anthorlaed Bnelleh Iranalation of the int to Book

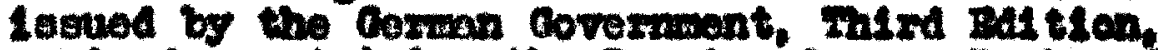
revised, ocktalning the Ruestan Orange Boot ond Extraote from the Delctan Grey Book, Garenden Pross, Oxford, 2924.

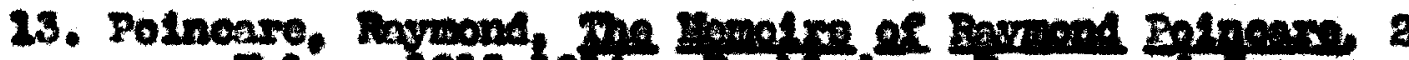

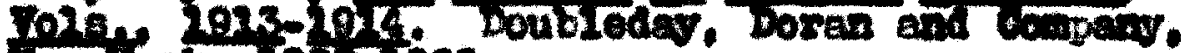

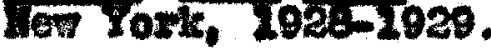

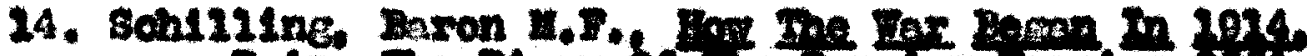

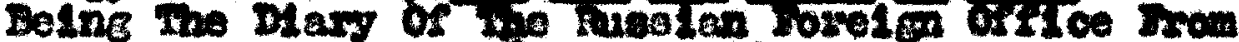

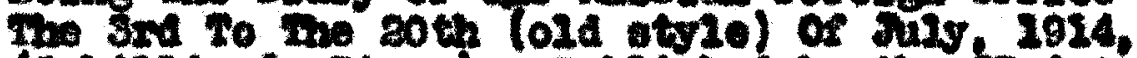

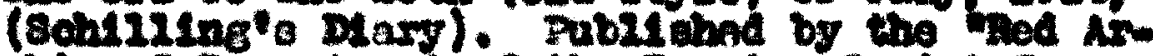
chlvos" Departamt of the Bavelan soviot Corerm-

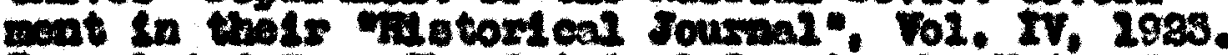

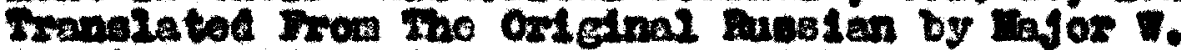

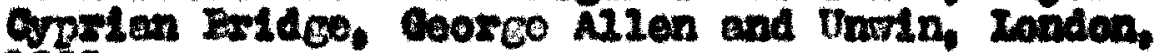
2025.

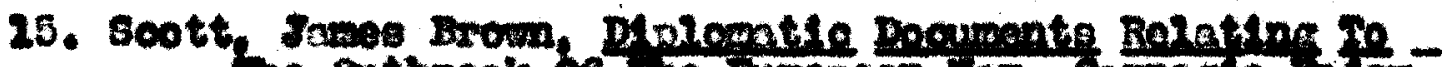

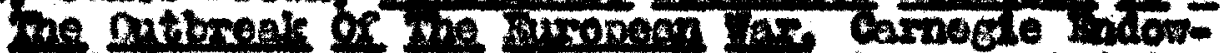
went 7 or intornational P0Q00, 2 volo." contalning excorpto sroat

$$
\begin{aligned}
& \text { a. Tho Dezctan Crey Book, I-Ix } \\
& \text { b. The Brition Tuo Book, I-II } \\
& \text { o. The Jreach Yez10 mook } \\
& \text { d. } 2 \text { no Cerrion inito Book } \\
& \text { a. Tho Itallan Creen Book } \\
& \text { f. The serbian Btue boot } \\
& \text { C. The Bugsian Orange Book, I-II }
\end{aligned}
$$

Oxford univorel to Preac, Nev York, 2920.

16. Hocount Grey of sallodon, menty-7re Yoars, 2892-1016 2 Vols.. Tredort ois A. Btokes boupan, Lor York, 1925.

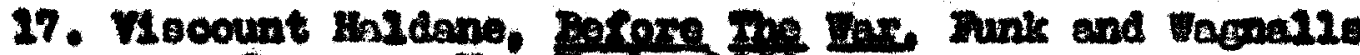

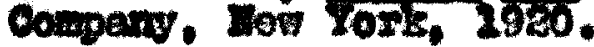

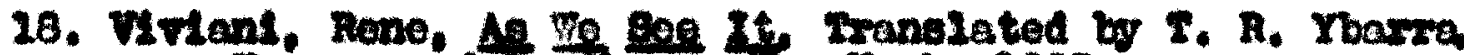

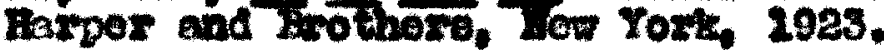


Seoondary Aocounts:

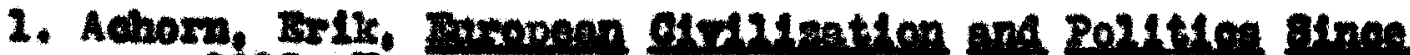

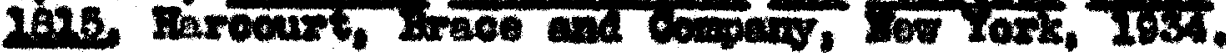

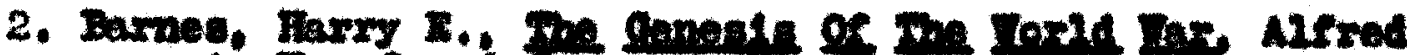

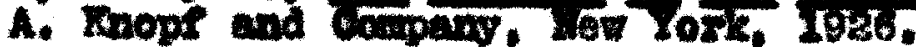

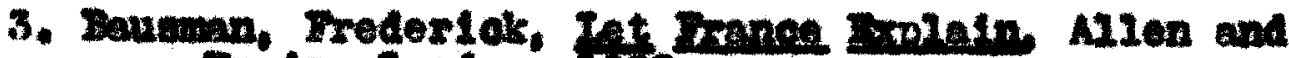
Durin, Ioudon, IVER.

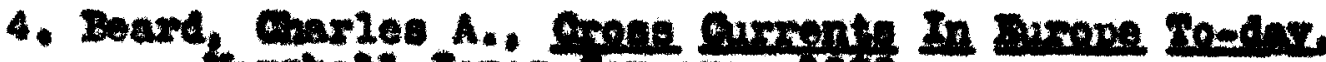
inrobail Jones compan, I92R.

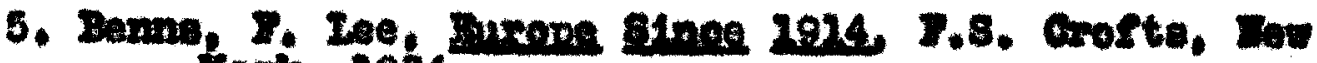
Tork, 1934 .

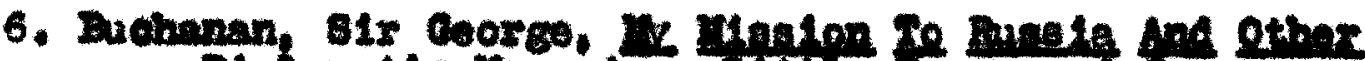

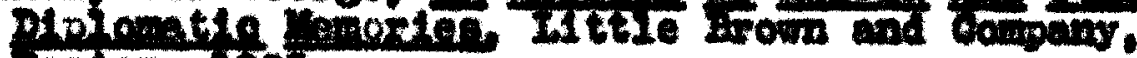
Boeton, 2923.

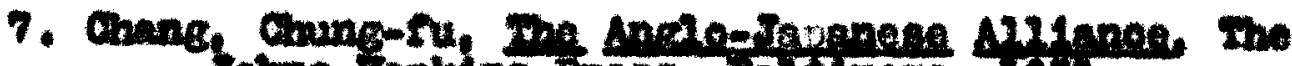
Johne Lopkin Fess, Earxinoro, 2951.

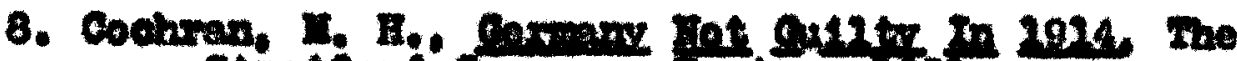
Btratrord coupary. Booton, 1931 .

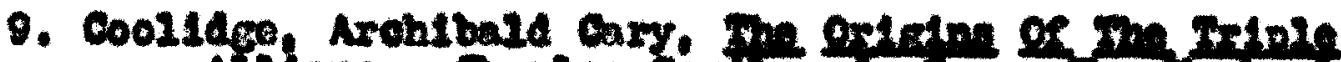

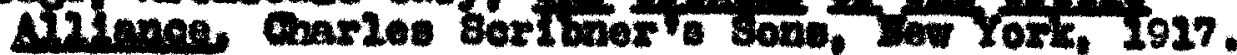

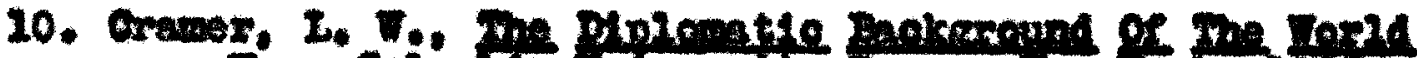
War. Columbia inferstb prose, he rork, 1029.

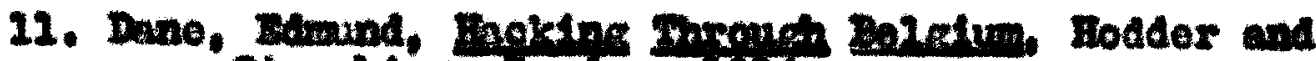
stouginton, London, I9x.

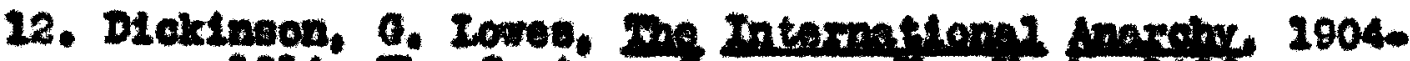
1914, The Contury company, ien York, 1926.

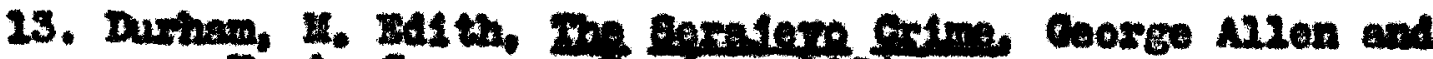
Durin company, London, I034.

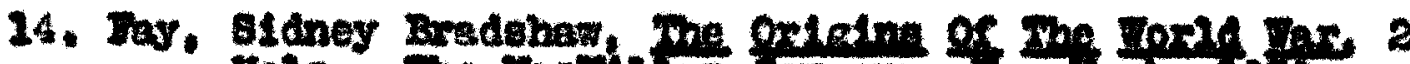

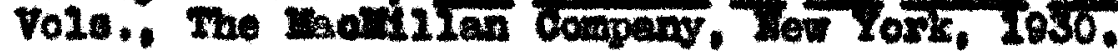

25. Gooch, O. F.. BHatory of Motem Muroge $2878-1929$. Henry Holt and bompany, Les rork.

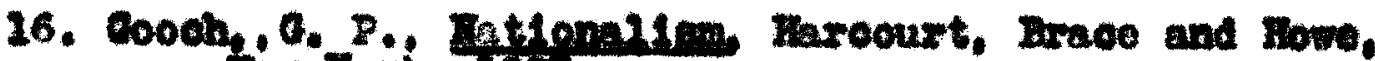
itev York, Iot.

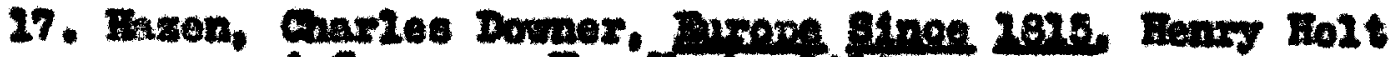
and Company, Dev Tork, I9IO.

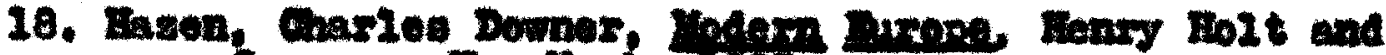
Gempany. Wow York, Iods. 
19. Headiam, J. W., The Migtory of Treire Days, I. Maher Drwin, Iondon, 1915.

20. Iudvig, Bnil, July 14. Transiation by 0. A. Macartney, 4. P. Putnam s Bons, Iet Tork. 1929.

21. Jasz1, Oscar, The D1saolution of the Hapaburg Honarohn, two Univeral to of Chloago Prese, onloggo, 1929.

22. Martin, F1121am, Stateamen of The Far In Betroapect, 1918-1928, Hiton, Balch and Gompan, Iev lork, 1928.

23. Hchon, Georges, The Iranoo-Zugaten A7lance, 187\%1917. Iransiated by Iorman thomas, the Iaconilian Company, Fev York, 1929.

24. Yontgelas, Count Max, The Case of The Central Rorers, AIf red A. Knopf and company, Hev York, 1925.

25. Owen, Robert I., Punstan Impertel Gonge1raor 2892-1924. Robert I. Owen, 1926.

26. Renouvin, Plerre, the Impdiate Origtine of the Dex, Yale University Press, Iew haven, 1928.

27. Roinsch, Paul, Secret Dlplomacx, Marcourt, Brace and Company, rew rork, 1922.

28. Rose, J. R., The Oriatin of The War A.P. Putnam's Sons, New York, 1915.

29. Schmitt, Bernadotte s. The Comping of The Dar 1924. 2 Vols.. Gharles Bcribner's Sons, Vev Tork, 1930.

30. Sohurman, Irederiok Iew1s, For And plolomacy In the

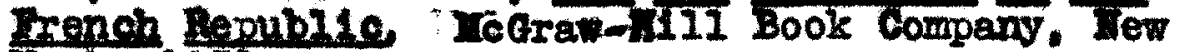
Tork, 1931.

31. Beymour Charles, the Plplaratic Backeround of the Fax, 1870-1914, Taie thiversity Press, Jen Haven, 1916.

32. Steed, Henry Wlokham, The Hapgburs Henarchy, Constable and Company, Iondon, 1914.

33. Treat, Payson Jackson, Amerlon And The Great Ear, A League of Mations, $\mathrm{I}, \mathrm{Ho} . \mathrm{8}$, December, 1918.

34. V11ar1, Iulg1, The Arekening of Italy, The Jasc1 sta Rogeneration, ceorge H. Doran and Company, Hew Tork, 吕o ente.

35. Doolf, Ieonard, Eeonomfe Impertel1am, Harcourt, ixrace and Howe, Wev York. 1920. 
1. Ed1 th Durbom, "The Serajevo Hurder P2ot", Errant intori, Vo1., XXV, D. 650 If.

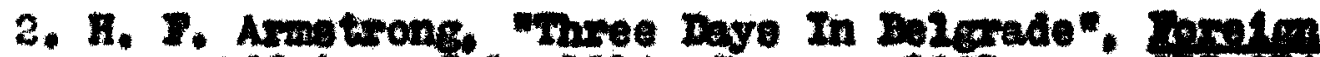
Affetre. Jusy 1914, Jamiary 1927, pp. 21B-214.

3. H. F. Armotrong, Materul Dooumente of 2 wo Worle Nar.. Evrent Ahtory XXv, Ootober 2027, pp. 92-93.

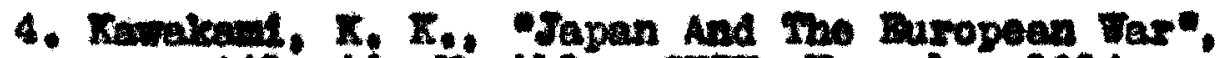
Athentia Entints CxIV, Horeaber 2924, D. 708.

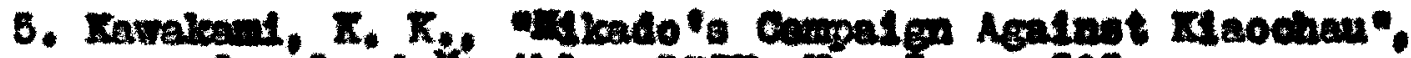

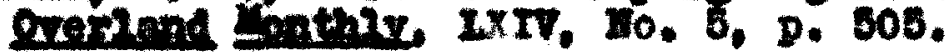

Iowopepere:

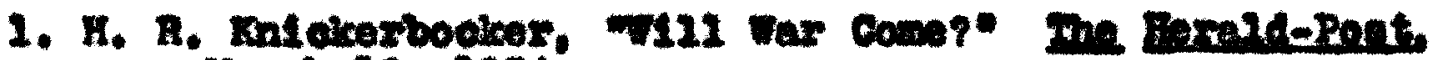
Iarch 12, 2034 .

2. Colonol Fredexioh Palmox, Wvelve Dave that Erogked A

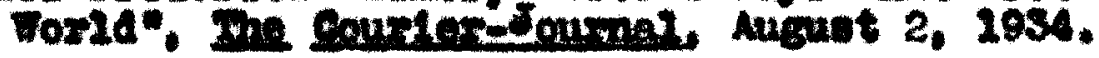

